
Drear Baidi,

- memere of

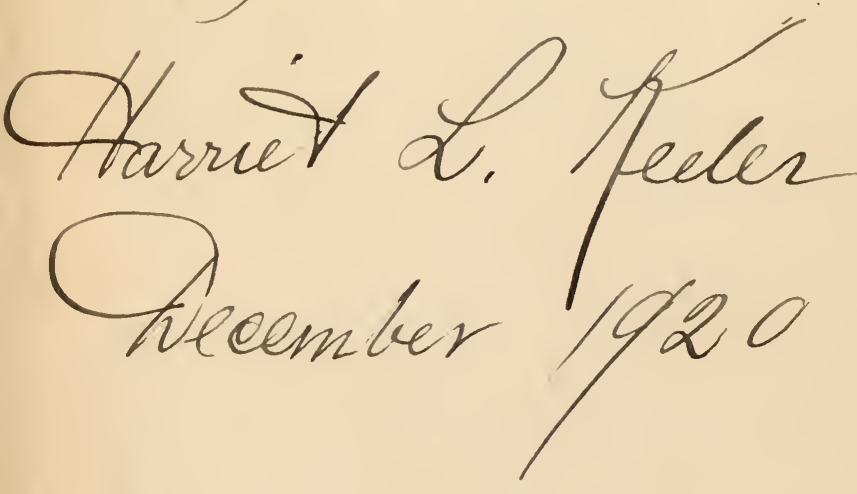






\section{BOOKS BY HARRIET L. KEELER}

OUR NORTHERN AUTUMN

THE WAYSIDE FLOWERS OF SUMMER

OUR EARLY WILD FLOWERS

OUR GARDEN FLOWERS

OUR NORTHERN SHRUBS

OUR NATIVE TREES

Each volume profusely illustrated

CHARLES SCRIBNER'S SONS 


\section{OUR NORTHERN AUTUMN}






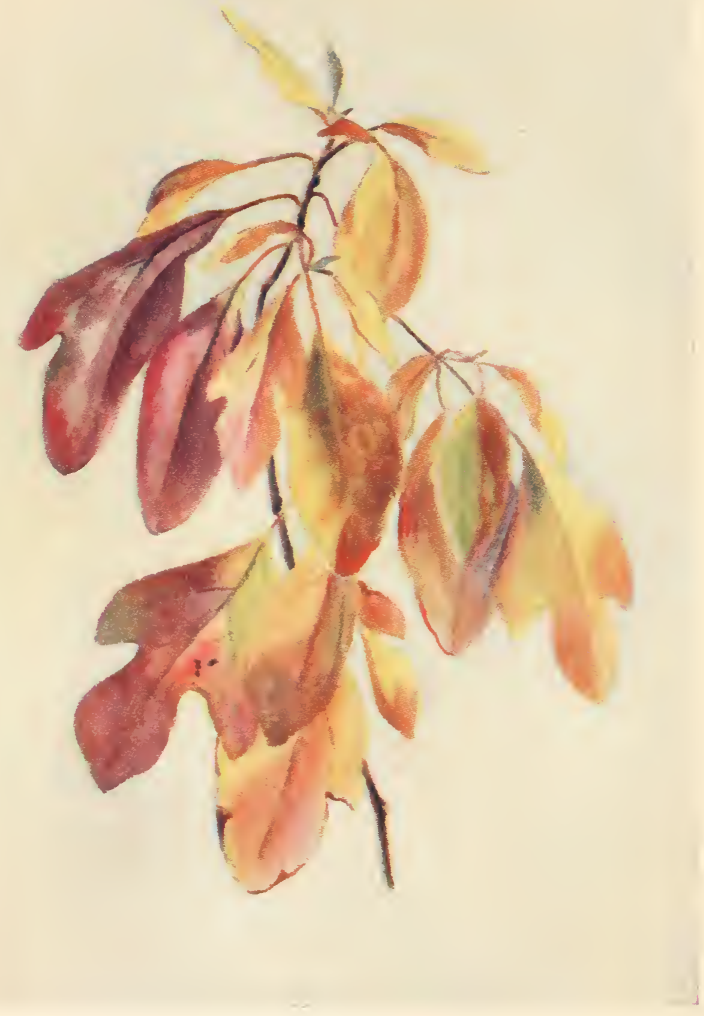

Sassafras Leaves 


\section{OUR}

NORTHERN AUTUMN

A STUDY OF ITS CHARACTERISTIC FLOWERS, ITS BRILLIANT FOLIAGE AND ITS CONSPICUOUS FRUITS

By HARRIET L. KEELER

ILLUSTRATED BY MARY KEFFER

CHARLES SCRIBNER'S SONS

NEW YORK :: : : : : : $:$ I920 
COPYRIGHT, 1920, BY CHARLES SCRIBNER'S SONS

Published June, 1920

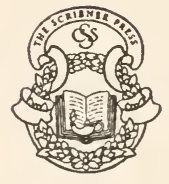




\section{TO}

THE MEMORY OF

HARRIET FAIRFIELD COIT

THIS VOLUME IS DEDICATED 



\section{FOREWORD}

The books of reference for the botanical descriptions are Gray's "Manual of Botany," 7 th edition, and Britton's "Manual of the Flora of the Northern States and Canada.". The photographs are the work of Mr. Carl Krebs of Cleveland, Mr. Nathan R. Graves of Rochester, and Mr. Wilson L. Conway of Milwaukee. 



\section{CONTENTS}

Foreword $\quad$ PGAE

Genera and Species . . . . . . . . xi

Illustrations . . . . . . . . . $\mathrm{xv}$

Autumn . . . . . . . . . . . 3

Descriptions of Autumn Flowers . . . 5

Sturdy Survivors of Summer . . . . . I I5

Autumnal Foliage . . . . . . . . I25

I. The Life of the Leaf . . . . I 25

II. The Color Change . . . . I34

III. Order of Color Change . . . I37

$I V$. Prevailing Colors of Autumn

Leaves . . . . . . I39

October Days . . . . . . . . . . . . 146

The Kindly Fruits of the Earth . . . . 152

Dry Fruits Transported by Their Own

Devices . . . . . . . . . . I59

Fleshy Bush Fruits · . • • . . . 163 


\section{CONTENTS}

Herbaceous Plants with Conspicuous Fruits. $\quad \begin{aligned} & \text { PAGE } \\ & \text { I68 }\end{aligned}$ The Cultivated Fruits of Autumn . . . 172 Nuts . . . . • • • • • • • I7t November . . . . . . . . . . 176 Wild Flower Sanctuaries . . . . . . 183 Index of Latin Names . . . . . . I9I Index of English Names . . . . . . 193 


\section{GENERA AND SPECIES}

PAGE

Aster . . . . . . The Asters . . . . 50 Aster acuminatus . . . White Mountain Aster 67 Aster cordifolius . . . Blue Wood Aster . . 72 Aster divaricatus . . . . White Wood Aster . . 59 Aster ericoides . . . . White Heath Aster . 65 Aster lavis . . . . . Smooth-Stem Aster . 8I Aster macrophyllus . . . Large-Leaved Aster . 79 Aster multiflorus . . . . Dense-Flowered Aster 69 Aster Novce-Angluce . . . New England Aster . 53 Aster paniculatus . . . Tall White Aster . . 60 Aster patens . . . . . . Late-Flowering Aster . 82 Aster prenanthoides . . Purple Drift . . . . 74 Aster puniceus . . . . . Red-Stemmed Aster . 55 Aster spectabilis . . . . Seaside Aster . . . $5^{8}$ Aster Tradescanti . . . White Aster . . . . 62 Aster undulatus . . . . Wavy-Leaved Aster . 76 Lacinaria scariosa . . Blazing Star . . . 84 Nabalus . . . . . . White Lettuce . 85 Eupatorium ageratoides . White Eupatorium . . 88

Composite . . . . Composite Family . . 5

Gentianacee . . . . Gentian Family . . 97 Gentiana andrewsii . . . Closed Gentian . . I I00 Gentiana crinita .. . . Fringed Gentian . . 97 Gentiana quinquefolia . Five-Flowered Gentian 103

Hamamelidace... Witch-Hazel Family . II I Hamamelis Virginiana . Witch Hazel . . . I I I $\mathrm{xi}$ 
Helianthus . . . . Composite Family . 9

Helianthus annuus . . . . . . . . . . . . 9

Helianthus decapetalus . Wood Sunflower . . . 12

Helianthus giganteus . . Great Sunflower . . I4

Helianthus grosse-serratus Saw - Toothed Sunflower . . . . I4

Helianthus strumosus . . Wood Sunflower . . . 12

Helianthus tuberosus . . Jerusalem Artichoke . 15

Heliopsis helianthoides . Ox-Eye . . . . . . . I7

Silphium trifoliatum . . Whorled Rosin-Weed . 2 I

Bidens chrysanthemoides Brook Sunflower . . 24

Bidens frondosa . . . . Beggar-Ticks . . . 27

Rudbeckia laciniata . . . Great Rudbeckia . 29

Rudbeckia hirta . . . . Black-Eyed Susan . . 3I

Helenium autumnale . . Sneezeweed . . . . . 3 I

Verbesina helianthoides . Sunflower Crownbeard I I

Leguminoseæ . . . . Pea Family . . . . 90

Falcata comosa . . . Wild Peanut . . . 90

Moracee .... . . Mulberry Family . . iog

Humulus lupulus . . . Wild Hop . . . . 109

Orchidacefe . . . . Orchid Family . . . 107

Spiranthes cernua . . . Lady's Tresses . . . 107

Gyrostachys cernua . . . Lady's Tresses . . . 107

Spiranthes gracilis . . . Lady's Tresses . . 108

Parnassiace

Parnassia caroliniana . Grass of Parnassus. . I04

Scrophulariace . . . . Figwort Family . . 94

Gerardia purpurea . . . Purple Gerardia . . . 94

Gerardia maritima . . . Seaside Gerardia . 96

Gerardia tenuifolia . . . Slender Gerardia . 96 


\section{GENERA AND SPECIES}

PAGE

Solidago ...... The Goldenrods . . 34

Solidago bicolor ... White Goldenrod . . 4I

Solidago casia . . . . Blue-Stemmed Goldenrod .... . 43

Solidago canadensis . . Canada Goldenrod . . 47

Solidago juncea . . . Y Yellowtop . . . . 35

Solidago lanceolata . . . Lance-Leaved Goldenrod . . . . . 45

Solidago nemoralis . . . Field Goldenrod . . . 38

Solidago latifolia . . . Broad-Leaved Golden-

Solidago rugosa ... Wrinkle-Leaved Gold-

$4+$ enrod . . . . 37

Solidago sempervirens . . Seaside Goldenrod . . 39 Solidago serotina ... Mid-Season Goldenrod 46 



\section{ILLUSTRATIONS}

\section{COLOR PLATES}

Sassafras Leaves .

Frontispiece

FACING PAGE

Asters in Variety

52

Witch Hazel . . . . . . . . . . II2

White Ash Leaves . . . . . . . . . Iq0

Staghorn Sumach and American Elm Leaves . . I50

Bittersweet and Wild Clematis . . . . . 164

\section{HALF-TONE PLATES}

Garden Sunflower

The Great Sunflower . . . . . . . . 14

Great Rudbeckia . . . . . . . . . 30

Early Goldenrod at Home . . . . . . . 36

New England Aster . . . . . . . . . 54

White Wood Aster . . . . . . . . . . 60

Purple Drift . . . . . . . . . . . 74

Garden Form of Blazing Star . . . . . 84

White Lettuce . • . . . . . . . 86

White Eupatorium . . . . . . . . . . 88 


\section{ILLUSTRATIONS}

FACING PAGE

Fringed Gentian at Home . . . . . . . 98

Closed Gentian . . . . . . . . . . . I00

Grass of Parnassus . . . . . . . . . 104

Ladies' Tresses . . . . . . . . . . 108

Wild Hop . . . . . . . . . . . . II0

Butter-and-Eggs . . . . . . . . . II6

Mayweed . . . . . . . . . . ${ }_{156}$

Milkweed Seeding Itself . . . . . . . . I60

Smooth Winterberry . . . . . . . . 164

Greenbrier . . . . . . . . . . 166

Jack-in-the-Pulpit . . . . . . . . . 168

White Baneberry . . . . . . . . I70

$\mathrm{Elm}$. . . . . . . . . . . . $\mathbf{1 7 8}$

Red Oak . . . . . . . . . . . . . 180

\section{ILLUSTRATIONS IN TEXT}

Leaf of Sunflower Crownbeard . . . . . . IO

Leaf of Wood Sunflower . . . . . . . . 12

Leaf of Wood Sunflower . . . . . . . . I3

Leaf of Jerusalem Artichoke . . . . . . . 16

Flowers of Ox-Eye. Flowers of Silphium. Single Involucre of Silphium $. \quad \cdot \quad \cdot \quad \cdot \quad . \quad$. 18 xvi 
Leaf of Ox-Eye

Leaves of Three-Leaved Silphium . . . . . . 22

Brook Sunflower . . . . . . . . . 25

Helenium . . . . . . . . . . 32

Leaf of Early Goldenrod . . . . . . 36

Leaf of Wrinkle-Leaved Goldenrod . . . . . 37

Field Goldenrod, Basal and Stem Leaf . . . . 38

Leaf of Seaside Goldenrod . . . . . . . 40

Leaf of Silver-Rod . . . . . . . . . 42

Leaf of Wreath Goldenrod . . . . . . . 43

Leaf of Flat-Topped Goldenrod . . . . . . 46

Leaf of Canada Goldenrod . . . . . . . 48

Leaf of New England Aster . . . . . . 54

Leaf of Red-Stemmed Aster . . . . . . 56

Leaf of Tall White Aster . . . . . . . 6I

Leaf of Farewell Summer . . . . . . . . 63

Basal and Stem Leaf of White Heath Aster . . . 66

Leaf of Mountain Aster . . . . . . . . 68

Leaves of White Wreath Aster . . . . . 70

Leaf of Blue Wood Aster . . . . . . . 73

Leaf of Purple Drift $\quad . \quad$. . . . . 75 


\section{ILLUSTRATIONS}

PAGE

Typical Leaf of Wavy-Leaved Aster . . . . 77

Leaf of Large-Leaved Aster . . . . . . . 80

Leaves of Late-Flowering Aster . . . . . . 83

Flowers of White Lettuce . . . . . . . 86

Leaf of Wild Peanut . . . . . . . . . 91

Purple Gerardia . . . . . . . . . . . 95

Leaf and Flowers of Ragweed . . . . . . II9

Common Sow-Thistle . . . . . . . . 123

Leaf Venation . . . . . . . . . 126

Stomata, Closed and Open . . . . . . . . 127

Cell showing Nucleus and Protoplasm . . . . 129 


\section{OUR NORTHERN AUTUMN}


If the divine country keeps her due honor in thine eyes. -Georgics, Book I, Virgil. 


\section{AUTUMN}

Autumn stands to us as the period of fruitgathering, of falling leaves, of departing birds, of the slow, continuous, unhurried, and unhurrying march of nature to the rest and quiet of winter.

Officially, summer lasts until the 2 ist of September, but the high crest of summer life is well past in our northern climate before that date and autumn-fall, the Anglo-Saxon word for the closing year-is shadowed forth in early September.

The autumn wild flowers glow in the varying violet hues of the Asters, and the golden yellows of the Sunflowers and Goldenrods modified, varied, and made more beautiful by the white of Asters and of Eupatoriums.

Many of the wild flowers of midsummer live again in late autumn either as left-overs, plants that have suffered from the knife or hoe of the farmer, and, true to weed nature, have snatched 


\section{AUTUMN}

a life from death; or seedlings testing their strength by blooming a little before winter comes; or others whose habit is to bloom sparingly but continuously through the entire blooming season. It is at the very crest of autumn, October, that our deciduous trees, having changed the color of their summer cloak, cast it at our feet, so preparing to meet the slings and arrows of an unrelenting winter. They part from the leaves whose work is ended, they gather to themselves the tiny buds which hold the promise of the coming year, and with all the resources of the tree conserved, they stand awaiting and prepared for all that fate may bring. 


\section{THE COMPOSITE FAMILY}

\section{Compositce}

A flower-head of the Composite Family, the group to which most of our autumn species belong, is really not one flower but a colony of flowers. This colony is circular in shape, its edge protected and usually decorated, all its arrangements orderly, and each individual blossom has allotted space and definite time for its work. The results measured by seed production are so effective that the Composite Family far outstrips in number of recorded species any other floral group in the world.

The illustration, a photograph of a Garden Sunflower, gives very clearly the structure of this flower group and the arrangement of the florets therein. A flower-head is a central disk surrounded by a row of rays, each a separate and distinct floret, consisting of a corolla with or without stamens or pistils. The Sunflower rayfloret has neither. Upon the disk are several 


\section{COMPOSITE FAMILY}

hundred florets arranged in concentric circles, each floret separate and distinct from the others, and each having its own corolla, which is tubular, its own stamens and pistil exactly as any flower that grows upon its own stem. The only part which the crowding of the florets affects is the calyx. This is so greatly changed that one may easily conclude there is no calyx at all, but certainly there are the remains of one; as a matter of fact, the calyx and ovary grow together and only the border remains separate. This in the Sunflower shows as scales or points, which early disappear, but in the Asters and Thistles it appears as the soft white down which buoys up the seed that the wind may carry it away, or in Bidens as the sharp teeth which cling to the fur or wool of animals that the seed may get transportation. Each floret is aided and protected in the struggle for life in some fashion.

After the flower-head is well opened there are florets in four clearly defined stages of development: next to the ray-florets will be seen a circle of open five-lobed corollas from which 


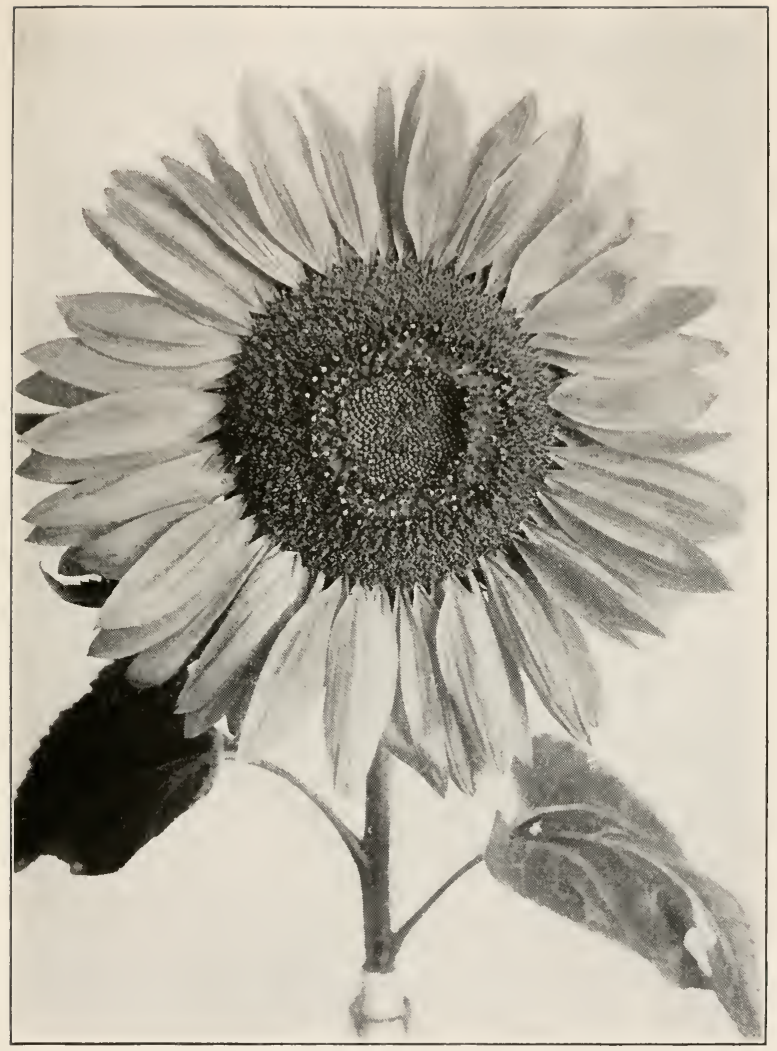

Garden Sunflower. Helianthus ámnuus 
both pollen and stigmas have disappeared, and the fertilized seeds are growing toward maturity; next comes a circle of florets two or three deep, where the curved stigma lobes protrude from the anther tubes, and within that circle is another where the pollen is being pushed out of the anther tubes, while at the centre are the buds. While the hundreds of florets are developing the rays continue strong and vigorous, giving the honey-call to the bees, and they do not collapse until their work is completely done, which is not until the last disk-floret has bloomed. It is possible to estimate the length of life before a composite-head by noting what stage of bloom the disk-florets have reached. If floret buds are few the rays will soon collapse. The fruit of Composites is called a seed, but it is really an akene, that is, a dry shell with a single seed within. The Garden Sunflower is typical of this entire floral group of Radiate-Composites, scmetimes called the Thistle Family.

The characteristic flowers of September and October belong largely to this group, though of 


\section{COMPOSITE FAMILY}

course there are also Gentians, Gerardias, Grass of Parnassus, Lady's-Tresses, and last of all Witch Hazel; these with many summer survivors contribute their part to the sum total of autumn glory.

Of this Composite group the Goldenrods, Asters and Sunflowers are they who brighten our roadsides and transform our fields into a gorgeous pageantry of blue and gold. With this army of youth and beauty march full abreast many lingerers from summer's ranks, though there are many whose title to citizenship is as clear in September as it was in August. Many of these, likewise, are Composites, so speaking broadly we may say that the autumnal, herbaceous, flowering flora belongs to that order which by its efficiency as well as its youth has gained a dominant place in the world. 


\section{THE SUNFLOWERS}

The Sunflowers of the garden are mostly hybrids and variants of Heliânthus ánnums, together with a few wild species which have been subjected to culture and selection. Those of the ficlds and roadsides are largely made up of Helianthus, the real Sunflower; Heliopsis the near Sunflower; Silphium the tall Sunflower, and Bidens the two-toothed, which in one of its forms stands out as a very brilliant member of the group. In addition we may include Rudbéckia laciniàta bearing flower-heads three to four inches across, and distinguished from its companions by its slightly drooping rays and its cut leaves; the lowest five to seven cleft, the uppermost three-cleft or undivided. The leafy monumental stems of Elecampane often appear among the Sunflower group and the plant may well be reckoned as one of them. The popular name Sunflower includes all of these. All are of the Radiate-Composite type. The 
fruit of each is an akene with various attachments.

Among this group of "Sons of the Sun" stands the slender three-leaved Coreopsis, Coreópsis tripteris - which has wandered eastward as

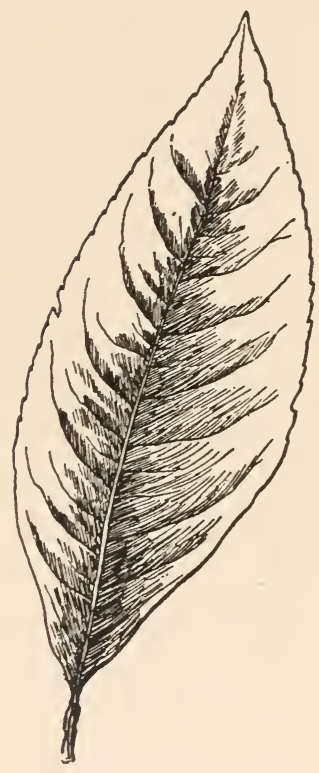

Leaf of Sunflower Crownbeard. Verbesina helanthoides. 4 to 6 in. long far as Pennsylvania and is not uncommon in northern Ohio. A true Coreopsis, its flower-heads differ very little from those of the garden forms except that the ray-florets are oblong instead of wedge-shaped, and the disk-floret a purplish brown. It stands in the tangle five to six feet high, spreading its flower-heads above the press of its companions into the light of the sun, moreover, it possesses the fragrance of anise. Still another spe- 


\section{THE SUNFLOWERS}

cies, Sunflower Crownbeard, Verbesina helianthoides, may be grouped with these well-known and attractive plants. In roadside thickets of Ohio it stands four to six feet high companioned by the Sunflower group, its flower-head a trifle smaller than the others, and marked by its globular disk of dark yellow florets. This disk in fruit becomes a very perfect little ball, bristling with winged two-toothed akenes. The rays are clear yellow, about three-fourths of an inch long. The stem is always four-winged by the decurrent bases of the alternate leaves. This is a determining character. The plant is not so beautiful as the Sunflowers proper, but it is sufficient to add its quota to the joy and beauty of the season.

All the Sunflowers are interesting and beautiful plants; in autumn we may hope to find them upon every roadside and in every thicket tangle. They do not contribute so greatly to the yellow of the season as do the Goldenrods, but they have a beauty and dignity quite their own. The books record many species, but these well represent the type. 


\section{COMPOSITE FAMILY}

\section{THE WOOD SUNFLOWERS}

Heliânthus decapétalus. Heliânthus strumòsus

$H$. decapetalus. Native, perennial by branched, sometimes thickened, rootstocks.

Stem.-Slender, glabrous or nearly so, branched above, two to five feet high.

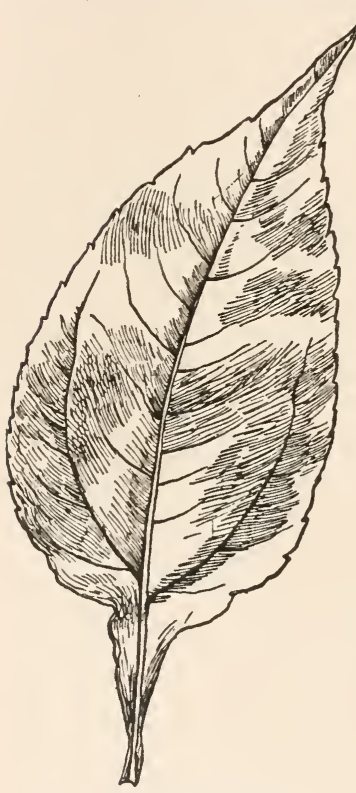

Leaf of Wood Sunflower. Helianthus

Leaves.-Ovate or ovatelanceolate, the upper often alternate, three to eight inches long, one and a half to three inches wide; rough above, of ten downy beneath; acute or acuminate; regularly serrate; the rounded or truncate base decurrent on petiole; three-nerved at the base.

Flower-heads.-Several; rays eight to fifteen. Found in moist woods and along streams.

H. strumosus.-Native, perennial by branched, sometimes thickened, tuberous rootstocks.

Stem.- Glabrous below, sometimes glaucous; three to six feet high, branched above. 


\section{THE WOOD SUNFLOWERS}

Leaves.-Ovate or ovate-lanceolate, opposite, or upper alternate, three to eight inches long, one to two inches wide; rough above, somewhat downy beneath; acute or acuminate; sparingly serrate or entire; decurrent more or less on the petiole; three-nerved at the base.

Flower-heads.-Several; rays five to fifteen. Common in dry woods and on banks.

The two Wood Sunflowers are so similar in general appearance, the book descriptions so nearly identical that it is scarcely worth while for an amateur to try to discriminate between them. Both love the half shade of the open wood, and, standing in numbers where their bright faces are flecked by

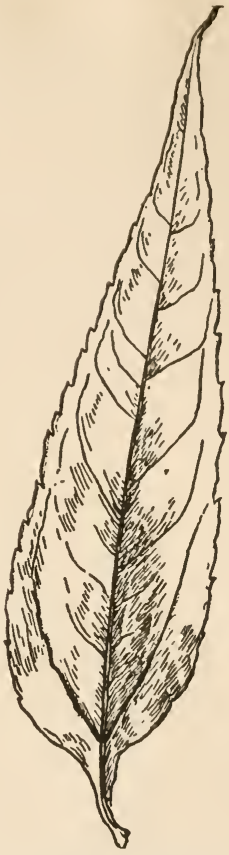

Leaf of Wood Sunflower. Heliánthus the sunlight that filters through the leafy cover, they light up the woodland floor with a soft yellow glow. If a road runs through the wood they crowd to the fence-line, adorable in their 
untamed beauty and vigor. $H$. decapetalus is to be looked for in wet woods, $H$. strumosus in dry ones, though sometimes they change domiciles after the manner of plants. Helianthus divaricàtus, the Rough Woodland Sunflower, has very spreading leaves, rather thick and rough, and enjoys the same habitat as the two others.

The Great Sunflower, Helianthus gigantèus, common in swamps and wet meadows, reaches the height of ten feet, and overtops its companions. The stem is rough, the leaves lanceolate, mostly alternate. The heads are usually several on a stem and long-peduncled. The flower-heads are about two or more inches across, and the rays number from fifteen to twenty. Bracts are narrow, pointed, and spreading. The Saw-Toothed Sunflower, Helianthus grosseserràtus, is scarcely distinguishable from giganteus according to descriptions in the books, save that the stems are smooth, purplish, and glaucous. The leaves are lanceolate, alternate, serrate, and acuminate. One prefers swamps, the other prefers open spaces. Both are noticeable 


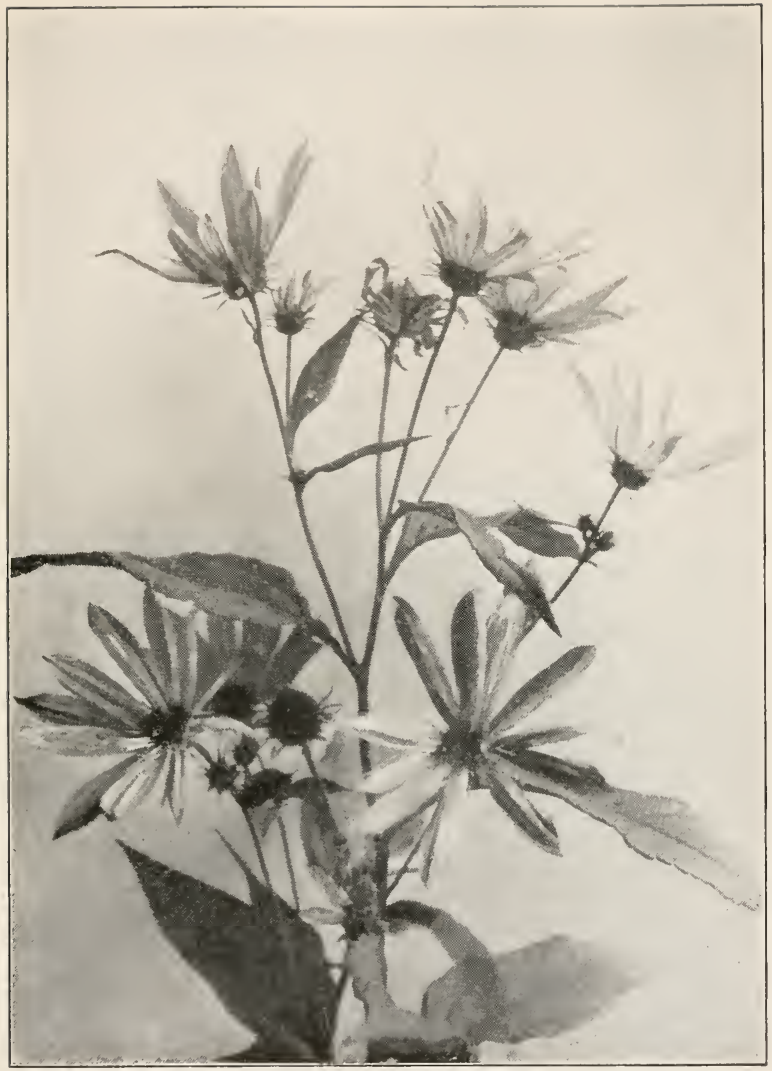

The Great Sunflower. Helianthus gigantèus 



\section{JERUSALEM ARTICHOKE}

plants, both rise considerably above their fellows. Other Sunflowers have larger heads and are more beautiful plants.

\section{JERUSALEM ARTICHOKE}

Helianthus tuberòsus

A native species once grown for its edible roots, now running wild along fence rows and roadsides. Prefers moist soil; the rootstocks produce edible tubers. Maine to Georgia, west to Dakota and Kansas.

Stems.-Five to ten feet high, stout and rough-hairy, branching above.

Leaves.-Four to eight inches long, ovate or oblong, rounded, truncate or heart-shaped at base, serrate, more or less three-nerved, acuminate, rough. Usually opposite, sometimes the upper ones alternate; rather long-petioled.

Flower-heads.-Golden yellow, two to three inches across. Rays eight to twenty. Disk-florets yellow.

The Jerusalem Artichoke is a trustworthy Sunflower, it will do well under adverse conditions, its tubers give it a strong hold upon life. The history of its common name, Jerusalem 


\section{COMPOSITE FAMILY}

Artichoke, is interesting since the plant is by no means an artichoke nor has it the remotest

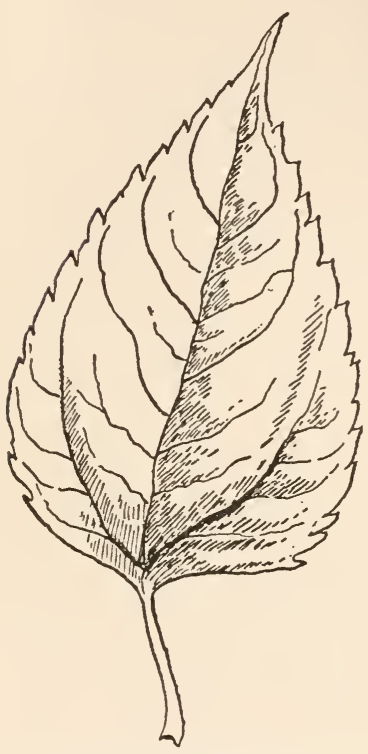

Leaf of Jerusalem Artichoke. Heliánthus tuberósus. 4 to 8 in. long connection with Jerusalem. The creeping roots produce in autumn a number of irregular tubers which are edible and have the flavor of artichokes. The plant was introduced into England in 1617 , from the Farnese gardens at Rome under the name Girasole Articocco, the Sunflower Artichoke.

The Anglo-Saxon genius for changing names is here exemplified, and Girasole soon became Jerusalem, and

so it has remained. The plant is becoming valuable to landscape-artists who deal with large spaces and broad effects. It not only will remain 
where it is put, but will increase and multiply, sometimes far beyond its owner's wishes. This is one of the plants found in cultivation by the Indians, who valued it for its edible tubers, which are fleshy and sweet and very good food. If one wishes to be rid of the plant, a few swine given freedom among them will finish the task.

\section{OX-EYE. NEAR SUNFLOWER}

Heliopsis helianthoides

Heliopsis, Greek, like the Sun.

A very beautiful Sunflower growing in open places and blooming in middle July, which has been transferred to the garden and is now offered by dealers under the name of Heliopsis Pitcheri. Canada to Florida, west to Illinois and Kentucky. Perennial by rootstock. July-September.

Stem.-Smooth, three to five feet high, branched above.

Leaves.-Opposite, or rarely in three's, three-ribbed at base, broad, ovate-lanceolate, rather thin, acute or acuminate at apex, rounded or truncate at base, and 


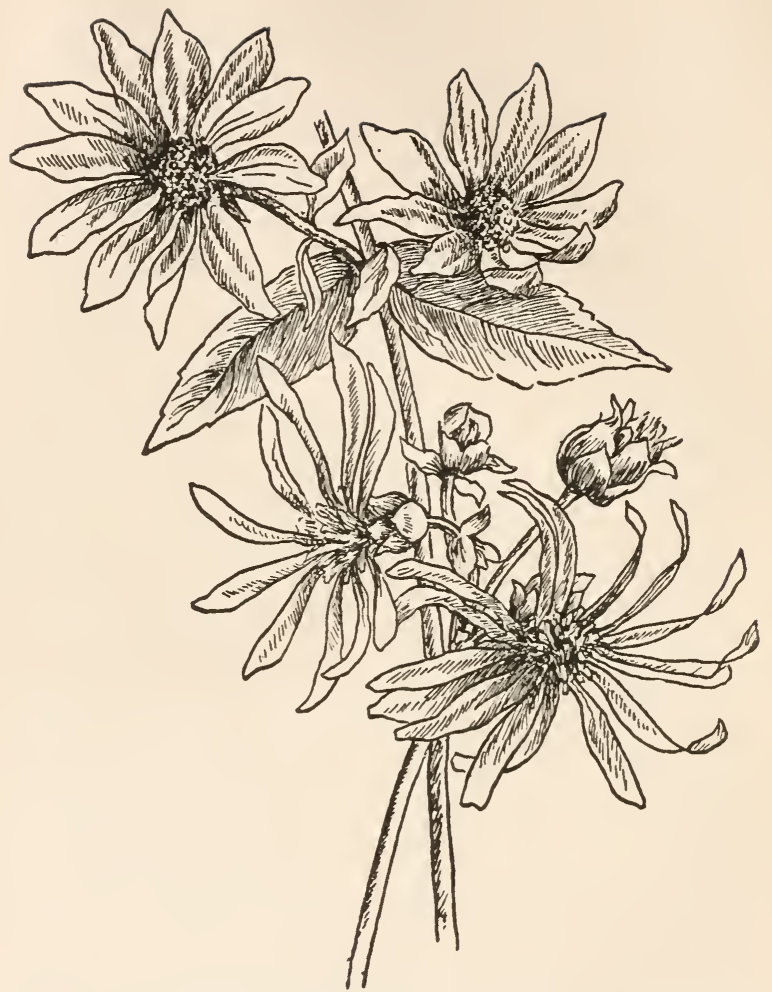

Flowers of Ox-Eye. Flowers of Silphium. Single Involucre of Silphium 
then abruptly narrowed and decurrent on the petiole, sharply serrate, three to five inches long.

Flower-heads.-Golden yellow, showy, borne on long peduncles, which are rather corymbose in arrangement, one and a half to two and a half inches across; rays, eight to twelve; pistillate, fertile, spreading, rather broad.

Fruit.-Akene without attachments; sometimes with a minute coroniform border.

$\mathrm{Ox}$-Eye is one of the earliest of the wild Sunflowers, for it is found abundantly in July. A

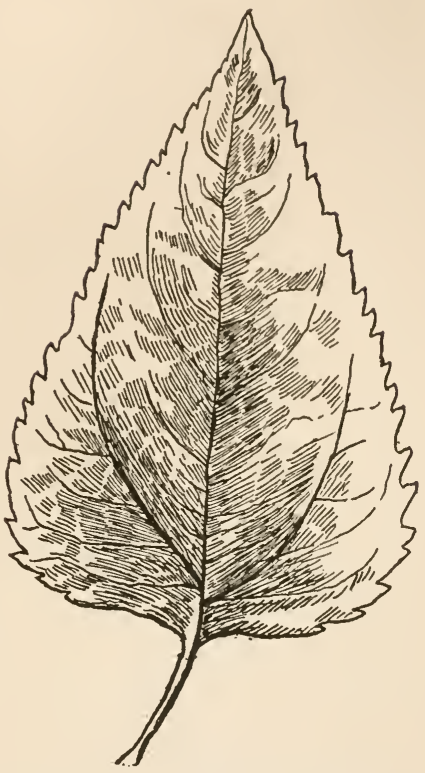

Leaf of Ox-Eye. Heliopsis helianthoides. 3 to 6 in. superb golden yellow, each stem bearing several flower-heads, it of ten appears in such numbers as to dominate for a space the roadside pageant. Careless of 
dust and danger, it crowds so near to the paths of man that it suggests a wildling longing to be petted. It has indeed made its welcome way into the garden, and holds its own there amid flowers of high degree.

This is not Helianthus, the flower of the sun, but Heliopsis, the eye of the sun, and never was plant more sympathetically named. It looks like a Sunflower, it is even prettier than a Sunflower, but it is not a Sunflower; the horticultural difference between the two is negligible, but the structural difference is considerable as such things go. Curiously, this turns mainly upon the service and usefulness of the ray-florets. The ray-floret is a very necessary and essential thing in the economy of Radiate-Composite flowers-it is the herald, the bugler who calls to the passing winged world to come and enjoy nectar and pollen without money and without price. The ray-floret of Helianthus performs this service admirably; it stands by until the last disk tube has opened, but it does nothing more, it matures no seed. But if one wishes to 
see what the ray-floret of Heliopsis accomplishes, take a rather mature flower-head, carefully remove the bracts of the involucre and at the base of each strong, beautiful yellow ray will be found a fine, plump, full-grown akene; thus the ray-floret renders two services instead of one. The books state the facts simply; the rays of Helianthus are neutral, those of Heliopsis fertile.

\section{WHORLED ROSIN-WEED. SILPHIUM}

Silphium trifoliàtum

Silphium, Greek, named because of its resinous juice.

A tall, perennial, Sunflower-like plant, with large, yellow flower-heads borne in corymbose panicles; found in fence corners, open fields, and roadsides. Middle West and southward; not reported from New England, where its place is taken by Silphium perfoliatum, escaped, the books say, from gardens.

Stem.-Three to six feet high, growing in clumps; smooth, often purple with a plum-like bloom, corymbosely branched at the summit. When broken gives a resinous juice and pleasant fragrance. 
Leaves.-Three to seven inches long, lanceolate or oblong-lanceolate, acuminate at apex and narrowed at base, entire, wavy, ruffled or dentate at margin; rough

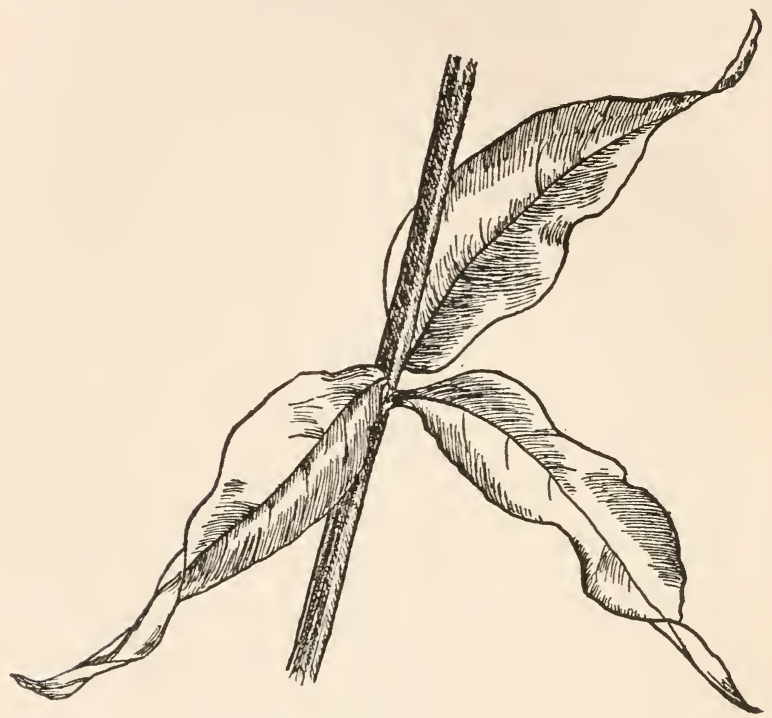

Leaves of Three-Leaved Silphium. Stlphium trifoliàtum. 3 to 7 in. long

above, smooth or pubescent beneath. Alternate, or whorled in threes or fours.

Flower-heads.-Yellow, two and a half to three inches across. Rays linear, fifteen to twenty, pistillate and fertile. Disk-florets perfect but sterile. Involucre of 
a few broad, green bracts imbricated in three or more rows, the innermost row membranous. Akenes are flat, winged, and two-toothed at the top. Only those of the ray-florets produce fertile seeds.

Silphium appears in the wayside tangles of northern Ohio in company with the Milkweeds, Sweet Clover, Catnip, and Wild Carrot, and begins to flower in August, continuing throughout September. Its tall stems are well clothed with long, stiff, dark green leaves, sometimes alternate, oftener in whorls of three or four.

The flower-heads are borne on branching stems which apparently start from the summit of the plant stem, making a whorled or corymbose inflorescence. In the very centre of this whorl of stems rises one, short, erect, unbranched, bearing a single flower-head, the first bloom and of ten the largest of the flock.

The plant has the height and poise of the Sunflowers, though the rays are narrow and the involucre quite different. Only the akenes of the ray-florets are fertile, the disk-florets masquerade with both stamens and pistils, but pro- 


\section{COMPOSITE FAMILY}

duce no seeds that will grow; the style of the pistil is undivided, which perhaps explains the anomaly.

\section{BROOK SUNFLOWER. BUR MARIGOLD. \\ BIDENS}

Bidens chrysanthemoides. Bidens lievis

Bidens from bis and dens meaning two-toothed, in reference to the seed-vessels.

Native. The annual Brook Sunflower in great numbers along ditches and lowlands gives the most brilliant yellow of the autumn. Massachusetts to Ohio, south to South Carolina. August-October.

Stem.-Smooth, much branched, one to two feet high.

Leaves.-Three to eight inches long, opposite, lanceolate; midrib prominent; serrate, acuminate at apex, sessile, sometimes perfoliate.

Flower-heads.-Numerous, borne on short, erect peduncles; two to two and one-half inches across. Rays eight to ten, neutral, broad, very showy, golden yellow, oval to oblong, obtuse. Disk-florets, perfect, fertile, yellowish or brownish. Involucre hemispherical; outer bracts linear-oblong, pointed or spatulate, leafy, 


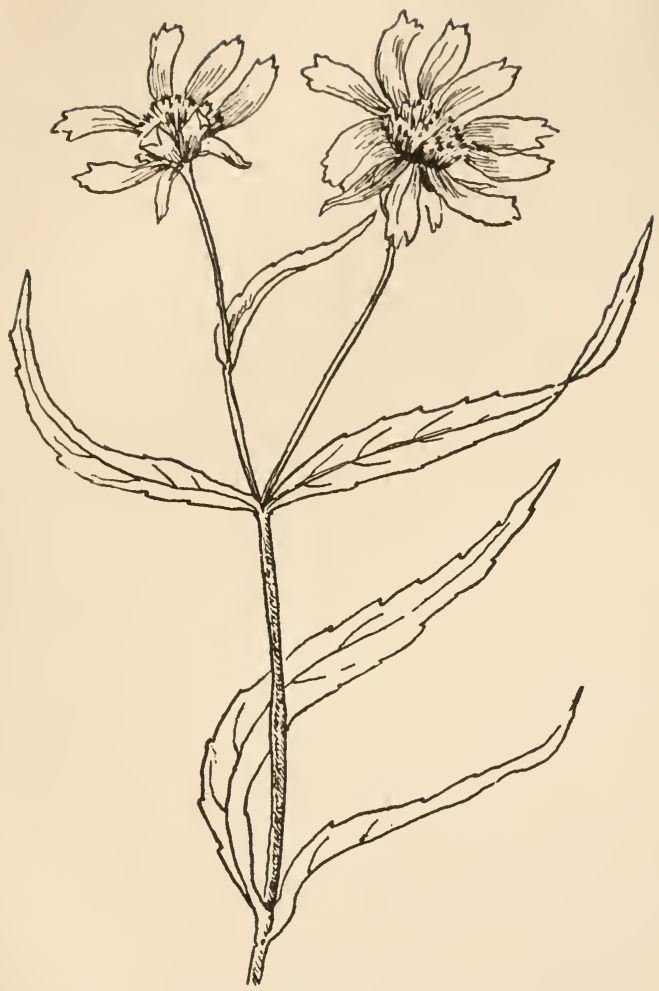

Brook Sunflower. Bidens chrysanthoides. Bidens lèvis 


\section{COMPOSITE FAMILY}

twisted and flaunting, equal or exceeding the broad, brownish inner ones. Akenes wedge-shaped, armed with two to five, stiff downwardly barbed awns.

"The windflower and the violet they perished long ago, And the briar-rose and the orchis died amid the summer glow;

But on the hill the golden-rod, the aster in the wood And the yellow sunflower by the brook, in autumn beauty stood.

Till fell the frost from the clear cold heaven as falls the plague on men,

And the brightness of their smile was gone from upland, field, and glen."

-William Cullen Bryant.

The Brook Sunflower is more at home in New England and in New York than in the Middle West, though common in northern Ohio. In its chosen home along swampy runlets at the border of lakes and ponds it glows in the landscape like a flaming fire. In full maturity it outyellows the Goldenrod, outflames the midday; it is the most direct, the most insistent, the most compelling of all field and roadside yellows. This is not only because it is a marvellous color, but in addition it frequently covers large areas of lowlands with its closely set bloom that runs along a brookside like a conflagration. Not- 
withstanding all its beauty it is a bad weed, for it belongs to the Bidens clan. All the Bidens are free riders, and well equipped to cling to their steeds. The heart of this superb golden flower conceals an arsenal of weapons, an armed group of flat akenes, each provided with teeth barbed like fish-hooks, that they may ride to success and safety on two feet or four. Two others of the genus are in the ditches, but they have no beauty to make us forget they are always armed against us. We call them Spanish Needles, Sticktights, Beggar-Ticks, a General Nuisance, but they do not mind. The most common is Bidens frondosa, the other found mostly in moist places is Bidens connata. Both are dusty, rusty weeds which should be exterminated.

\section{SPANISH NEEDLES. BEGGAR-TICKS}

Bidens frondòsa

Annual. A common plant of the roadside ditches usually one to four feet high, much branched, bearing pointed three to five parted 
leaves, and in August inconspicuous. Composite flower-heads at the summit of stems and branches.

Stems.-Two to four feet high, more or less stained with purple, often entirely dark.

Leaves.-Opposite, compound; leaflets oblong-lanceolate, sharply serrate, acuminate. Upper leaves often undivided.

Flower-heads.-A quarter to half an inch across. Ray-florets few or wanting, yellow. Disk-florets brownish yellow. Involucre hemispherical, leafy; outer bracts often longer than the inner ones. Akenes flat, rather wedge-shaped, dark, margins hairy; the two awns with downward barbs.

Bidens is a militarist and always takes the fighting chance. It is indeed a weed of the ditches, rises well into sight in July, blooms abundantly in August, but makes no particular impression upon anybody until its seeds are ripe in September, when the involucre that has protected the tender florets and growing akenes finally gives way, forms a circular brown platform, and upon it rests a cluster of little armed warriors, the hope and promise of the plant. 
Each warrior bears iwo bayonets, sharp and barbed, ready for instant use, and quick to fulfil their destiny, which is to seize upon any travel'er, human or animal, who can be forced to transport these seeds upon his coat. We have all carried Spanish Needles from their native ditch to a comfortable resting-place, where, more or less impatiently, we removed and scattered them. We supposed we were attending strictly to our own business, but like the bee seeking pollen or nectar, our business fell in line with a great cosmic law, and we served the plant as well-we sowed its seeds. We were expected, for when the floret was still in bud the barbs were provided for, and each and every one was a prophecy of our coming.

\section{GREAT RUDBECKIA}

Rudbéckia laciniàta

Named in honor of Professors Rudbeck, father and son, predecessors of Linnæus at Upsal.

Native. A tall perennial herb with alternate, divided leaves and showy, Sunflower-like heads 
at the summit of the stems and branches. Found in low grounds and wayside thickets. Quebec to Manitoba, south to Florida and New Mexico. July-September.

Stems.-Smooth, branching, three to seven feet high. Leaves.-Smooth or roughish, the lowest with five to seven cut or three-lobed leaflets; the upper leaves irregularly three to five-parted, often entire.

Flower-heads.-Large, yellow, three to four inches across, borne on long peduncles. Rays six to ten, oblong, neutral, more or less drooping. Disk-florets fertile. Receptacle convex, becoming elongated in fruit. Pappus a short crown.

The Cut-Leaved Rudbeckia differs considerably in appearance from the others of the Sunflower group. Its flower-heads begin life broad and flat-facing the sun-but as time goes on and the disk-florets are fertilized, and the akenes begin to mature the receptacle lengthens, becomes cylindrical, and the rays begin to droop; this continuing some little time before the final collapse, which occurs as the last florets open. The leaves are cut and cleft and lobed almost to the point of formlessness, although there seems 


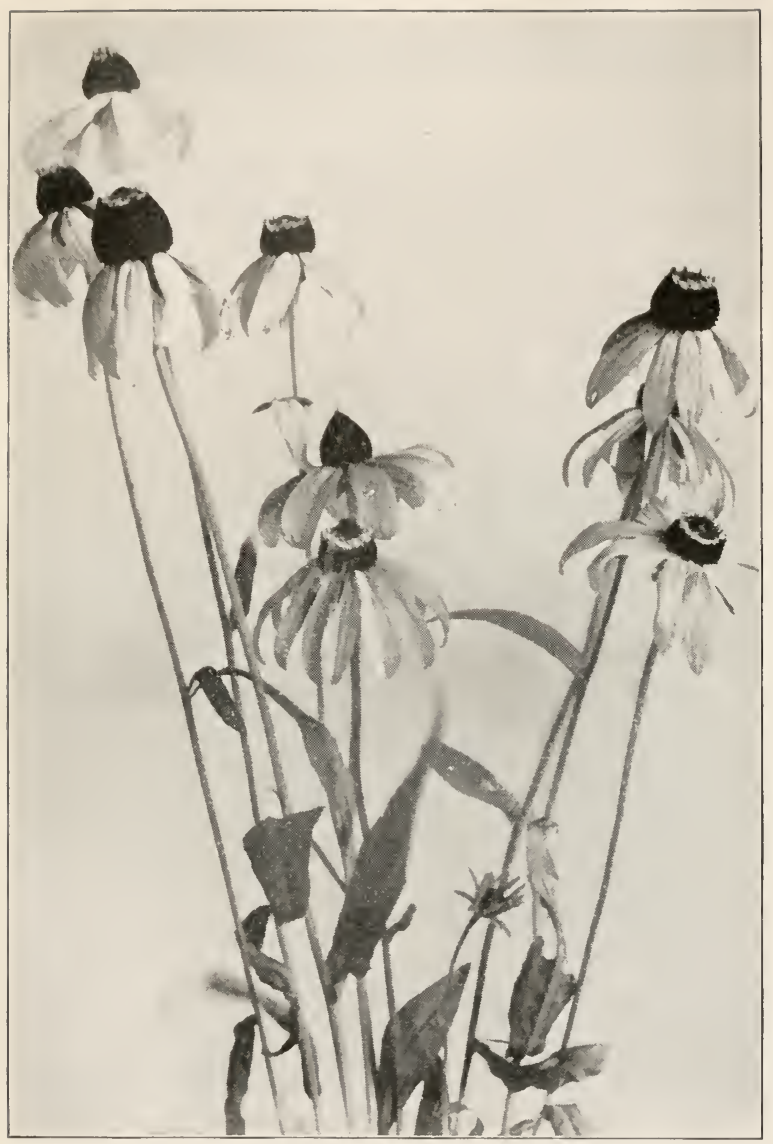

Great Rudbeckia, the Flowers About to Collapse Rudbéckia laciniata 

to be a real effort to keep to a pinnate three to five-cleft type. The plant loves moist places, abides in thickets, and is continental in its distribution. Black-Eyed Susan, Rudbeckia hirta, is the best-known member of the genus and is found in meadows and thickets from June to September.

\section{HELENIUM. SNEEZEWEED \\ Helènium autumnàle}

Helenium, after Helen of Troy.

Native, perennial. An erect branching plant bearing very beautiful flower-heads, yellow, with the disk-florets on a globular receptacle. Alluvial river banks; common in Middle West but rare in New England. September, October.

Stem.-One to three feet high, angular, branching at the top, nearly smooth, often sprinkled with aromatic resinous globules.

Leaves.-Alternate, lanceolate, toothed, more or less decurrent on the stem.

Flower-heads.-Showy, yellow, borne in corymbose clusters at the summit of the stem. Rays spreading, wedge-shaped, eight to ten, three to five-cleft at tip, 


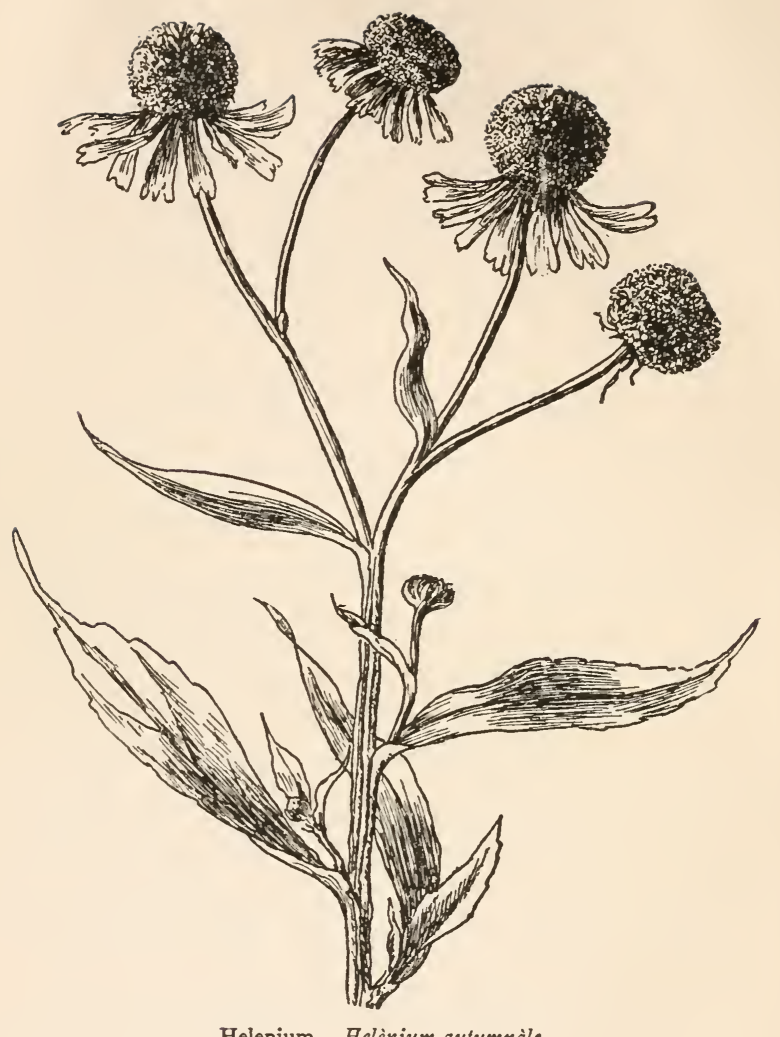

Helenium. Belènium autumnàle 
fertile. Receptacle globose, throwing the disk-florets into a sphere. Involucre small, reflexed; scales, linear; akenes, top-shaped; pappus of five to eight chaffy scales, bristle-pointed.

With the Sunflowers but not of them, marked by a globe of yellow disk-florets and toothed yellow rays, stand the Heleniums, daughters of Helen, erect, stately, and beautiful, worthy of their classical name. One finds them along river banks, of ten just out of the water, almost ready to wade in. A single species of a single genus, they have been warmly welcomed into the garden, where they may now be found, varying in color from pale yellow to orange-brown, yet never losing their stately poise or the rare beauty of the flower. 


\section{THE GOLDENRODS}

\section{Solidàgo}

Solidago, to heal, referring to some alleged curative property of the plant.

"When the wayside tangles blaze

In the low September sun;

When the flowers of summer days

Droop and wither one by one;

Reaching up through bush and brier

Sumptuous brow and heart of fire

Flaunting high its wind-rocked plume,

Brave with wreath of native bloom

Goldenrod."

-Dora Read Goodale.

The Goldenrods are a group of American plants which give much of the characteristic appearance to our northern autumns. All the species make ready in August for the great game, a few like the Early Goldenrod begin earlier than that, but most of the group wait for the hazy golden days of September before they spread their bloom like a cloth of gold over the landscape.

The individual florets of the many species 
vary little, the specific differences are largely in the stem, the leaves, and the habit of growth. The stem may be rough or smooth, hairy, angular or round; the leaf may be three-veined or featherveined; the flowers may have relatively large or small rays, few or many, but every plant is unmistakably a Goldenrod. The flower-heads are small, they sit on the upper side of the stem in order and very close together, all with one exception are yellow. Both ray and disk florets are fertile and produce akenes with pappus. The leaves of all the species are alternate.

Unless one is a trained botanist it is wasted energy to try to distinguish any but the wellmarked species of the genus; moreover, Goldenrod hybridizes to the discomfort of even the elect botanist.

\section{YELLOWTOP. EARLY GOLDENROD}

\section{Solidàgo juncea}

Native, perennial. An Early Goldenrod which in northern Ohio of ten appears the last of June, and continues blooming into September. 


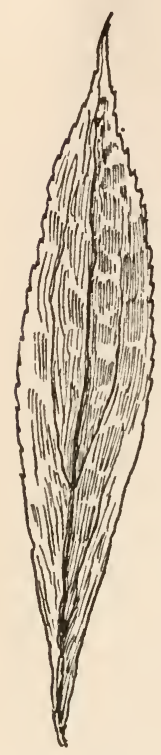

Leaf of Early Goldenrod. Solidàgo júncea. 3 to 5 in. long

Stem.-Rigid, rather stout, simple or branched at the summits, smooth or slightly ridged.

Leaves.-Alternate, lanceolate or oblong, firm, smooth, acute or acuminate, serrate, serrulate, or nearly entire, narrowed at base, often with a tiny leaf wing at either side of the petiole. Midvein prominent beneath; veinlets obscure or wanting. Lower leaves are large, longpetioled; the upper ones smaller and sessile.

Flower-heads.-Bright yellow, borre in a loose, branching panicle. Rays small, seven to twelve, fertile. Diskflorets about fifteen. Bracts of the involucre minute, yellowish, in three or four rows. Pappus yellow-white.

The Early Goldenrod appearing by the roadside in the June tangle is a distinct surprise, for these are the days of Bouncing-Bet and Wild Sweet Clover romping along the railway track, and Goldenrod, beautiful as it is, seems just a little out of due time; a charming guest, but a trifle early for the party. 


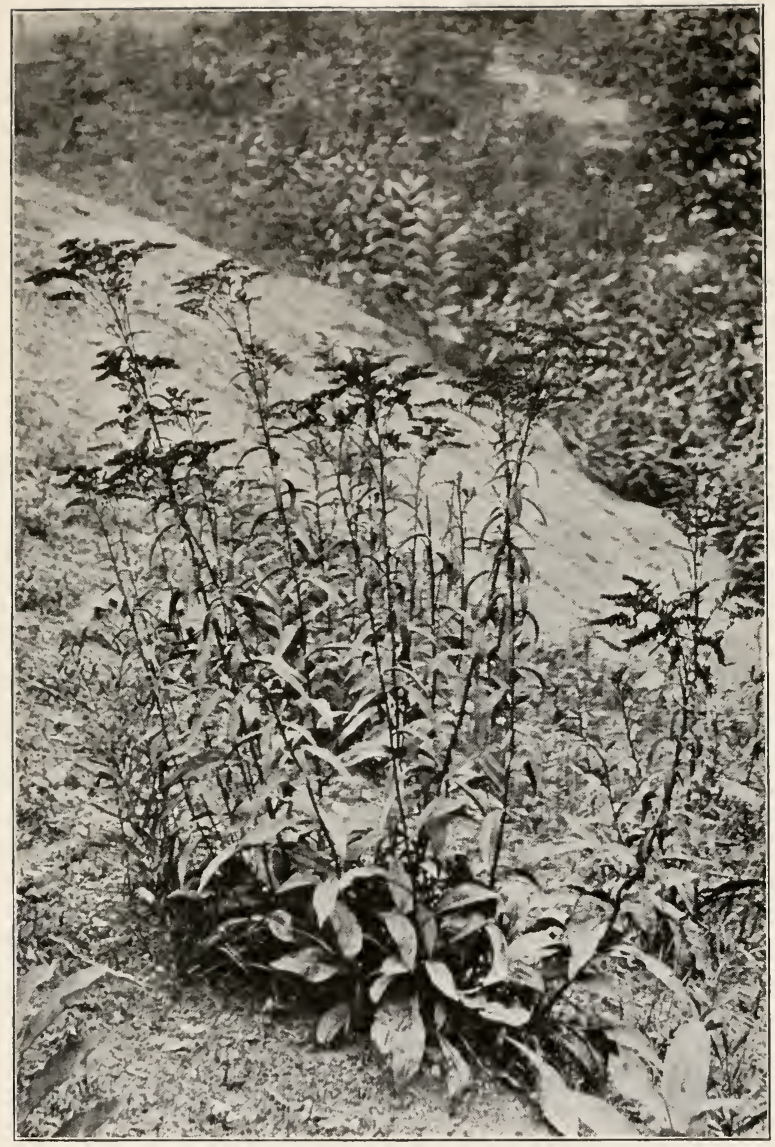

Early Goldenrod at Jome. Solidàgo juncea 



\section{WRINKLE-LEAVED GOLDENROD \\ HAIRY GOLDENROD}

Solidàgo rugòsa

Native, perennial. In fields and along roadsides, common everywhere, mid-season type.

Stem.-Stout, hairy, three to five feet high, simple or branched at the summit.

Leaves.-Alternate, oval or oblonglanceolate, acute or acuminate at the apex, narrowed at the base, sharply serrate from middle to apex, either sessile or the lowest sometimes tapering into petioles; rugose-veiny beneath. Three to five inches long, about an inch wide.

Flower-heads. - Borne in terminal branching panicles, rather small. Rays medium size, six to nine; disk-florets four to seven.

A very rough or hairy Goldenrod, common on wooded roadsides and margins of fields. One of the

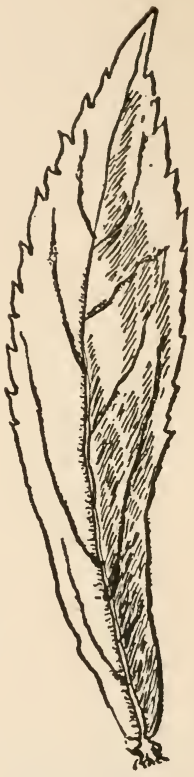

Leaf of WrinkleLeaved Goldenrod. Solidàgo rugòsa. 3 to 5 in. long mid-season group; its plume of flowers is not particularly distinctive, but its wrinkled, manyveined leaf is characteristic. 


\section{COMPOSITE FAMILY}

\section{FIELD GOLDENROD}

Solidàgo nemoràlis

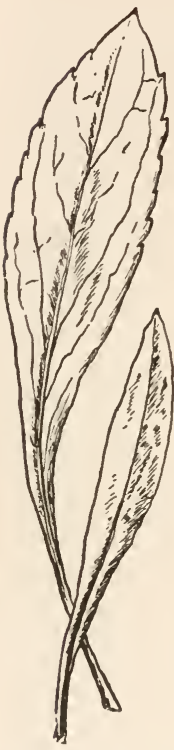

Field Goldenrod, Basal and Stem Leaf. Solidàgo nemoràlis. 3 to 6 in. long

Native, perennial. A low, midseason species, of ten taking undisputed possession of an entire field. Brilliant yellow. Common.

Stem.-Grey-green, slender, one to two feet high, finely pubescent.

Leaves.-Basal and lower stem-leaves petioled, spatulate, obtuse or acute, entire or crenate-dentate. Upper leaves growing smaller as they ascend the stem, entire, acute, often sessile.

Flower-heads. - Borne in more or less spreading, recurved, usually one-sided panicles. Rays minute, five to nine. Pappus fine, white.

Solidago nemoralis is the lowgrowing Goldenrod of dry, open fields, and may be recognized by the peculiarity of its recurved racemes all bending in the same direction over very considerable areas as the whole field turns yellow. The plants are uniformly from one to 


\section{SEASIDE GOLDENROD}

two feet high, and the dense mass of golden plumes, waving in the wind with one accord, makes a veritable field of gold.

These golden plumes of ten give very curious effects. A traveller on a road, with banks a few feet high bordered with bushes, often finds the tiny plumes bowing to him from each side as if in courteous welcome. In an area of extent, as sunlight and shadow succeed one another, there seem to be ripples of yellow flowing over the field; and most interesting of all is a group of a dozen or more stems, no two bowing in the same direction, as if in family feud. There is no end to the pathetic fallacies one may summon concerning these little plants.

\section{SEASIDE GOLDENROD}

Solidàgo sempérvirens

Native, perennial. A very brilliant Goldenrod of salt marshes, sea beaches, borders of tidal rivers, and in sandy soil near the sea. New Brunswick to Florida. August-December.

Stem.-Stout, leafy, usually simple, two to five feet high, smooth, sometimes slightly pubescent. 


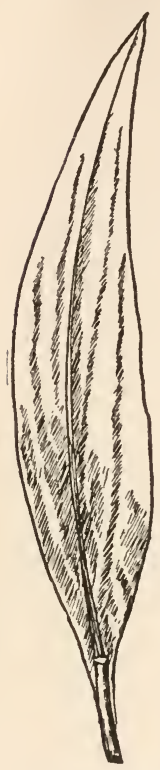

Leaf of Seaside Goldenrod.

Solidàgo sempérvirens.

8 to 12 in. long

Leaves.-Basal and lower leaves with two to five pairs of lateral veins, oblong, spatulate or lanceolate, mostly obtuse, sometimes a foot or more long, narrowed into long petioles; upper leaves sessile, lanceolate to oblong-lanceolate, acute.

Flower-heads.-Thickly set on short, spreading, recurved branchlets, which form a large, showy terminal plume. Rays, large, eight to ten; bracts of involucre lanceolate, acute.

"Graceful tossing plumes of glowing gold, Waving lonely on the rocky ledge."

Solidago sempervirens grows of choice within sound of the sea, delighting in thick fogs and salt spray, the moisture and the coolness of the shore. It is found in the tangle just above high tide with Asters and Jewelweed and Tansy, or looking seaward from the edge of a cliff. Its earliest heads unfold about the Ist of September; by the $15^{\text {th }}$ it gives a yellow glow to the seashore tangle. The plant is vigorous, succulent, soft to the touch, smooth, and sometimes 
shining. The basal leaves are oblong and taper into long stems. The individual flowers are rather large; in the bud they are more distinct and separate than those of other species.

\section{SILVER-ROD. WHITE GOLDENROD}

Solidàgo bicolor

Native, perennial. The only Goldenrod with white rays; belongs to the late-flowering group. Common. Maine to Georgia and westward.

Stem.-Usually simple, rarely branched, erect, soft grey-green, hairy or smooth, one to two feet high.

Leaves.-Basal and lower leaves obovate or broadly oblong, mostly obtuse, two to four inches long, narrowed into long margined petioles, dentate or crenate-dentate, more or less pubescent; upper leaves smaller and narrower, oblong or lanceolate, often entire.

Flower-heads.-Borne in small flower clusters at the leaf axils, or crowded into a cylindrical terminal spike. Rays three to twelve, white. Disk-florets cream yellow.

Silver-Rod is the only Goldenrod with white rays. Sometimes the plant gets a plumy top, 


\section{COMPOSITE FAMILY}

but usually it is a simple wand bearing yellowish white flowers along the upper half of the stem.

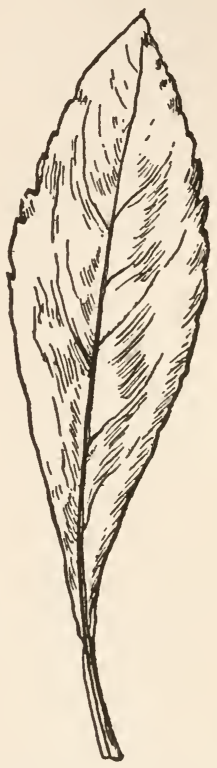

Leaf of Silver-Rod. Solidàgo bicolor. 2 to 4 in. long

Rather a late mid-season bloomer, it is to be looked for in company with the Blue Wood Aster and the Blue-Stemmed Goldenrod. 
BLUE-STEMMED OR WREATH GOLDENROD Solidàgo cèsia

Native, perennial. A late-blooming species, characterized by its many clusters of flower-heads borne along the stem in the axils of the leaves. Roadsides and by thickets. Common.

Stem.-Slender, bluish or purple, smooth, often with a plum-like bloom on the curving stem, one to three feet high, rarely branching.

Leaves.-Sessile, lanceolate to oblong, acuminate at the apex, narrowed at the base, sharply serrate, two to five inches long; one-half to one inch wide; they grow smaller as they ascend the stem.

Flower-heads.-Borne in clusters or short racemes in the axils of the leaves; the top of the stem at the same time often bearing a short terminal thyrsus. Rays three to five, rather large.

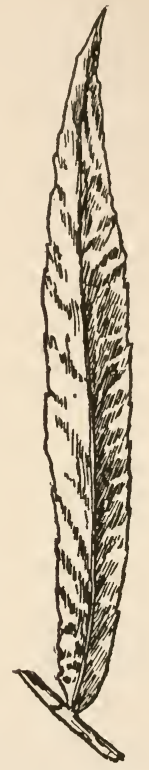

Leaf of Wreath Goldenrod. Solidìgo césia. 2 to 5 in. long

The Blue-Stemmed Goldenrod is the species credited with giving the name Goldenrod to the genus. A well-grown specimen is in fact a 


\section{COMPOSITE FAMILY}

golden rod or wand, without question or cavil. The slender stem rises two feet or more, bearing a wealth of leaves arranged alternately, and in the axils of these are clusters, perhaps an inch across, of golden yellow flower-heads. These begin rather low on the stem, and continue to the top, where there is often a tiny thyrsus, that is, a flower cluster like that of the lilac. This is, indeed, a golden sceptre worthy of any woodland queen. The Wreath Goldenrod is to be looked for in company with the White Wreath Aster, as both are late-flowering plants.

\section{BROAD-LEAVED GOLDENROD}

Solidàgo latifòlia. Solidàgo flexicàulis

Native, perennial. A late bloomer, appearing on rich, moist, wooded banks, and borders of thickets. Maine to Georgia and westward.

Stem.-One to three feet high, green, zigzag, angled in section and rarely branched.

Leaves.-Broadly ovate or oval, sharply serrate, conspicuously pointed at both ends, three to six inches long. 
Flower-heads.-Borne in short axillary clusters, or somewhat prolonged at the ends of the branches. Rays large, three to four.

In northern Ohio the Broad-Leaved Goldenrod is the last and latest species of the genus, the latest to bloom and the last to remain. As a rule it outlasts $S$. Canadénsis, it may be no more hardy, but being low and growing in more protected places, it withstands frosts and snows more successfully. It appears fresh and green when its companions are in the doldrums.

\section{LANCE-LEAVED GOLDENROD. FLAT- TOPPED GOLDENROD}

Solidd̀go lanceolàta. Euthàmia graminifòlia

Native, perennial. A species distinctly different from all the foregoing in that its flowerheads are borne in a flat-topped cluster. On river banks, open fields, moist situations everywhere.

Stem.-Smooth, sometimes slightly rough, two to four feet high, branched.

Leaves.-Linear-lanceolate, acute or acuminate, entire, minutely rough on the margins, sessile. 


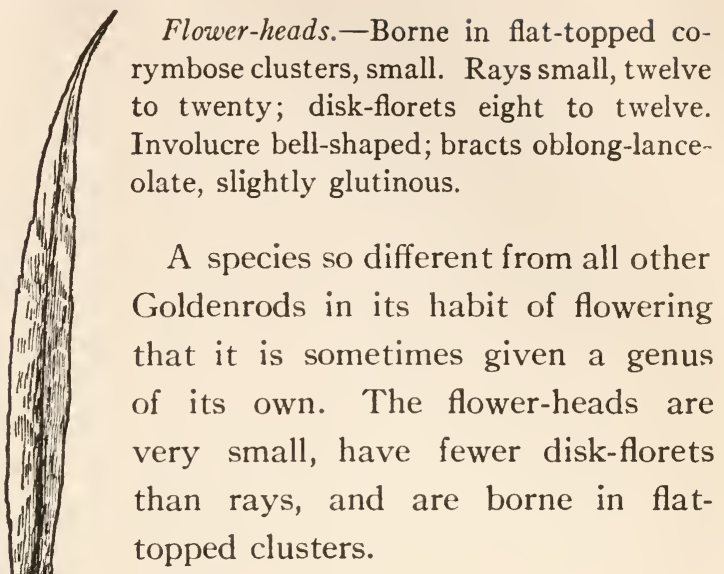

\section{MID-SEASON GOLDENROD}

Solidàgo serótina

A common mid-season Goldenrod,

Leaf of Flat-

Topped

Goldenrod.

Solidàgo

lanceolata.

2 to 5 in. long

found on roadsides and borders of thickets. Of continental distribution. August-October.

Stem.-Stout, straight, three to six feet high.

Leaves.-Three-ribbed, lanceolate, narrow, pointed at base and apex, serrate with small teeth, rough above, three to four inches long. 
Flower-heads.-Panicle usually plume-like rather than bushy. Rays ten to fifteen, narrow.

Solidago serotina is named in the books the Late Goldenrod, but instead it is quite a midseason species, found frequently in company with S. Canadensis, but usually in full bloom as Canadensis is getting ready or just beginning to bloom. The leaf is definitely three-ribbed, the flowering panicle a plume rather than a bushy head. The rays are narrow, but as there are a good many of them, the golden glory of the plume is assured. The earlier botanies were inclined to regard this as a form of Canadensisthe two forms undoubtedly run together.

\section{CANADA GOLDENROD}

Solidàgo canadénsis

Native, perennial. A tall, stout, coarse, lateflowering species, with triple-ribbed leaves and bushy panicles. Very abundant, variable. New Brunswick to Northwest Territory, south to Florida and Arizona. 
Stem.-Stout, tall, three to ten feet high, rough-hairy.

Leaves.-Oblong or lanceolate, three-veined, sharply serrate, rarely entire, acute at apex and at base, more

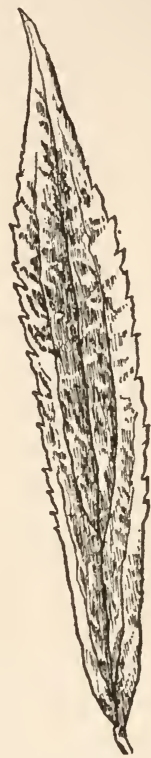

Leaf of Canada Goldenrod. Soliddago Canadénsis. 3 to $8 \mathrm{in.} \mathrm{long}$

or less pubescent beneath, and rough above. Lower leaves serrate and petioled, three to six inches long; upper leaves smaller, mostly entire and sessile.

Flower-heads.-Borne in a large, loose panicle. Heads small, rays short, nine to fifteen. 
The little Goldenrods: Bicolor, Wreath, and Broad-Leaved, are all present, snuggling in among the Asters and protected by the wrack and welter of summer glory and summer weeds, when this gay and gallant creature, the Canada Goldenrod, appears in force. The earlier Goldenrods have passed from glory to glory, mixing their yellow plumes with the flowers of summer, and their feathery gold has much of it faded to the soft pale ghost of its former loveliness. But now this glorious Goldenrod, coming out from the wheat-fields of northern Canada, flinging its magnificent beauty over a continent, marching southward to the Gulf, is one insistent, pervasive, ever-present fact of autumn that even the blindest and dullest cannot fail to note.

The plant is equipped for its long journey: it is tall and strong, its stem stout and woody; its three-ribbed leaves well clothe its stem, and it overtops most of its companions. 


\title{
THE ASTERS
}

\author{
Aster, a star.
}

The amateur may divide our common roadside Asters into three groups, and so easily become acquainted with a number sufficiently large to give a good beginning. Should one go farther, he studies books and herbariums, and goes far afield.

In the first group may be placed those of largest size; the one best known because it has been largely introduced into gardens and landscape planting, is the New England Aster, $A$. Novve Anglice, a beautiful species, its size about that of a silver half-dollar, sometimes larger, and in color varying from violet-purple to deep rose, pink, and sometimes white. A second species almost as abundant, and readily recognized, is the RedStemmed Aster, A. puniceus, a lover of moist places, a dweller in ditches by the roadway. The third is the Seaside Aster, A. spectábilis, its flower-head also the size of a half-dollar, pale lavender 
in color, a plant dwelling of choice by the sea, and rarely wandering far from the sound of its waves.

The White Aster group includes one of the earliest species, the White Wood Aster, $A$. divaricàtus, rather dishevelled in appearance, and standing at the edge of woods. The Tall White, A. paniculàtus, is abundant along upland roadsides, its bushy top bearing many heads which in size vary about that of a tencent piece. Tradescant's Aster, Farewell Summer, and the White Heath Aster are the two most abundant White Asters of the roadsides. The Whorled Aster, A. acuminatus, is the White Aster of high latitudes and mountain tops, abundant in the White Mountain region, and $A$. multiflorus is the late densely flowered species.

A third group of small and medium-sized Asters, pale blue or violet, includes $A$. cordifòlius, A. macrophỳllus, A. prenanthoides, A. pàtens, A. lèvis, and A. undulàtus. There are, of course, many others, but these are very generally distributed and not difficult to determine. 


\section{COMPOSITE FAMILY}

The brilliancy of Aster roadside color is contributed largely by the New England species; it is first, and there is no second. The white drift of the roadside in mid-October is made by the combined flowering of Farewell Summer and White Heath Aster; the purple mist in swamps and low wet lands is largely $A$. puniceus, the Punic Aster.

The bluish clouds that abide in the open woods are mostly $A$. cordifolius, prenanthoides and undulatus, all comrades, all fearless, all beautiful. In the section of northern Ohio that I know, neither $A$. patens nor $A$. lavis is abundant. A. multiflorus is always a wonder that one stem can accommodate so many flower-heads.

All Asters are Radiate-Composites, the rays sit like the points of a star around the central disk. Upon this disk, in a well-opened head, we can distinguish the young seed (akene), the pappus, the tubular five-lobed corolla, the anther tube and the stigmas. The ray-florets are pistillate, and produce seeds. Bloom begins at the top of the branchlets; all secrete abundant nectar. 


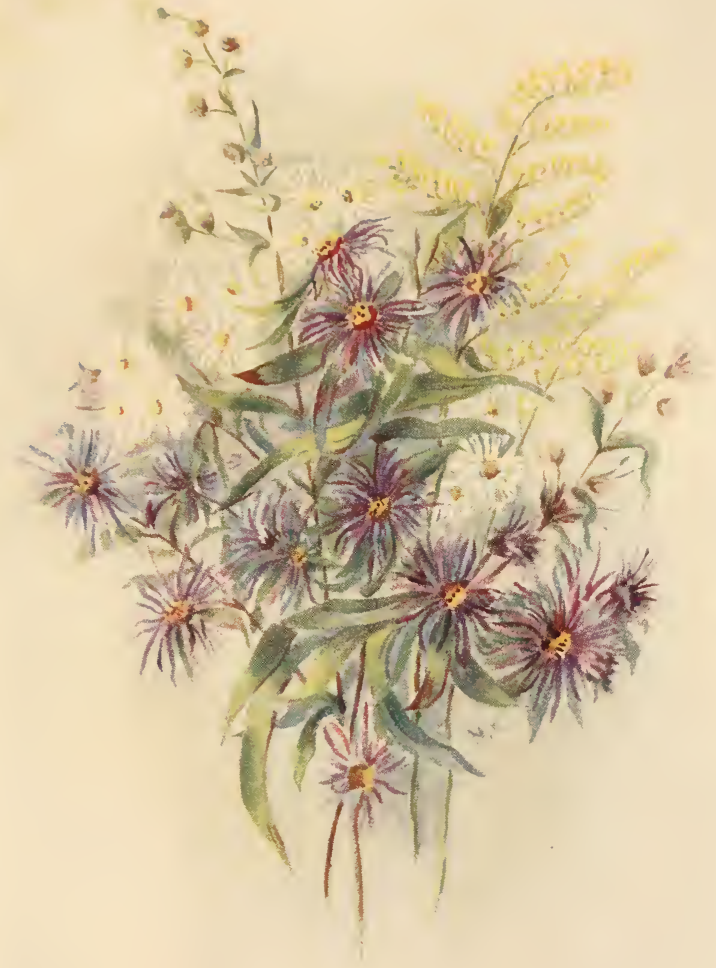

Asters in variety 

The Asters have two well-defined groups of leaves, basal and stem, usually quite different. The disk-florets after flowering often change from yellow to red, brown, or purple. All have pappus, white or tawny, which is the Asterremnant of the compressed calyx.

\section{NEW ENGLAND ASTER}

\section{Aster Nòvce-Ánglice}

Native, perennial. A very showy, abundant and beautiful Aster. In fields and roadsides, from Canada to South Carolina, west to Kansas and Colorado. August-October.

Stem.-Two to five feet high, stout, rough, pubescent, leafy when young, corymbosely branched at the summit.

Leaves.-Stem-leaves two to five inches long, oblonglanceolate, pubescent, entire, acute, clasping the stem by an eared or heart-shaped base. In early autumn the stem-leaves often turn brown and fall.

Flower-heads.-Violet-purple, red-purple, rose, white. Many, in size about that of a silver half-dollar, sometimes larger, densely clustered at the ends of the branches, which appear on the upper half of the stem. Rays forty to sixty, linear. Involucre bell-shaped; bracts in several rows, linear, pointed, green often suffused with purple, spreading. Pappus tawny. 


\section{COMPOSITE FAMILY}

The flowers of New England Aster are normally a deep violet-purple, or a rich red-purple,

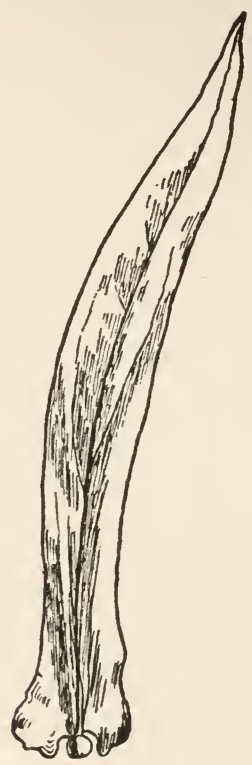

Leaf of New England Aster. Aster Nòre Anglia. 2 to 5 in. long

but one often finds a group of lovely rose-pinks, rarely a red, sometimes even white, and by no means infrequently there appears a cluster bearing heads varying from white to rose-purple. 


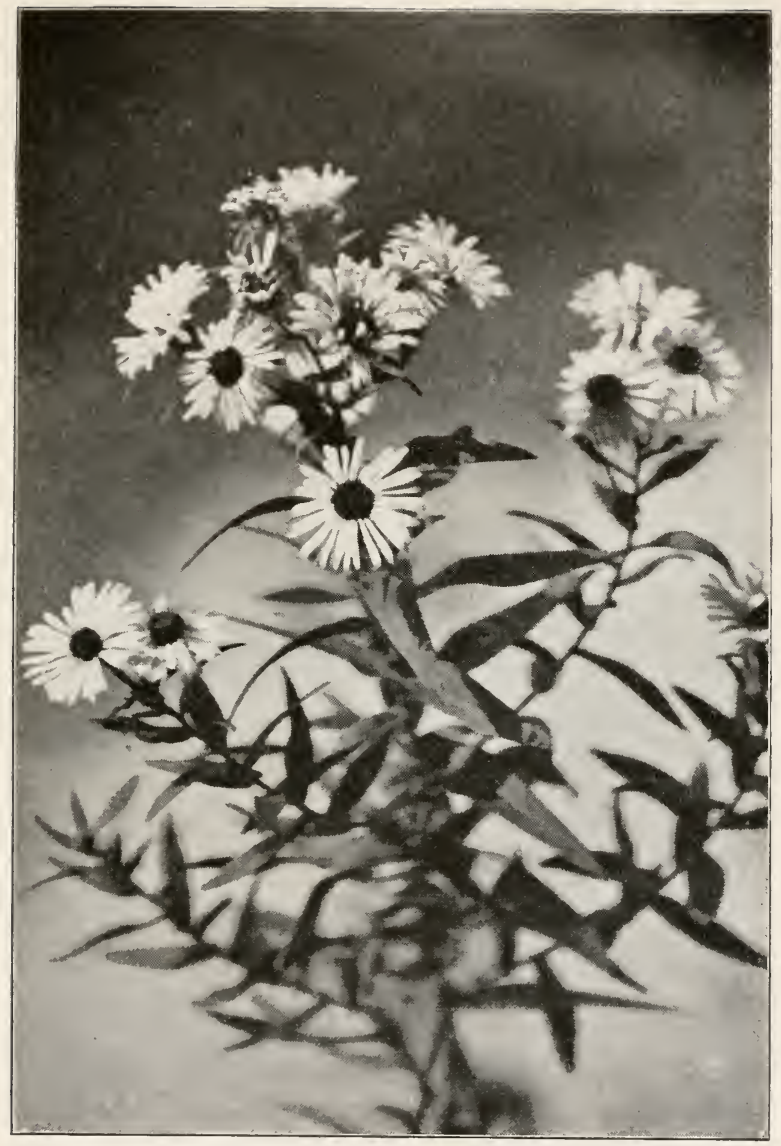

New England Aster. Aster Vö̀ce Ánglice 



\section{RED-STEMMED ASTER}

This Aster is very generally cultivated by landscape-gardeners, and is worthy of all the attention it has received. It adorns and glorifies the roadsides from New England to Colorado.

The defect of this Aster is that just when the bushy top is in full bloom the stem gets "leggy," that is, the leaves turn brown and drop, and so leave youth and beauty swinging to the breeze from the summit of a bare brown shining stem. Consequently the plant is most satisfactorily placed when planted with shrubbery, as this supplies the desired foliage. When the full flowering period sets in, the collapse of the leaves often follows.

\section{RED-STEMMED ASTER. PURPLE- STEMMED ASTER}

\section{Aster puniceus}

Native, perennial. A purple-stemmed, rather tall Aster, commonly found in low, moist, and swampy places as well as roadside ditches. Nova Scotia to Minnesota and south to North Carolina. August-November. 


\section{COMPOSITE FAMILY}

Stem.-Three to six feet high, branching widely from the bottom of the stem. Stout, rigid, bristling with hairs and generally red or purple.

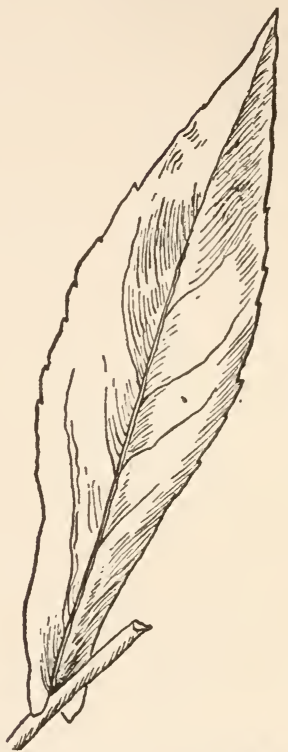

Leaf of Red-Stemmed Aster. Aster punicews. 3 to 6 in. long

Leaves.-Long and narrow, ovate or lanceolate, narrowing somewhat toward the base, serrate, varying from coarse teeth to few or none; apex acute or acuminate, clasping the stem with heart-shaped base; upper surface rough, under side of midrib hairy. 
Flower-heads.-Many, showy, lilac-blue, rarely white; varying in size about that of a silver half-dollar. Ray-florets thirty to fifty, long, narrow. Involucre bell-shaped; bracts in two rows, linear, smooth, green, spreading. Pappus white.

This Aster loiters by the ditches, lives in swamps and looks out contentedly from any moist location. Its bloom begins sparingly, showing a few flower-heads here and there in August, but the full burst of its rare beauty is later. The individual plant is very attractive because the branches appear low down on the stem, in time forming a leafy mass bearing flowers from top to bottom. Sometimes it is mistaken for New England Aster, but the points of difference are several. The color of Red-Stemmed flower-heads is always a pale violet-blue, while the New England blossoms run a chord of purple to rose. The poise of the plants differs considerably.

A. puniceus sends out long branches all the way up the central stem, and these bear flowers on tiny branchlets, while New England normally 
is a single leafy stalk that bears its flowers in a bushy head at the top.

Puniceus means Punic, Carthaginian, royal purple, just what it is not, provided anybody knows what royal purple is, or was in ancient times. The plant blooms very deliberately in middle August, one bright, wide-open glad star here and there, but when September comes it is a dance of the fairies waving in the wind.

\section{SEASIDE ASTER. SHOWY ASTER} Aster spectábilis

Native, perennial. A plant of the seashore growing in dry, sandy soil. Massachusetts to Delaware, mostly near the coast.

Stem.-Stiff, simple or corymbosely branched, slightly hairy or rough, one to two feet high.

Leaves.-Basal and lower leaves oval, acute, three to five inches long, sparingly dentate with low teeth, narrowed at base into slender petioles; upper leaves sessile, entire, acute, linear-oblong.

Flower-heads.-Several or many, showy, violet; in size about one and one-half inches across; rays fifteen to thirty. Involucre hemispherical; bracts linear ob- 
long, imbricated in about five series and the greenish tips spreading. Pappus white.

The Seaside Aster, like the Seaside Goldenrod, is a rare and beautiful species of its kind. Found only near the coast, of ten where the foliage is wet with the salt spray of the sea, it forms a bushy mass of pointed leaves which is covered more or less abundantly with beautiful violetblue flower-heads, in size about that of a silver half-dollar. It is well named spectabilis, for it is one of the loveliest of the clan.

\section{WHITE WOOD ASTER}

Aster divaricàtus

Native, perennial. An early White Aster found in open woodlands in rather dry soil. Canada, southward to Georgia and Tennessee.

Stem.-More or less zigzag, one to two feet high. branching at the top and repeatedly forked.

Leaves.-Thin with slender petioles, broadly ovate, serrate-dentate with sharp teeth, cordate at base, acute at apex.

Flower-heads.-White in loose flattish clusters. Rays white, six to nine; disk yellow, soon turning brown. 
Involucre with broad bracts, the rounded tip having an inconspicuous green spot.

The White Wood Aster comes into bloom in certain elect places the middle of August. It retreats a few feet from the edge of the woodland but seldom beyond the zone of abundant sunlight, and sometimes it breaks out in dry, sunny places.

The lower leaves are heart-shaped, sharply toothed, long-pointed with a grooved petiole. The flower-heads are ragged, the few rays pointing hither and yon, and the entire effect dishevelled and unkempt.

\section{TALL WHITE ASTER. PANICLED ASTER} Aster paniculàtus

Native, perennial. One of the tall, showy White Asters, following upland roads in midsummer, reported as preferring moist locations but really growing anywhere when provided with a cool root-run. New Brunswick to western Ontario, south to New Jersey, Kentucky, and Kansas. 


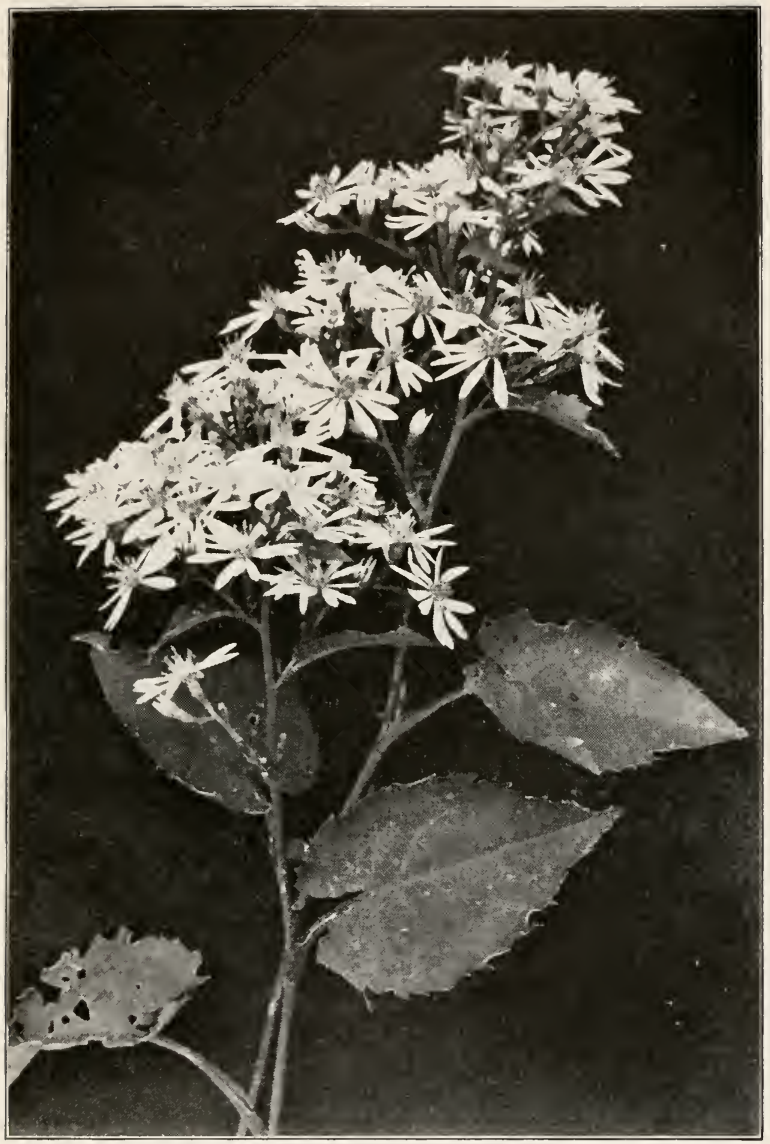

White Wood Aster. Aster divaricatus 

Stem.-Smooth, two to seven feet high, much branched at the top making either a flattish or a pyramidal head.

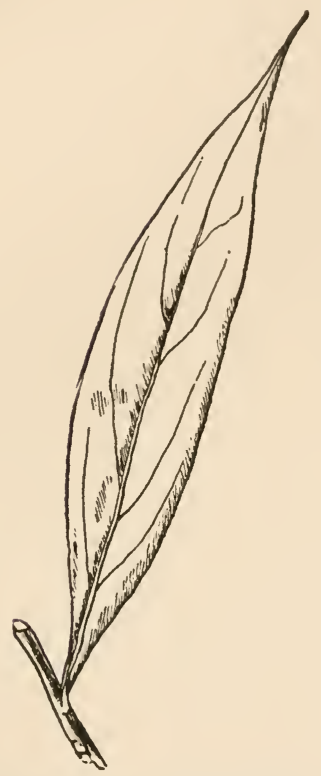

Leaf of Tall White Aster. Aster paniculatus. 3 to 6 in. long

Leaves.-Stem-leaves lanceolate to oblong-lanceolate, acuminate at apex, narrowed to a sessile or slightly clasping base, smooth, usually thin, sparingly serrate in the middle or very nearly entire; three to five inches 


\section{COMPOSITE FAMILY}

long, three-fourths to an inch wide, growing smaller as they ascend the stem.

Flower-heads. - White, many, on leafy branches. Heads one-half to three-fourths of an inch across. Rays ten to fourteen, white. Disk-florets pale yellow fading to brown. Involucre hemispherical; bracts linear-lanceolate, acute, green-tipped, in four or five rows. Pappus nearly white.

The Tall White Aster not unfittingly in September takes the place on upland roadsides which was so charmingly filled by the Tall Meadow-Rue in July. The stem rises to five feet and at the summit bears flattish clusters of white stars. In time these clusters lose their flat contour and become rounded or pointed, but the branching habit of the plant is paniculate, which means that the inflorescence is massed at the top of the stem.

WHITE ASTER. FAREWELL SUMMER. TRADESCANT'S ASTER

Aster Tradescánti

Native, perennial. An abundant White Aster of autumn, blooming profusely along waysides 62 
both wet and dry. New England, Ontario to Northwest Territory, south to Illinois, Ohio, Pennsylvania and West Virginia. AugustNovember.

Stem.-Slender, paniculately branched, two to five feet high; branches usually ascending and often pubescent in lines.

Leaves. - Stem-leaves lanceolate or linear-lanceolate, very pointed, acuminate, narrowed to a sessile base, commonly thin, serrate with low teeth in the middle, or entire.

Flower-heads.-Numerous, in large raceme-like panicles. Five to seveneighths of an inch across. Rays white, thirty-five to forty. Involucre bellshaped; bracts minute, green-tipped, in several rows. Pappus white.

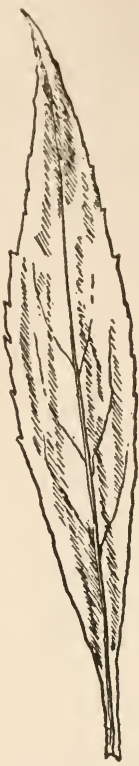

Leaf of Farewell Summer.

Aster Tradescanti. 2 to 5 in. long

The books give to this Aster the name of Michaelmas Daisy as well as Farewell Summer. Michaelmas Daisy has been appropriated so many times before that it is now meaningless, but Farewell Summer is not only 
an individual and appropriate name, but it is a species of folk-lore name of which we have too few examples, willingly to lose any that seem to the manner born. Tradescant, of course, commemorates a botanist of fame, and is not unworthily placed.

This is the common White Aster of autumn days; one finds it everywhere; with the whole countryside to play in it still crowds along the roadways, runs through the vineyard aisles, is found in every tangle, wet or dry. The plant makes ready for bloom in late August, and in early September launches a few tiny flowerheads here and there, but by October apparently it is everywhere-a veritable flowering of the ditches, a descent of the stars. By this time the upper half of the plant is a mass of white Aster-heads, varying in size from a tencent piece to a silver quarter.

The stems are leafy with leaves both small and great, which bear considerable cold before they fall. It is interesting that the flowers of Asters last longer and withstand more vicissi- 
tudes than the leaves. White Heath Aster of ten companions the White Aster, the two side by side comfort the desolation of early frosts along highway and byway, and though they bravely look winter in the face, a farewell to summer is borne on each of their trembling petals.

\section{WHITE HEATH ASTER}

Aster ericoides

Native, perennial. A profusely blooming White Aster of bushy type and found along roadsides and in dry fields, marked by many bract-like leaflets. Maine and Ontario, south to Florida, west to Wisconsin. SeptemberNovember.

Stem.-One to three feet high, smooth, hard, woody, branching and bushy.

Leaves.--Basal leaves spatulate, obtuse, slightly dentate or entire, sometimes with margined petioles. Stem-leaves narrowly linear, three to four inches long, growing smaller as they ascend the stem, acute, entire. Leaves of branchlets awl-shaped, many.

Flower-heads.-Numerous, white, three to fiveeighths of an inch across. Rays twenty to twenty- 


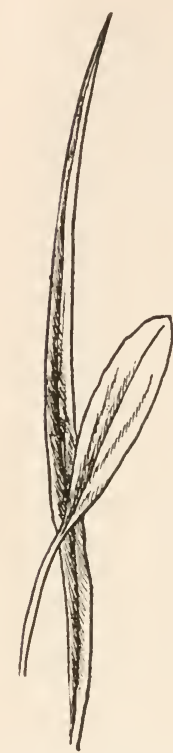

Basal and Stem Leaf of White Heath Aster. Aster ericoides

five. Involucre bell-shaped; bracts small, green-tipped, about three rows. Pappus white.

White Heath Aster is at its best in mid-October. Then it stands in serried ranks along the roadway, often covered with the dust of passing wheels, a little bush twinkling with tiny stars, the largest the size of a nickel, but the run of the flock much smaller. Each flowerhead has twenty to twenty-five white rays and a plump compact yellow centre.

The stem-leaves are a distinguishing character. Beginning as linear about three inches long, pointed at apex and at base, they grow smaller as they ascend the stem, finally becoming simple green lines an inch or less in length. They are, however, abundant enough to clothe both branches and branchlets. As the season advances the bushy top swings upon one bare 
brown woody stem, bows to the wind, shivers in October snows, but so hardy is it that a few flower-heads are often found in the Thanksgiving bouquet. In northern Ohio the White Heath and Farewell Summer stand hand in hand upon the roadway, very similar in appearance, enjoying the present and careless of the future - hardy, fearless and beautiful.

\section{WHITE MOUNTAIN ASTER. WHORLED ASTER}

Aster acuminàtus

Native, perennial. A woodland species with rather large, white, dishevelled flower-heads. Cool rich woods. Labrador to Maine, New York and southward along the mountains to Georgia; abundant in the White Mountain region. August, September.

Stem.-One to three feet high, more or less hairy, zigzag.

Leaves.-Oval or oblong, pointed at both ends, acute or acuminate, serrate beyond the middle, crowded at the summit of the stem. 


\section{COMPOSITE FAMILY}

Flower-heads.-Not very numerous, white or pale lilac. Rays eight to fourteen, narrow; disk-florets

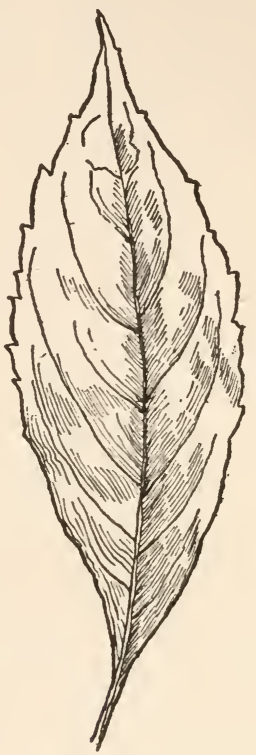

Leaf of Mountain Aster. Aster acuminàtus. 2 to 3 in. long

generally reddish. Appearance of head scrawny, irregular. Involucre hemispherical; bracts linear-acuminate; the outer much shorter. Pappus soft, fine, white. 
The Mountain Aster has little to offer by way of beauty, but the plant is interesting in that it is native to northern latitudes and high mountain tops. Just before flowering the upper leaves of the stem become somewhat crowded, which gives the appearance of a whorl of leaves at the summit. The rays someway fail of orderly development, and, projecting at many angles from the disk, present a dishevelled appearance; they are about half an inch long; did they stay in order they would make a fairly large blossom for an Aster.

\section{DENSE-FLOWERED ASTER. WHITE WREATH ASTER}

Aster multiflorus

Native, perennial. On roadsides, in open woods and fence corners, preferring dry locations to moist. Of continental distribution east of the Rocky Mountains.

Stem.-One to four feet high, much branched; branches long and slender, ascending or spreading, one to two feet long. 


\section{COMPOSITE FAMILY}

Leaves.-Upper stem-leaves of the flowering branchlets rigid, linear or linear-oblong, entire, acute at apex, sessile. Lower stem-leaves two to three inches long,

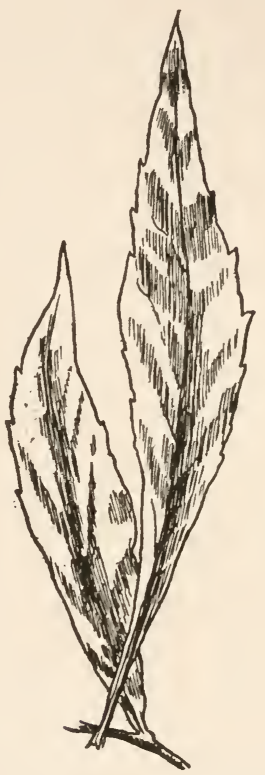

Leaves of White Wreath Aster. Aster multiflorus. 2 to 4 in. long

lanceolate or oblanceolate, slightly serrate beyond the middle or entire, acute or acuminate, slightly clasping at base. Three inches long or more. 
Flower-heads.-Small, white, very crowded on the stem. Centres at first pale yellow but soon become reddish purple. Heads half an inch across or smaller, densely crowded, nearly sessile. Rays ten to twenty, white, inclined to curve backward. Involucre bellshaped; bracts coriaceous, green-tipped, inclined to spread; pappus brownish white.

This Wreath Aster is very well named, for it branches with long, simple stems, often curving out of the tangle, bearing one to three feet of Asters, just Asters, for so small and so crowded are these tiny stars that neither stem that holds them nor leafy bracts that support them are much in evidence. There are just so many feet or inches of crowded florets. The little things are about half an inch across, usually white, sometimes flushed with lilac, but with dark purplish centres, and crowded, always crowded. The rays have a tendency to turn back, which makes the flower seem even smaller than it is, and throws the purplish centres into prominence. The long simple stems curve and reach over their lower companions, and so get light and space. The plant dwells of choice in half shade, 
and is found in company with the Blue Wood Aster, standing in groups or singly at the border of the open wood.

\section{BLUE WOOD ASTER. PURPLE MIST Aster cordifolius}

Native, perennial. One of our most beautiful and abundant Purple Asters standing in open woods and shaded roadsides. New Brunswick to Minnesota, south to Georgia and Missouri. September-December.

Stem.-Two to five feet high, slender, leafy, nearly smooth, often stained with purple.

Leaves.-Stem-leaves rather narrow, heart-shaped, with long petioles, that are more or less margined, sharply serrate, acute or acuminate. The upper leaves ovate or lanceolate, serrate, and acute, the topmost entire.

Flower-heads.-Violet-blue, varying in size from a ten-cent piece to a nickel, clustered on tiny branchlets, making a full paniculate top. Rays fifteen to twenty, violet-blue, deep or pale. Disk-florets yellow, reddish purple with age. Involucre bell-shaped; bracts appressed and tipped with obtuse green points. Pappus white. 
This is a very handsome, small-flowered Aster, so abundant that masses of pale violet-blue mist

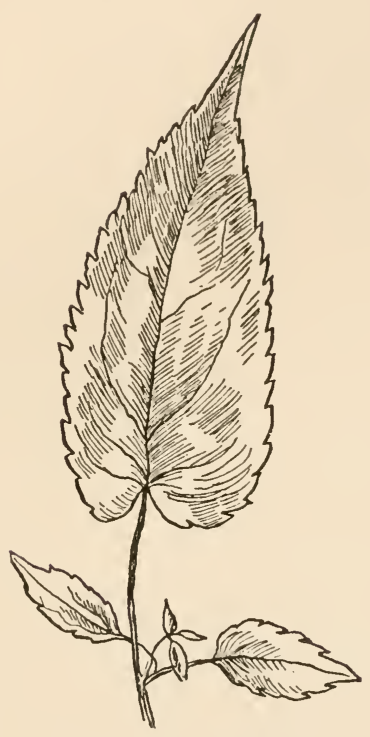

Leaf of Blue Wood Aster. Aster cordifolius. 2 to 3 in. lon 5

seem resting from one to five fect above the green of the earth in and about the open woods and shady roadsides where it abides. Its flower- 
ing season is long, and its starry blossoms light up the leafy ways until the late frosts or early snows finally sweep them away.

\section{PURPLE DRIFT \\ Aster prenanthoides}

Native, perennial. In moist soil of open woods and roadsides; violet-blue.

Stem.-Slightly zigzag from leaf to leaf, hairy though sometimes smooth, much branched, one to three feet high, often stained with red.

Leaves.-Thin, narrow, oblong to broad ovate-lanceolate, abruptly narrowed below into a broad margined entire petiole of an inch long, with a clasping base, more or less eared; serrate sometimes almost entire, acute or acuminate, variable.

Flower-heads.-Abundant, pale violet-blue. Rays fifteen to twenty, about half an inch long. Disk-florets pale yellow darkening to reddish purple. Involucre bell-shaped; bracts green-tipped in three or four rows.

Purple Drift of the roadside in early October, together with Farewell Summer and White Heath Aster make a combination, pale violet with abundant white, most rare and beautiful. When 


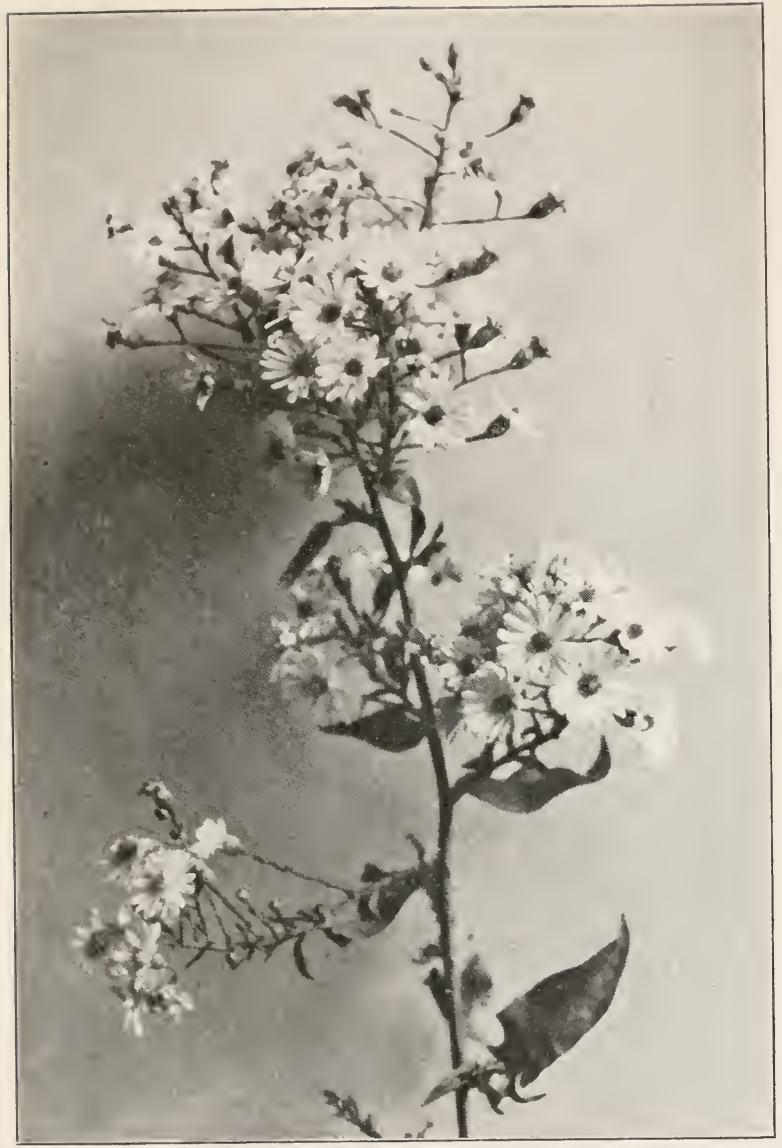

Purple Drift. Aster prenanthoides 

New England Aster, with its dark purple or glowing red, adds a deeper tone to the group

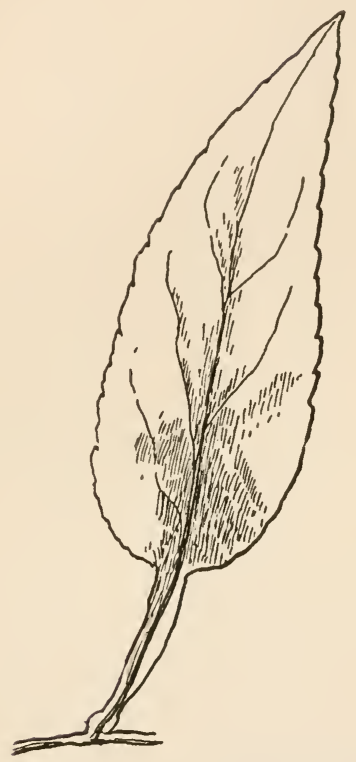

Leaf of Purple Drift. Aster prenanthoides

one wonders were ever roadsides more lovely than in October. There are other pale violet Asters, and they may be in the combination, 
but Aster prenanthoides is easily distinguishable by its abundant bloom, a glowing mass of pale violet brightened by its yellow disks and darkened by its purple ones.

The shape of the leaves is a distinguishing character, oblong or ovate-lanceolate, more or less serrate, with winged petiole-which of ten broaden at the base and clasp the stem. Both leaves and petioles vary, but this is the typical form. The bloom lasts late into autumn.

\section{WAVY-LEAVED ASTER. VARIOUS- LEAVED ASTER}

Aster undulàtus

An Aster of varied leafage, common enough, but not readily recognized. In dry soil, usually in open woods. New Brunswick and Ontario south to Florida, Alabama, and Arkansas. September, October.

Stem.-Stiff, rough, one to three feet high.

Leaves.-Variable, ovate, ovate-lanceolate, cordate, oblong. Petioles naked, margined, dilated at the base. Margins entire, wavy, dentate or serrate. 
Flowe-heads. - In a loose terminal cluster. Rays eight to fifteen, pale lavender to pale blue, half an inch long.

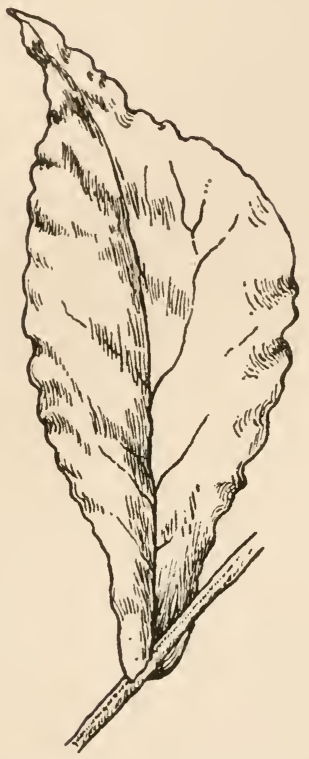

Typical Leaf of Wavy-Leaved Aster. Aster unduldtus

The typical Aster undulatus which named the species is rather a rare form. If one is fortunate enough to find it, one finds an erect stem bear- 
ing leaves whose borders are not merely wavy but actually ruffled. These in shape are ovate or lanceolate, though of ten the leaf seems to be narrowing toward a winged petiole, which makes an obovate form.

But this typical form is not frequent enough to be an infallible guide, especially as a heartshaped leaf on a margined petiole, a leaf contracted to a short, broadly winged petiole, dilated at the base, is not only common, but perhaps the most frequent form. Margins vary -entire, wavy, serrate, dentate-and the apex is either acute or acuminate.

The leaves being so casual one turns to the flowers for help. The stem is crowned with a loose, open terminal cluster of spreading stars, pale lavender, just not white, though now and then one may find a deeper tint. Each flowerhead bears eight to fifteen rays, each half an inch long, which gives a spread of about an inch and an eighth to the head. The general effect of this inflorescence is fairly stable. These leaves of $A$. undulatus of ten simulate those of 
A. prenanthoides and of A. cordifolius, but both of these have smaller and more thickly set rays, making smaller stars.

However, one cannot escape the conclusion that all three hybridize more or less, so that determination of species, after all, is pretty much a matter of averages.

\section{LARGE-LEAVED ASTER \\ Aster macrophýllus}

Native, perennial. A pale lilac Aster noticeable because of the large colonies marked by its basal, heart-shaped leaves, three to five to each root. Found in moderately dry soil and shaded places. Maine to South Carolina and west to Minnesota. August-September. Somewhat variable.

\section{Roots.-Long, thick.}

Stem.--Simple, stout, angular, reddish, two to three feet high.

Leaves.-Basal leaves, large, thick, rough, heartshaped, coarsely serrate, acute; standing four to six inches high upon stout petioles. Upper stem-leaves 


\section{COMPOSITE FAMILY}

ovate, pointed, almost sessile; lower stem-leaves heartshaped with margined petioles.

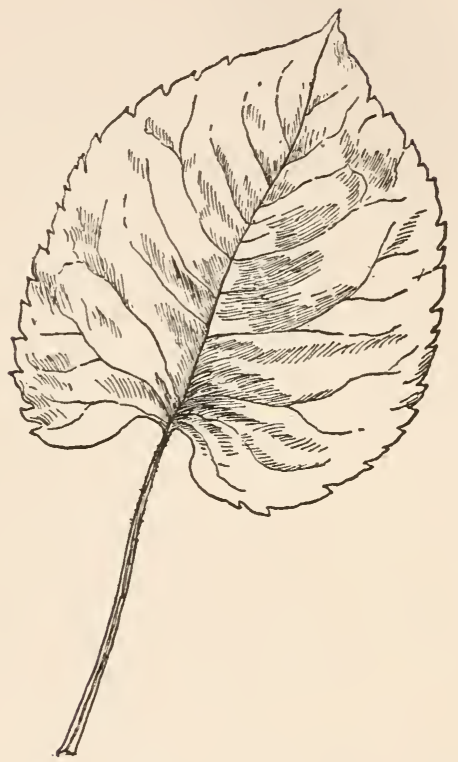

Leaf of Large-Leaved Aster. Aster macrophýllus. + to 8 in. long

Flower-heads.-Lavender, pale violet-blue or white, about an inch across; borne in stiff corymbose irregular clusters. Rays twelve to sixteen; disk-florets turn reddish brown as they fade. Involucre cylindrical; bracts 80 
in three or four rows, conspicuously green-tipped. Pappus white.

Often in open woods one comes upon patches of large, heart-shaped leaves, six to ten inches long, and standing four to six inches high, and one wonders what the plant that grows so gregariously really is. By late August the question is answered, for here and there amid the leaves arises an erect, rigid stem, bearing a corymbose cluster of pale lavender or white Asters, with spread of flower about an inch. The rays vary in size, and the effect of the flower-head is ragged and unkempt.

\section{SMOOTH-STEM ASTER \\ Aster làvis}

Native, perennial. A violet-blue Aster common in dry soil along roadsides and in open woods. Maine to Ontario, southward to Georgia and Missouri. August-October.

Stem.-Rather stout, two to four feet high, branched or simple, smooth, often glaucous.

Leaves.-Thick-textured, pale green, sometimes glaucous, four to seven inches long, smaller as they 
ascend the stem. Oblong-lanceolate, more or less serrate, or rough-margined. Upper leaves usually heart-shaped at base, clasping the stalk, the lower ones taper into winged petioles, which are partly clasping.

Flower-heads.-Borne in a terminal cluster, violetblue, rarely white, an inch across. Ray-florets fifteen to thirty. Involucre bell-shaped; bracts in several rows.

This Aster may be recognized by its thick, smooth, clasping leaves, and often stands so near the roadway as to be covered with the dust of passing wheels.

\section{LATE-FLOWERING ASTER}

Aster pàtens

A showy deep violet-blue Aster, preferring dry places. Maine and Minnesota to Florida, Louisiana and Texas. August-October, blooming at the north principally in October.

Stem.-One to three feet high, with wide-spreading branches.

Leaves.-Rough - pubescent, oblong - lanceolate or ovate-oblong, entire, acute or the lowest obtuse, clasping by an eared heart-shaped base, two to four inches long. 
Flower-heads.-Showy, mostly solitary, terminating the slender branchlets, more than an inch across; rays

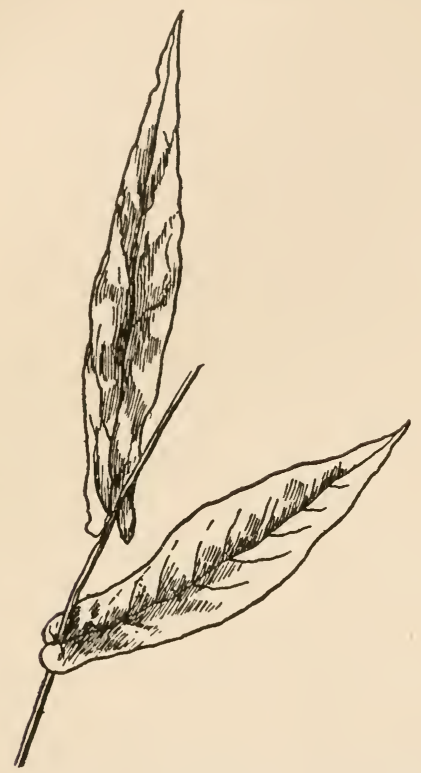

Leaves of Late-Flowering Aster. Aster pdicns

fifteen to twenty-five, about half an inch long, deep violet or violet-blue.

A most attractive Aster which in northern Ohio blooms, as its name indicates, late in the 83 
season, but as it virtually has a continental distribution its blooming period varies.

It possesses one engaging characteristic, its violet heads are mostly solitary at the tips of the many spreading branchlets of the terminal panicle, so that each has its own outlook upon the world. The leaves vary in length, in moist places becoming long and narrow.

\section{BLAZING STAR}

Lacinària scariòsa. Liàtris scariosa

A tall, stout, handsome plant, standing in dry situations by roadsides and in fields, bearing heads of brilliant rose-purple flowers. Perennial. Extremely variable. New England to Minnesota, south to Florida and Texas.

Stem.-Tall, hairy, two to four feet high, simple.

Leaves.-Alternate, narrow, oblong-lanceolate, upper leaves small.

Flower-heads.-Discoid-composite, that is, all the florets tubular, bluish purple, thirty to forty florets in a head, and heads borne on a long spike. Involucre of many dry and scarious scales. Pappus of capillary bristles. 


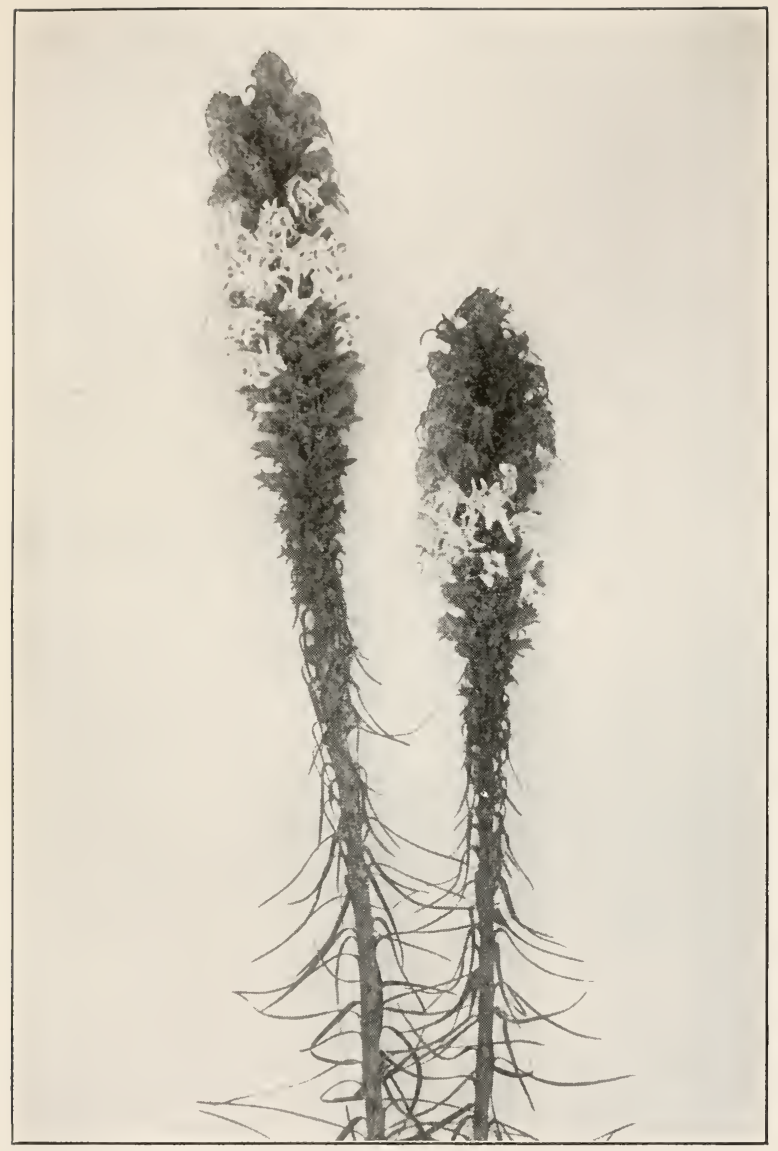

Garden Form of Blazing Star. Liàtris 

The showy wands of Blazing Star blossom with the Goldenrods and Asters in late summer. The flower-heads, varying from magenta-purple to violet-blue, crowd upon the summit of the rigid unbranched stem to form a lengthened spike.

These flower-heads contain from thirty to forty closely packed tubular florets, and sit in a leafy involucre that has five or six rows of long, bristly, purple-tipped scales.

\section{NABALUS. WHITE LETTUCE. RATTLESNAKE ROOT \\ Nábalus}

A group of native perennial herbs, blooming throughout October and noticeable for their graceful drooping bell-shaped heads of rayflorets.

Stems.-Tall, slender, green, sometimes purplish, leafy, with extremely variable leaves, and racemosepanicled nodding flower-heads.

Leaves.-Varying in species from $N$. albus with angulate or triangular-halberd form, sinuate-toothed, or 


\section{COMPOSITE FAMILY}

three to five cleft, to $N$. altissimus, with leaves heartshaped or triangular-toothed or cleft. Very variable.

Flower-heads. - Ligulate-composite, that is, all florets are rays. Bell-shaped, nodding, greenish or yellowish

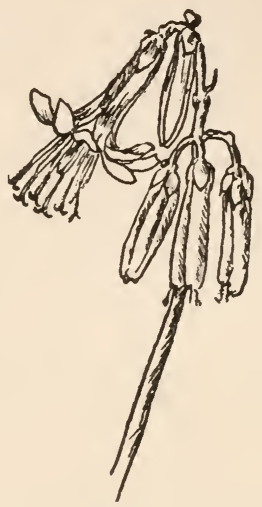

Flowers of White Lettuce. Nábalus

white, dull reddish sometimes flushed with lilac. Borne in terminal panicles and axillary clusters. Rays five to fifteen. Involucre cylindrical, green or dull red, usually narrow; its bracts in one or two series; rays greenish white or cream color, extending beyond the bracts and curving outward forming a pendulous bellshaped head. Pappus varies in species from cream white to reddish brown. 


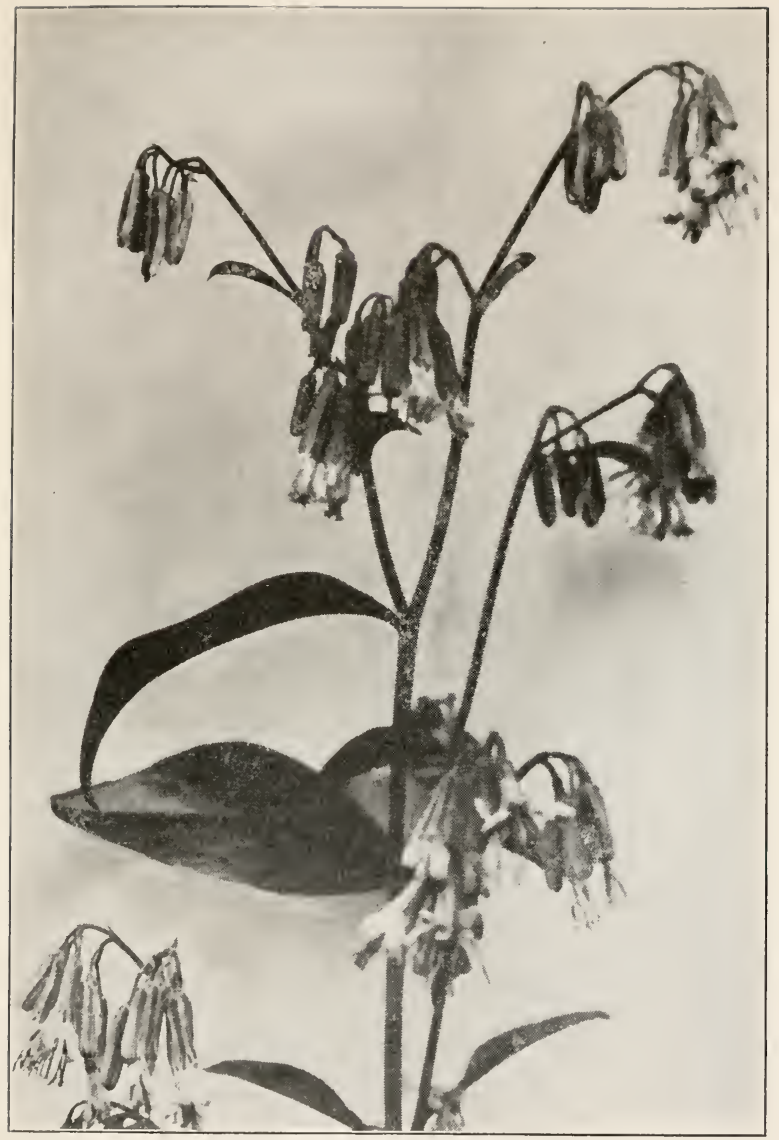

White Lettuce. Nábalus 

By early August Nabalus in varied forms is beginning to press forward to the blooming line. It stands a leafy wand, stout and sturdy or graceful and waving, by the road through the wood or in the open, where shade may reach it at some time during the day. It stands as earlier in the season the Wild Lettuce stood just before it developed its bushy head of pale yellow florets and white downy pompons. But Nabalus, curiously enough, has departed from the composite type of flat flower-heads held up to the sun after the manner of Daisy and Aster, and has fashioned from its enclosing bracts its slender rays and long styles a most dainty exquisite bell, greenish yellow often flushed with lilac. These bells hang in nodding clusters of three or four. Several species occur along woodland ways, with leaves so variable that one saves time to wait for the bloom in order to determine the individual, for the fairy bells never fail to ring both name and season. In one species the involucre bracts are dark rich red though the flowers are cream. 


\section{COMPOSITE FAMILY}

\section{WHITE EUPATORIUM. WHITE SNAKEROOT}

Eupatòrium ageratoides

Native, perennial. A very beautiful lateblooming White Eupatorium, found at the edge of woods or in any half-shaded place. Nova Scotia to Georgia, west to Nebraska and Oklahoma. August-November.

Stem.-Smooth, branching, two to four feet high.

Leaves.-Opposite, long-petioled, broadly ovate, triple-nerved and veiny, coarsely and sharply toothed, acute at apex, square or heart-shaped at base, three to five inches long.

Flower-heads. White, in corymbose clusters. All florets tubular and perfect, from ten to twenty in a head. Involucre bell-shaped. Pappus white.

Three autumn blooming plants bear flowers that for beauty and delicacy equal the rarest of spring's darlings. Grass of Parnassus ranks with Hepaticas, Bloodroots, and Spring Beauties; Lady's Tresses in their rare patrician loveliness are indeed ladies of high degree, and the 


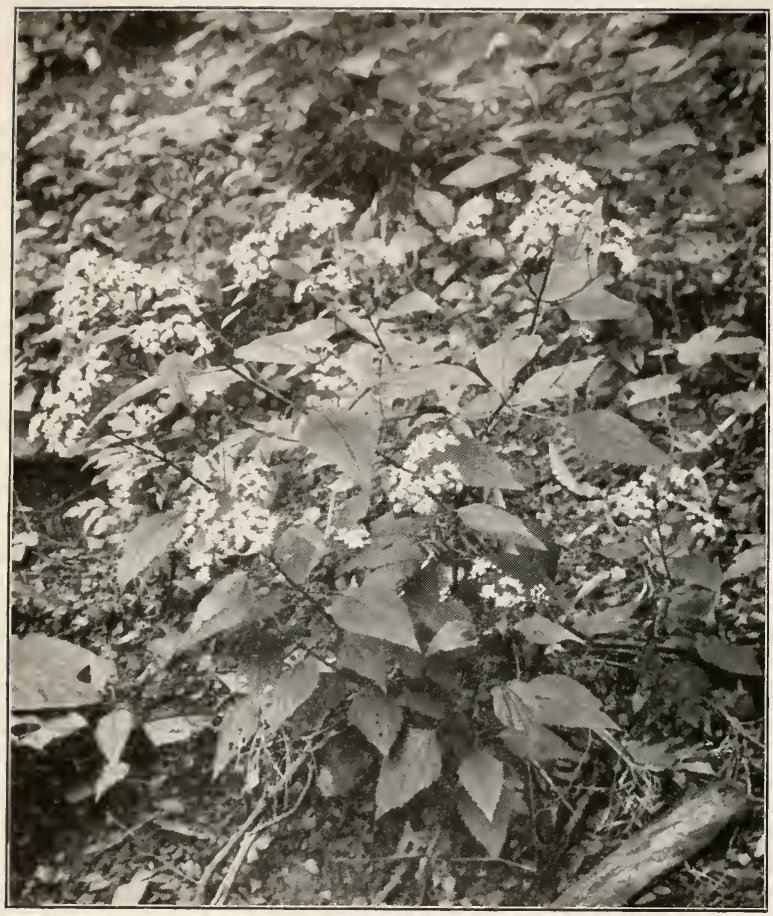

IThite Eupatorium. Eupatorium ageratoides 

third place may be given without question to the White Eupatorium.

The plant is shade-loving, is to be looked for in the shadows of the woodland, back perhaps from the edge ten to a hundred yards, wishing for the protection of the trees yet longing for light. The delicacy of its soft, misty, white clusters of composite heads suggests a flower of spring, yet its bloom is abundant in September, and it belongs to the genus which contains Joepye Weed and Boneset.

These soft clusters are made up of many little heads, composed of tubular florets only, each of which puts forth a slender style which gives a white fringe effect to the cluster. 


\section{LEGUMINÒSE Æ-PEA FAMILY}

\section{WILD PEANUT}

Falcàta comòsa. Amphicarpèa monòica Falcata, referring to the curved keel of the corolla. Amphicarpæà, Greek, meaning seed at both ends.

Native, a twining perennial vine with threeparted leaves, bearing pea-like blossoms, violet and white, in axillary racemes, as well as cleistogamous flowers. Edge of moist thickets, roadsides. Massachusetts, westward and northwestward to the Dakotas. August-October.

Stem.-Rather stout, covered with reflex brown hairs; twining and trailing, forming matted beds.

Leaves.-Alternate, three-foliate with oblong or ovate stipules. Leaflets, broadly ovate, acute, rounded at base, entire at margin.

Flowers.-Papilionaceous, in axillary racemes, pale violet and white; small flower bracts orbicular, downy. Cleistogamous flowers near the base and on creeping branchlets.

Calyx.-Tubular, four-toothed, whitish. 


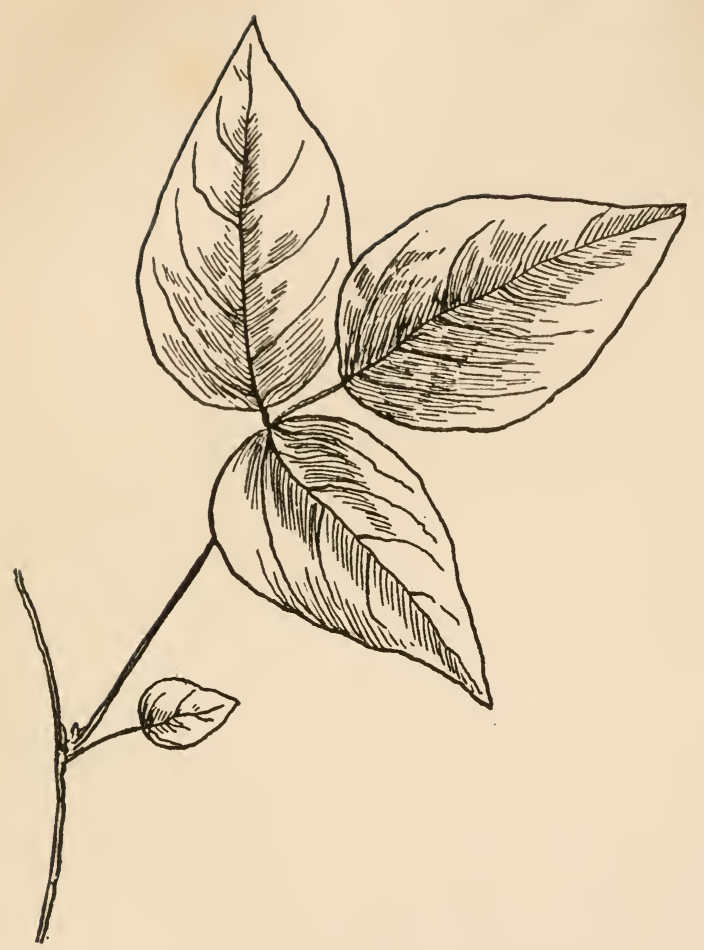

Leaf of Wild Peanut. Falcdita comdsa

Corolla.-Standard erect, obovate, folded around the other petals, pale violet; wings usually white, oblong, adherent to the keel which is curved and white. 


\section{PEA FAMILY}

Stamens.-Diadelphous, nine and one, filament tube and single filament white.

Pistil.-Pea-like, style filiform not bearded.

Fruit.-Of two kinds: pods from the upper flowers linear-oblong, several-seeded, two-valved; pods from cleistogamous flowers, mainly one-seeded and subterranean, small, round, and white.

Early in autumn one often finds great beds of the pretty three-leaved vine of the Wild Peanut, twisting its stems about every available weed, or trailing off in to the grass and spreading them a twining mass upon the ground. The leaves are pale in color, thin of texture, and dull of surface.

The plant is interesting in that it bears two kinds of flowers: a pretty little lilac pea in a nodding raceme which, however, with all its dainty beauty rarely ripens a pod, and the other a bud-flower, cleistogamous, a flower that does not open; on the contrary, at flowering time it drives the pistil as far as it can underground, that the pod may mature there; in this way doing just what the real Peanut does, from which 
it gets the name Wild Peanut. The bloom begins in August, but the leafy bed has been conspicuous all summer. A trailing stem uprooted in late September is tolerably sure to have upon it a few of the ground-seeking pods, small, white, and round. 


\section{SGROPHULARIÀCE E-FIGWORT FAMILY}

\section{PURPLE GERARDIA}

Geràrdia purpurea

Gerardia, named in honor of John Gerarde, an English herbalist.

A native annual found in moist soil, generally near the coast or in the vicinity of the Great Lakes, having showy purple flowers. Maine, south along the coast and west to Minnesota. August-October.

Stem.-One to two feet high, with rigid, widely spreading branches.

Leaves.-Opposite, the upper alternate, linear with acute tips, one to two inches long, rough-margined.

Flowers.-Showy, large, varying from bright purple to purple-pink and white, about an inch long, borne along the rigid branches.

Calyx.-Bell-shaped, five-toothed; teeth short.

Corolla.-Funnel-form; tube much inflated and spreading into five, unequal, rounded lobes, spotted within and sometimes downy. 
Stamens.-Four in two pairs, included; filaments hairy; anthers approaching by pairs.

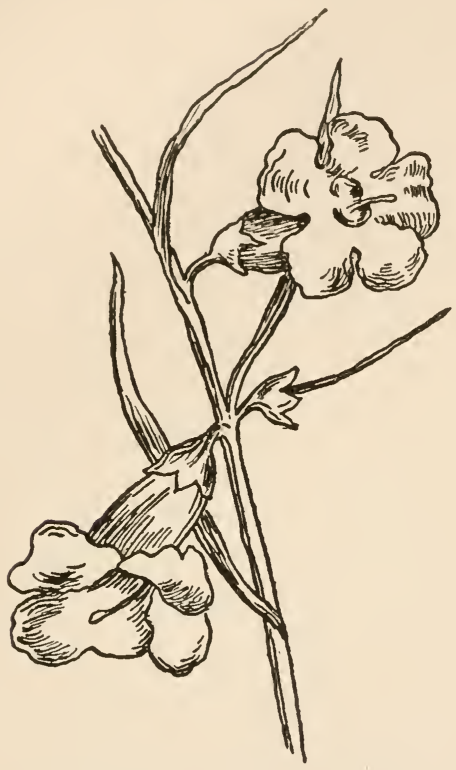

Purple Gerardia. Geràrdia purpùrea

Pistil.-Ovary ovate, many-ovuled; style elongated, flattened at apex.

Pod.-Globular, many-seeded.

Pollinated by bees and butterflies. Nectar-bearing. 95 
Low-lying meadows of New England along the coast are frequently tinted by the Purple Gerardias growing among the grass. Certain sandy fields of Long Island are of ten a mass of vivid color owing to the numbers of these delicate blossoms. The rosy flowers are cup-shaped, with five flaring lobes; within are four downy stamens with rather large golden anthers.

The Seaside Gerardia, Gerardia maritima, is a smaller species, four to twelve inches high, found along the coast usually in salt marshes; color a pale rose-purple.

Slender Gerardia, Gerardia tenufolia, is a mountain form native to dry woods and thickets. Its color is pale rose-purple varying to white, marked with many blurred spots. Two of the five lobes are not fully expanded.

All the Gerardias bear beautiful flowers, and their time of bloom extends from midsummer to late autumn. They are supposed to be more or less parasitic in their habits, drawing some nourishment from the roots of other plants. 


\section{GENTIANĀGE E-GENTIAN FAMILY}

\section{FRINGED GENTIAN}

\section{Gentiàna crinita}

Named in honor of Gentius, king of ancient Illyria, who is said to have discovered its medicinal qualities.

Native, a winter annual or biennial. The most beautiful and appealing of our autumn flowers; a late bloomer to be looked for in low moist pastures and meadows. Delicate, elusive, and lovely beyond belief. New England to Minnesota and south to Georgia and Iowa. September, October.

Stem.-One to three feet high; branches erect, leafy, smooth, angled, and grooved.

Leaves.-Basal leaves obovate, obtuse. Stem-leaves opposite, oblong-lanceolate, acute or acuminate, sessile or clasping with a heart-shaped base, margin entire.

Flowers.-Solitary, blue, borne on the tips of either long or short branches.

Calyx.-Tubular, four-ridged and four-cleft; lobes lanceolate, acuminate. 
Corolla.-Beautiful blue with violet tints, narrowly bell-shaped, one and a half to two inches high, fourparted, the obovate spreading lobes fringed around the edge. These lobes are very sensitive, opening widest in clear, direct sunlight, and closing at night with a curious little twist.

Stamens.-Four, inserted on the tube of the corolla, included.

Pistil.-Ovary one-celled; stigma two-cleft; ovules many. Pollinated by bees.

"October: Somewhere, now, the Fringed Gentian is blooming. Because it is one of the most beautiful it has become one of the rarest of our native wild flowers. Whoso sees it destroys it. It is an annual, wholly dependent on its seed for propagation, and each blossom that is plucked brings the fringed gentian a little nearer to extermination.

"There are many lovers of the open who have sought year after year for the fringed gentian. Their search has never been rewarded, and they have become quite certain that it never will be rewarded. But each year they go forth to seek, finding pleasure in the quest of the unattainable. Sometime, somewhere, they may by merest chance come upon the more than heavenly blue of the priceless jewel of the autumn.

"The fame of the gentian is, therefore, indirectly beneficial. It is one more reason for an outing in the year's best outing time.

"The tragedy of the gentian should teach a practical lesson. To destroy a thing merely because it is beautiful is the worst tribute to nature's excellence. Very few 


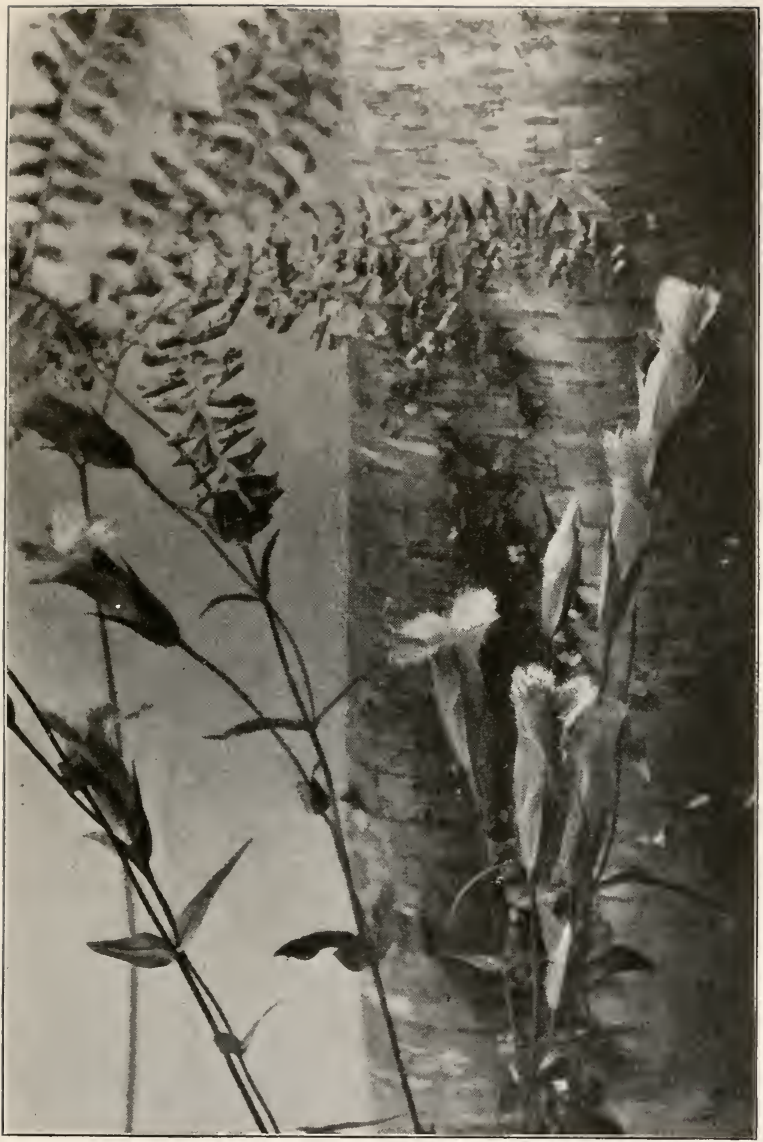

Fringed Gentian at Home. Gentiana crinita 

flower lovers or mere heedless wanderers would deliberately deprive their children of the pleasure of a rare flower. Thoughtlessness rather than wanton destructiveness has been the bane of the fringed gentian, as it has been the bane of some others of the more beautiful of showy flowers. It is a safe prediction that a sincere searcher, who may, after many autumns of disappointment, actually find a fringed gentian, will leave it unplucked and be happier for his forbearance.

"Is this gentian truly the most beautiful of all our wild flowers, or is it too dearly esteemed because of its rarity and because of its whimsical blossom time? It is not a question of importance. It is certain, and always will be certain, that whoever finds this priceless jewel of October will be content in the assurance that no other flower can match its beauty.

"The fringed gentian is incomparable and indescribable. It is like no other flower, and its beauty defies the skill of the word artificer. Bryant tried to depict the fringed gentian in verse, and the result was a very pretty poem, but it did not give even a hint of the gentian's fairness. It can be appreciated only by the October rambler who has found it in its home. Gathered and borne away, its wonderful petals soon close in despair, and the loveliness of the October hillside cannot be transferred to the vase in the drawing-room.

"Here it is, right by the roadside, where the automobiles whiz past. The people in the automobiles have plucked great bundles of the showy New England asters, but they have sped blindly past the lowly gentians. Humility and tardiness are the gentian's only protection. It is so late 


\section{GENTIAN FAMILY}

that the hasty wayfarer expects nothing so dainty and vernal and seldom notices it at all. It is the boldness of innocence that inspires the fringed gentian to establish itself right at the side of the path of the thoughtless. Any October a little band of discerning vandals might destroy it utterly, for it is an annual, and where it is once destroyed it appears no more. Yet it has bloomed here year after year, and no one has noted it except the rambler whose devoutest prayer is that it may not be noted."

-Carl T. Robertson.

\section{CLOSED GENTIAN. BOTTLE GENTIAN,}

Gentiàna andréwsii

Native, perennial. Bears flowers of a deep clouded blue, and grows in wet, weedy places. Common. Quebec to Northwest Territory, south to Ohio. August-October.

Stem.-Two to four feet high. Smooth, stout, often stained with purple.

Leaves.-Opposite, ovate to lanceolate; upper leaves sessile, entire, lanceolate, with midrib only prominent.

Flowers.-Dull purplish blue, an inch or more high, set in clusters at the summit of the stem and in the axils of the leaves. Occasionally pure white throughout.

Calyx.-Five-lobed; ovate, green touched with purple. 


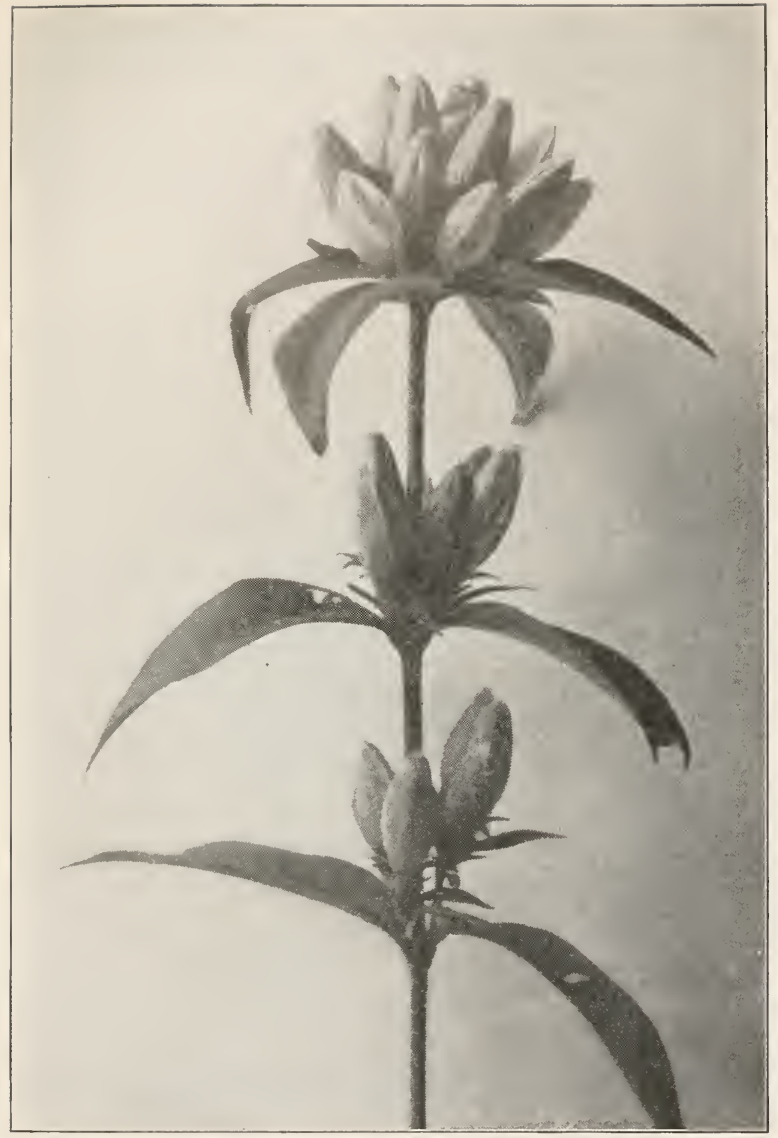

Closed Centian Gentiána andréwsii 

Corolla.-Oblong, club-shaped, bulging, an inch long, dark blue at summit, paler in the middle and toward the base. White lines at the mouth. Lobes plaited so as to make a closed top, intervening appendages slightly lobed; creases run half-way down to the base.

Stamens.-Five, inserted on the tube of the corolla. Anthers mature before stigma.

Pistil--Ovary one, large, flattened, oblong; stigmas two; ovules many.

Pollinated by bumblebees.

The corolla of this Gentian is so definitely closed against intruders, folded over at the top so like the pocketbooks warranted to keep silver coin from straying, that interest is at once aroused as to what really is inside that is so carefully guarded. Pushing one's way past the closed door, possibly cutting down one side of the floral wall, the inner treasures are revealed. First of all is a large, pale green ovary, threequarters of an inch long, surmounted by two white balls of stigmas and filled with an astonishing number of ovules. Its size is such that no wonder the corolla bulges, it has to. Attached to the inner walls of the corolla are five 


\section{GENTIAN FAMILY}

stamens with slender filaments and anthers converging.

So closed is the corolla of this Gentian, that it was long supposed to be self-fertilized. Later, it was discovered that the bumblebees fertilized it. Neltje Blanchan, in Nature's Garden, writes of the problem as follows: "Now, how can a bumblebee enter this inhospitable-looking flower? If he did but know it, it keeps closed for his special benefit, having no fringes or hairs to entangle the feet of crawling pilferers, and no better way of protecting its nectar from rain and butterflies. Watch him alight on a cluster of blossoms. . . With some difficulty, it is true, he thrusts his tongue through the valve of the chosen flower where the five plaited lobes overlap one another; then he pushes with all his might until, his head having passed the entrance, most of his body follows, leaving only his hind legs and the tip of his abdomen sticking out as he makes the circuit. He has sense as well as muscle, and does not risk imprisonment in what must prove a tomb by a total and unnecessary 
disappearance within the bottle. Presently he backs out, brushes the pollen from his head and thorax into his baskets, and is off to fertilize an older stigmatic flower with the few grains of quickening dust that must remain on helvety head."

Five-Flowered or Stiff Gentian, Gentiàna quinquefolia has its small five-parted blue-pointed flowers arranged in clusters not exceeding seven at the end of the branches or seated in the leaf axils. The slender branching stem may rise only two inches in dry soil, perhaps two feet in rich, moist, rocky ground, where it grows to perfection, especially in mountainous regions. From Canada to Florida and westward to Missouri is its range, and its time varies from August to October. 


\section{PARNASSÍACEÆ-GRASS OF PARNASSUS FAMILY}

\section{GRASS OF PARNASSUS \\ Parnássia caroliniàna}

Parnassia, a name given by Dioscorides because certain species grew upon Mt. Parnassus.

A native, perennial herb, flowering in September, mostly in wet places. New England to Wisconsin and southward, especially along the mountains.

Stem.-Six to twelve inches high.

Leaves.-Basal leaves thickish, ovate or rounded, form a rosette. Stem-leaf one on a stalk.

Flowers.-Silver-white, solitary, terminal.

Calyx.-Five-lobed, slightly united at base.

Corolla.-Petals five, oval, spreading, white with green veins.

Stamens.-Five perfect stamens; imperfect stamens, that is filaments with no anthers borne in clusters at the base of each petal.

Pistil.-Ovary one-celled; style one; stigmas four.

Fruit.-Capsule, seeds many. Seed-coat winged. 


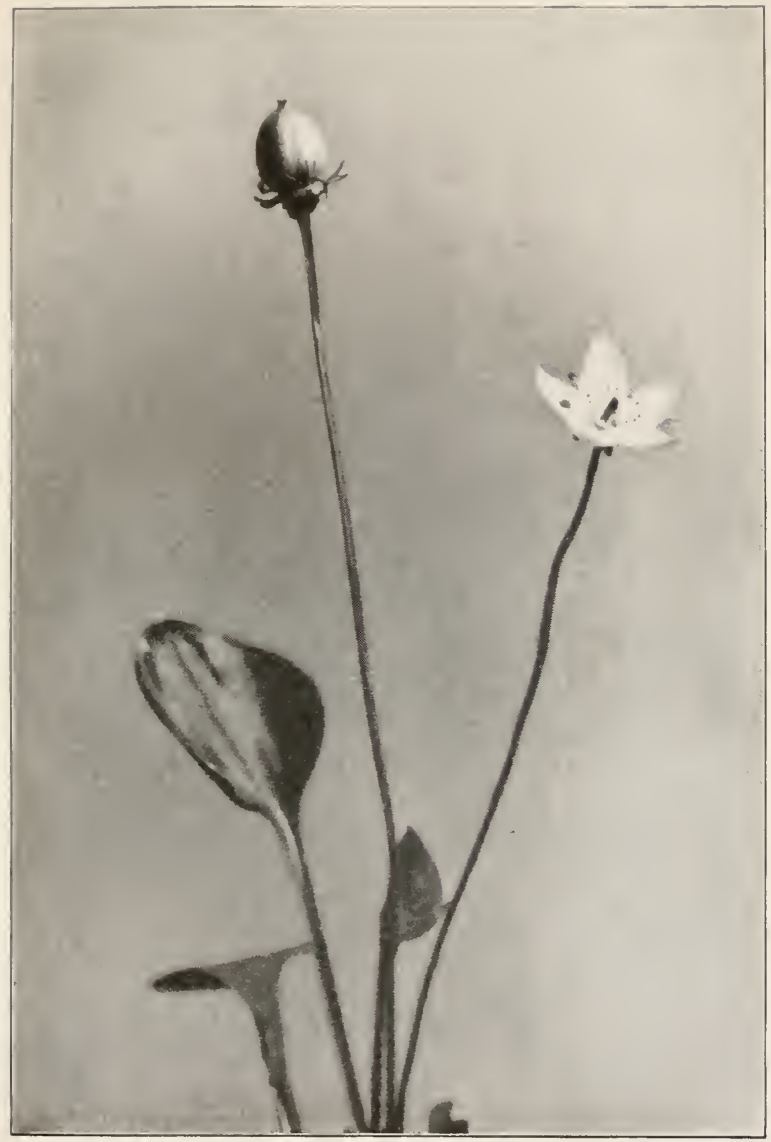

Grass of Parnassus. Parnássia Caroliniàna 

It is an experience when one is out for Goldenrod or Asters to come upon a delicate white flower blooming under the drip of a rocky ledge, apparently at home. It looks like a flower of spring, yet we know it is not. Its romantic name appeals to us and seems classic, scholarly, and altogether appropriate, but to the Greek botanist who named the plant, it was simply a statement of fact; it grew on the flanks of $\mathrm{Mt}$. Parnassus.

When all is said one still feels that properly it consorts with the mist and softness of springtime, not with the hardness and brilliancy of autumn. Its delicate white petals are definitely veined with green, its five perfect stamens are surrounded at base with a cluster of filaments without any anthers, the flower stem rises from a rosette of succulent green; clearly its title is one to be read in the spring.

"The beauty of the bloom of Parnassia is quite indescribable. She is white, but she is neither snowy nor silvery nor creamy. She has a soft grayishness that is fairer than utter purity. 


\section{GRASS OF PARNASSUS FAMILY}

Each lovely petal is streaked with many pale green lines, guide paths for the insects that are invited to the feast of nectar. The whole is elevated high on a fragile stem. Thousands of these stems spring from the Parnassian bog. From the railroad embankment the swamp seems but a wide spread of leucanthous allurement." 


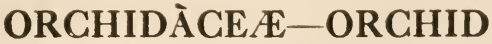 FAMILY}

\section{LADY'S TRESSES}

Spiranthes cêrnua. Gyróstuchys cêrnua

Spiranthes, Greek, from speira, a curl, and anthus, flower.

Native, perennial. An orchidaceous plant, bearing small white flowers in three ranks, closely crowded, and more or less spirally twisted, variable. Nova Scotia to Florida, Minnesota, New Mexico, and Louisiana.

Stem.-Leafy below and leafy-bracted above, six inches to two feet high, often nodding.

Leaves.-Linear-lanceolate, variable, usually disappearing before the flowering season.

Flowers.-Of the orchidaceous type, small, pure white, sweet-scented, three-ranked, borne on a slender cylindrical spike about which they curve in a spiral twist.

This is the last Orchid of the season to blossom, and companions the Fringed Gentian and the Witch Hazel; it may bloom earlier, but the 


\section{ORCHID FAMILY}

blooming period lasts into late October in wet meadows and grassy swamps.

The characteristic twist that lies deep in the nature of every Orchid shows itself here, not only in the twist of the ovary, which turns the flower upside down, but also in the peculiar spiral form with which the three ranks of small white flowers wind themselves around the flower stem. It grows from six to twenty inches high, and earlier in the season had leaves, but they usually disappear before the flowering period. Spiranthes cernua is a lady of three tresses, while there are several of the group who have but one, notably Spiranthes grácilis, who lives in dry fields and open woods, and wanders at will from Nova Scotia to Minnesota and southward to Louisiana and Florida. 


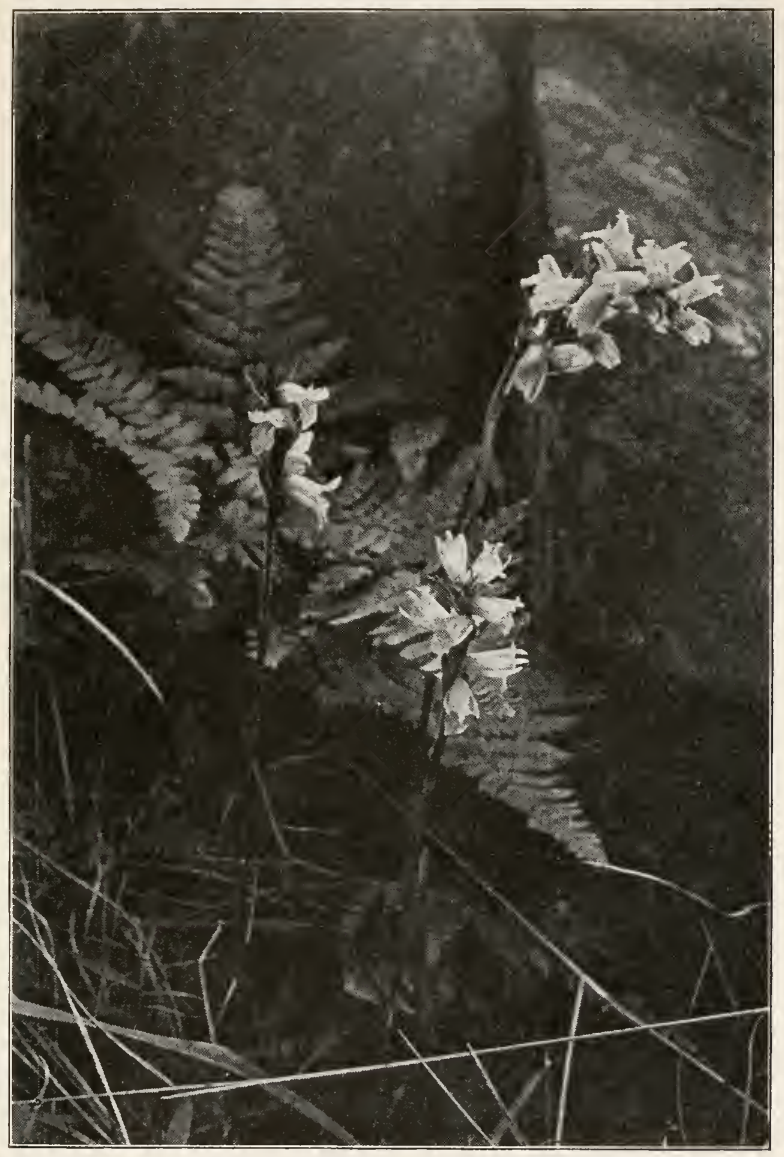

Ladies`Tresses. Spiranthes círnua 



\section{MORĀGE $ૈ$ MULBERRY FAMILY}

\section{WILD HOP}

Hùmulus lìpulus

Humulus, said to be a diminutive from humus, earth.

A rough herbaceous perennial vine, found in thickets and on river banks, preferring alluvial soil. Nova Scotia to Manitoba, in the Alleghanies to Georgia, and the Rockies to New Mexico. Indigenous, cultivated, and extensively escaped from cultivation. Of intercontinental distribution.

Stem.-Ten to thirty feet long, very rough with stiff reflexed hairs.

Leaves.-Opposite, petioled, orbicular or ovate in outline, deeply three to seven-cleft, or some of the upper ones ovate, acute, and merely serrate.

Flowers.-Diœcious, axillary; the staminate flowers in panicles; the pistillate in drooping clustered spikes that look like aments. Staminate flowers with a fiveparted calyx and five short stamens. Pistillate flowers in twos at the base of each bract of the ament, and consist of a perianth clasping the ovary and two threadlike stigmas. 
Fruiting Aments.-Look like hemlock cones, pale yellow-green; at the base of each yellow bract, and covered by it, are two akenes, yellow, covered and dotted with yellow resinous aromatic glands.

The Wild Hop is an extremely interesting plant. In midsummer it is lost in the green of the thicket, or unobserved as it climbs up out of the tangle and into the sunlight, but when the soft mellow rays of September come and one goes afield its gold-green clusters of Hops festoon the topmost branches of the thicket, cover and adorn the rugged stump or the unsightly fence.

The fruiting cone-like spike consists of many thin, concave, yellow-green bracts. Covered and secure against harm at the base of each are two yellow seeds, thickly sprinkled with aromatic resinous dots. The more of these the better the fruit, for it is they that give the value to the Hop for beer-making, and supply the aromatic bitter that is so highly regarded. 


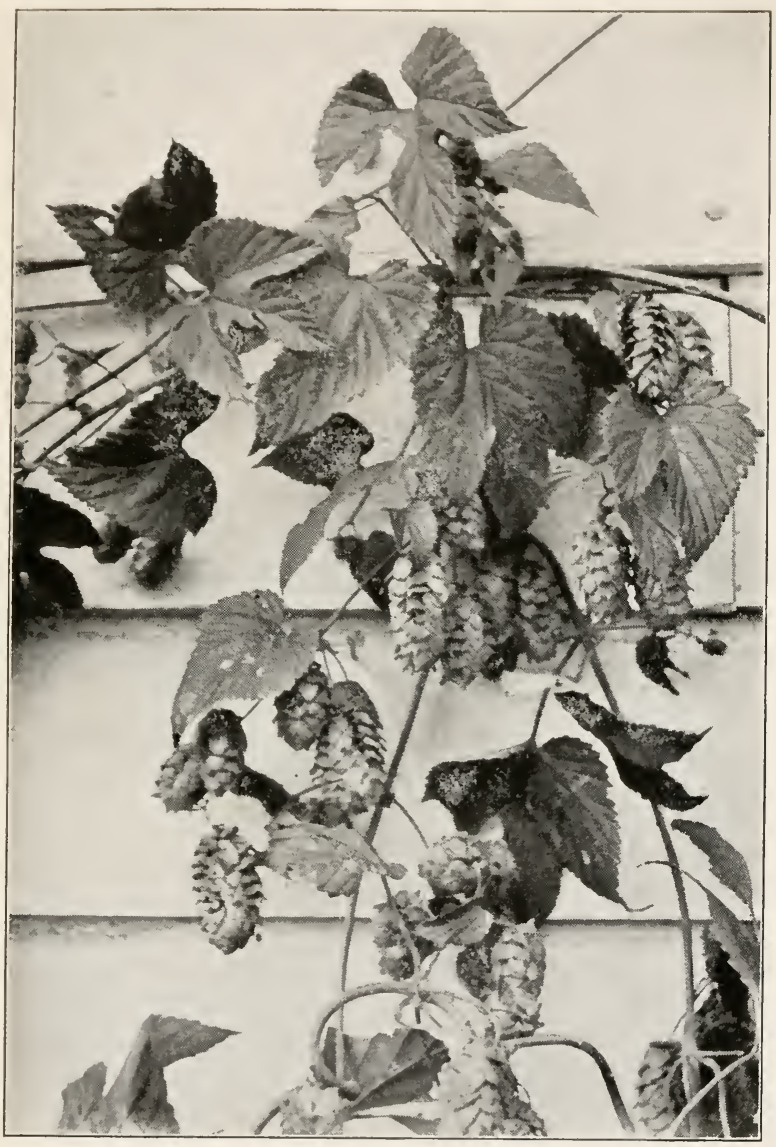

Wild Hop. Irimulus lìpulus 



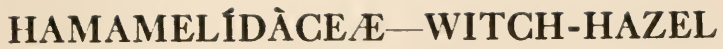 FAMILY}

\section{WITCH HAZEL \\ Hamamèlis Virginica}

A small tree or stout shrub found in low, rich soil; one of the underwood trees of the forest. Blooms in one autumn and its fruit ripens the next. Nova Scotia to Nebraska and south to Florida and eastern Texas. Bark, twigs, and leaves used in making extract for bathing bruises.

Bark.-Light brown, scaly or smooth.

Leaves.-Alternate, oval or obovate, wavy-margined or coarsely serrate.

Flowers.-Yellow, in axillary clusters, surrounded by a scale-like, three-leaved involucre. Calyx four-parted, with two or three bractlets at base. Corolla with four strap-shaped petals, long and narrow, spirally involute in bud. Stamens eight, very short, four anther-bearing, the others imperfect. Styles two, short. Pod en- 
closes a large and bony seed in each cell, opens elastically and projects the seeds.

Julia A. Rogers, writing of the Witch Hazel, says:

"Every tree has its supreme moment of beauty. This usually comes when the foliage is in its prime or when the flower buds burst in spring. The Witch Hazel is an exception to all rules. When the crisp autumnal atmosphere warns all plant life to get ready for winter, the Witch Hazel puts a new construction on the message. As if by magic all up and down through the woods they burst into bloom, each flower bravely flaunting four delicate petals like tiny yellow streamers. The woods are fairly sprinkled with these starry, gold-thread blossoms, and a rare fragrance breathes upon the languid October air. The ripening leaves second and intensify the color of the flowers, which of ten thickly fringe the outstretched twigs and cover up the green fruit-buttons.

"It is a far cry from March to October; from furry tassels of blossoming aspens and willows 

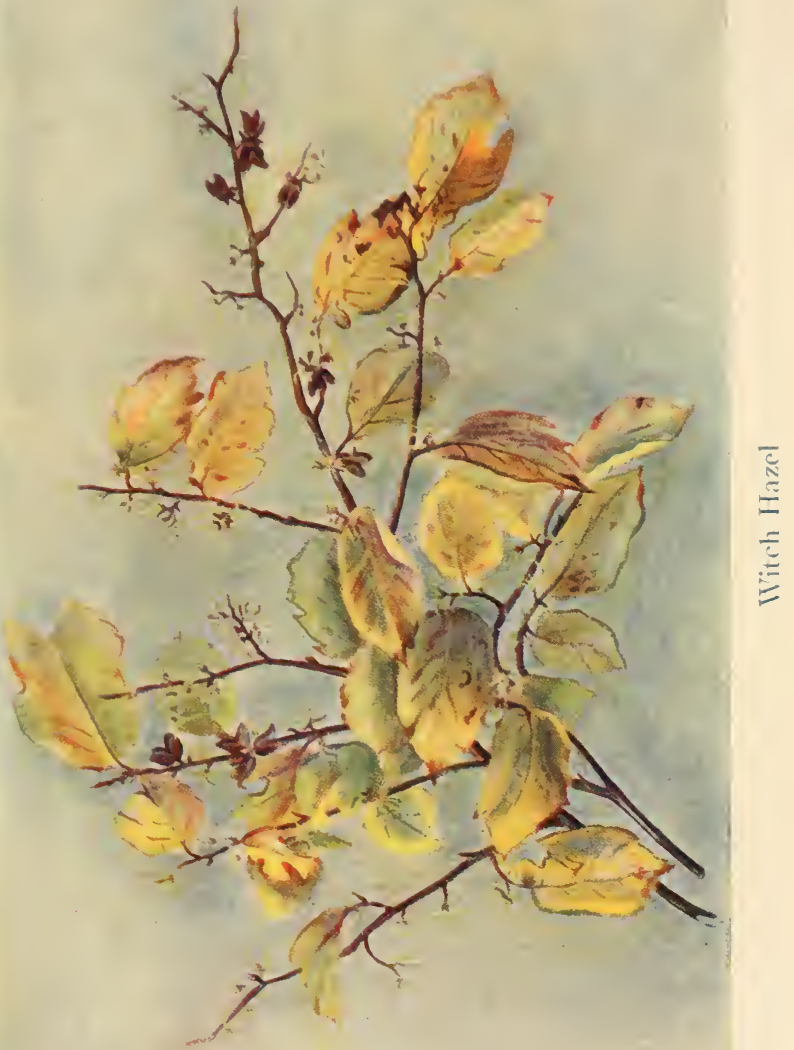

to the Witch Hazel in its yellow blossoms bringing up the rear in the great annual procession of the flowers. In fact, the Witch Hazel practically bridges the chasm of winter, for at no time does the cold cause all the flowers to fall. Their yellow petals curl up like shavings; but they of ten stay till spring.

"A witch in old days was a person who did or said things not conventional. Our Witch Hazel has defied the ancient laws of the calendar - a very dreadful thing! So it comes honestly by its name; and one is inclined to ignore the accepted etymology that the word 'witch' or 'wych' in old English means weak, and refers to the sprawling habit of the tree. Surely the observer cannot miss seeing little weazen witch faces grinning at him from all possible angles of the tree, their yellow cap-strings flying in the wind, as if in defiance of the rumor that the days of witch craft are past."

Sept. 2 I, 1859.

"Heard in the night a snapping sound and the fall of some small body on the floor from time to time. In the 


\section{WITCH-HAZEL FAMILY}

morning I found it was produced by the Witch-hazel nuts on my desk springing open and casting their seeds quite across my chamber hard and stony as those nuts were. For several days they were shooting black seeds here and there about my room."

- Henry D. Thoreau. 


\section{STURDY SURVIVORS OF SUMMER}

The autumnal flora is interesting in that it holds to the poles of life; it bears in its bosom the dying and the dead, at the same time that it welcomes youth, insistent, omnipresent youth, roystering up and down the highways and byways in the persons of the Sunflowers, the Goldenrods, and above all the Asters. These are the favorites of the season, the joy of all our northern autumns, not defiant of winter but heedless of it.

With September well under way one may see along the highway many of the darlings of summer still in sturdy bloom. Placing at the head of the list the fading rather than the opening flowers, the Mullein comes first, for it is just putting forth the last and topmost blossoms on its tall, brown, clumsy spike. Notwithstanding the tradition that the Mullein is known in England as the American Velvet-Plant, it is 


\section{STURDY SURVIVORS}

not indigenous to this country, but came to us overseas. With it the Teasel, a plant fairly well acclimated to the roadside, is opening its last pale blue florets on its long, prickly heads. The Teasel certainly possesses the gift of continuance, for in early summer last year's stalks stand up strong and brown and lusty amid this year's plants.

Butter and Eggs, so named because of the orange and gold of its blossoms, forms blooming beds, and will continue so to do until snow comes; for possessed of a hardy constitution and creeping roots it yields only to winter himself. Two others, companions in vagrancycitizens of the world, free, careless, and happy -are to be found everywhere-Bouncing-Bet and Sweet Clover. Glorious in midsummer, they still linger, depressed but not conquered. Both originally of the garden are to-day outcasts, social pariahs, but instead of minding both are dancing their way across the continent along the railroad tracks. Bouncing-Bet bears a blossom of exquisite rose-pink when first she 


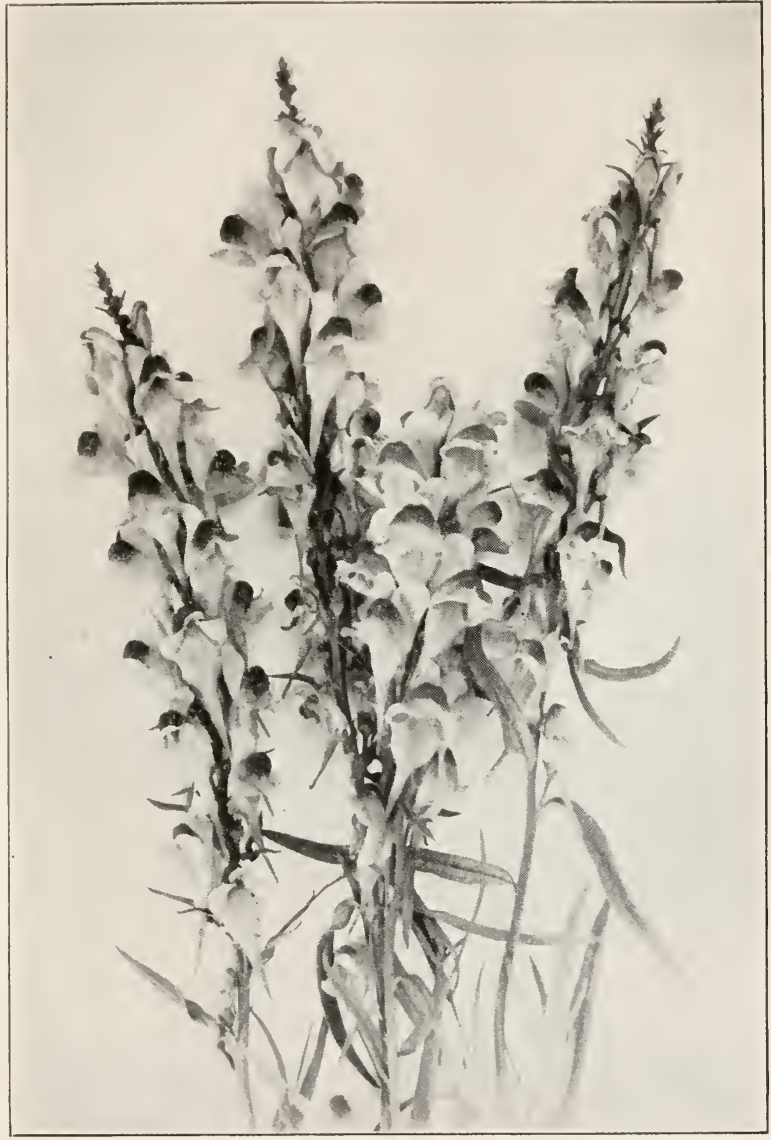

Butter-and-Eggs. Liniria vulgàris 



\section{STURDY SURVIVORS}

opens her petals to the light, but pink is an unstable color in flower tissues, and soon fades. Sweet Clover blossoms are fragrant, heavy with nectar and loved of the bees.

Two beauties, the Great Blue Lobelia and the Tall Blue Vervain, are found in low, moist places until driven away by the very touch of winter. Turtle-Head lingers by the little streams and looks at itself in the water until its mirror is clouded by fallen leaves. Polygonums in variety from Persicaria to Pennsylvanicum stand erect and sturdy, just a little pinker than in midsummer, because each tiny calyx now protects and enfolds a shining seed.

Evening Primrose, a tall leafy weed with two or three yellowish buds, two or three faded yellow flowers, and an array of long, brown seedpods adorning its upright stem, crowds along the highways and fills the neglected fields. Now and then one finds a lusty Primrose with blossoms so wide open, so delicate and fragrant, with leaf and stem so lacking their usual rankness that one wonders what wrought the change. 


\section{STURDY SURVIVORS}

They are the stems that have sprung from a plant beheaded in the spring, and are now blooming in late autumn.

Abundant in the west and everywhere in New England is the Chicory, a sprawling, awkward, weedy plant, whose generally dishevelled appearance is somewhat compensated by the delicate beauty of its blossoms. The pale blue flowers appear singly or in twos, alternate upon the lengthening stems, which have at base a collection of ripening heads, then flowers, then buds. By the end of September the last flower surmounts the stem and surveys the wreck of summer's glory.

Down the brown roads, along with Asters of imperial purple and Goldenrods fit for kings' sceptres, marching in ever-thinning ranks are the stately spires of various Wild Lettuces, on the eve of collapse. With them are a few fullblooming heads of Joe-pye Weed, Boneset, Ironweed, Tansy, Wild Carrot in bloom or in fruit, together with the seedling Yarrow, white and beautiful amid its aged and brown relations, 


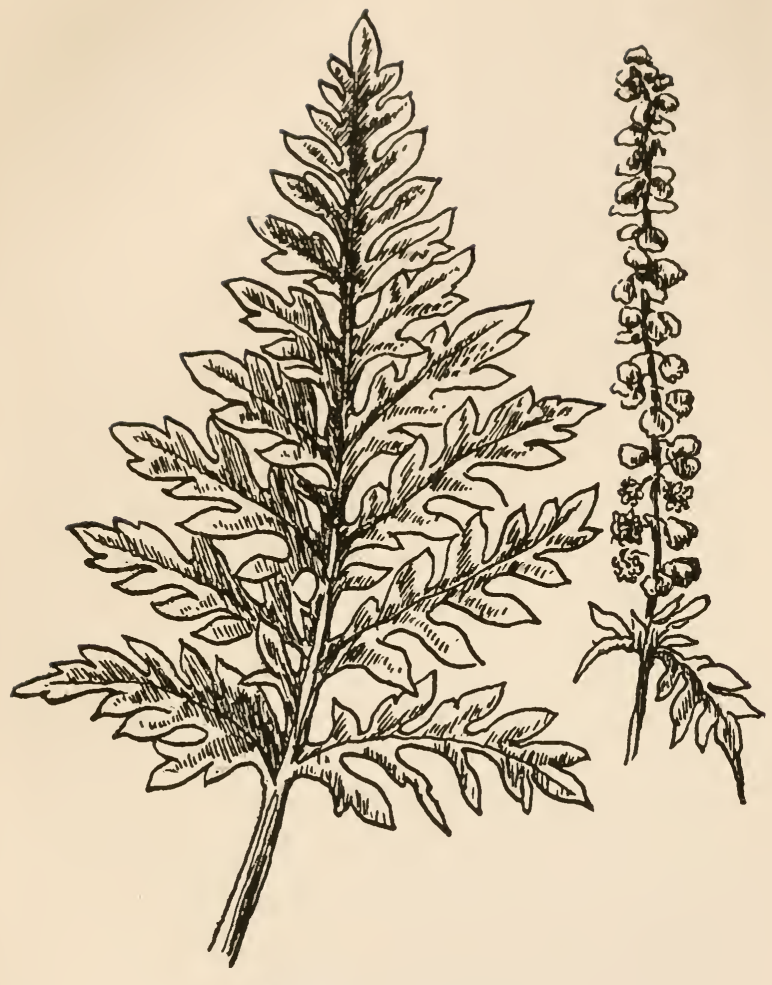

Leaf and Flowers of Ragweed 
also the Everlastings, doing their best to live up to the level of their name-and here and there a Buttercup, glossy and spring-like-all limping a little in the grand procession, but all facing hopefully the future, which is the end.

With them is a motley group that ought not to be, yet nevertheless are. These are plants which in the interests of civilized life should be destroyed. That pest of gardens, Pigweed or Redroot; the Burdock, a brown mass of lifeless stems studded with clusters of brown balls, so fully armed that man and beast transport them in spite of efforts and protests; the Clot-bur, allied to the Burdock, and quite as unwelcome; the tall gaunt stems of the Horseweed, together with the Ragweeds, omnipresent as well as omnieverything else that is unpleasant.

Also the Great Docks, in the procession and also over the fence, the very picture of rude, vigorous life, crowned as they are with their reddish brown spikes of fruit, which need but a ray of sunshine to transform them into flowers. 


\section{STURDY SURVIVORS}

Dodging in and out of the marching line, halting at a barnyard to take possession of every unoccupied foot of space, romping along the roadside at the edge of every tangle is the Mayweed, a tiny daisy-like flower, which would be more attractive had it an agreeable odor. It reaches the height of a foot or more, becomes of bushy habit, and its small leaves, cut and slashed to formlessness, are of disagreeable odor and acrid taste. Tradition says that a certain Englishman, resident in America, introduced the plant, sowing it quite generally lest he should be deprived of his camomile tea. It blooms late, withstands in sheltered places more than one snow-storm, and often shivers its way through November.

There is a group of hardy plants that may well be credited with "incurable youth." The chief of these, delicate, insignificant, omnipresent in all gardens and most cultivated grounds, is the Chickweed, Stellària mèdia, which in October carpets the home of the early potato and of the kitchen-garden with a blanket of soft green, 


\section{S'TURDY SURVIVORS}

dotted with myriads of small, white, starry flowers. I have found it in bloom in northern Ohio thirteen months in succession, but that is a rare experience, for though it may be found in early January, the proverbial cold of the lengthening days of February usually destroys it. Others of the list are Red Clover, Self-heal, Dead-Nettle, Shepherd's-Purse, Pepper-grass, the Sow-Thistles, and the Dandelion. The last two are usually the latest to succumb.

The Sow-Thistles have marvellous vitality. Often in November a single plant, either a seedling or a sprout from a dying root, looks as green, bright, and hopeful as in midsummer; finally, when every flower is gone the erect stem holds up an adorable cluster of tawny pompons, capable of withstanding the storms of winter itself. The Dandelion, which possesses one of the most beautiful flowers ever vouchsafed to an ungrateful world, lives long, struggles bravely against principalities and powers, but at last succumbs. When I search the lawns and fields 


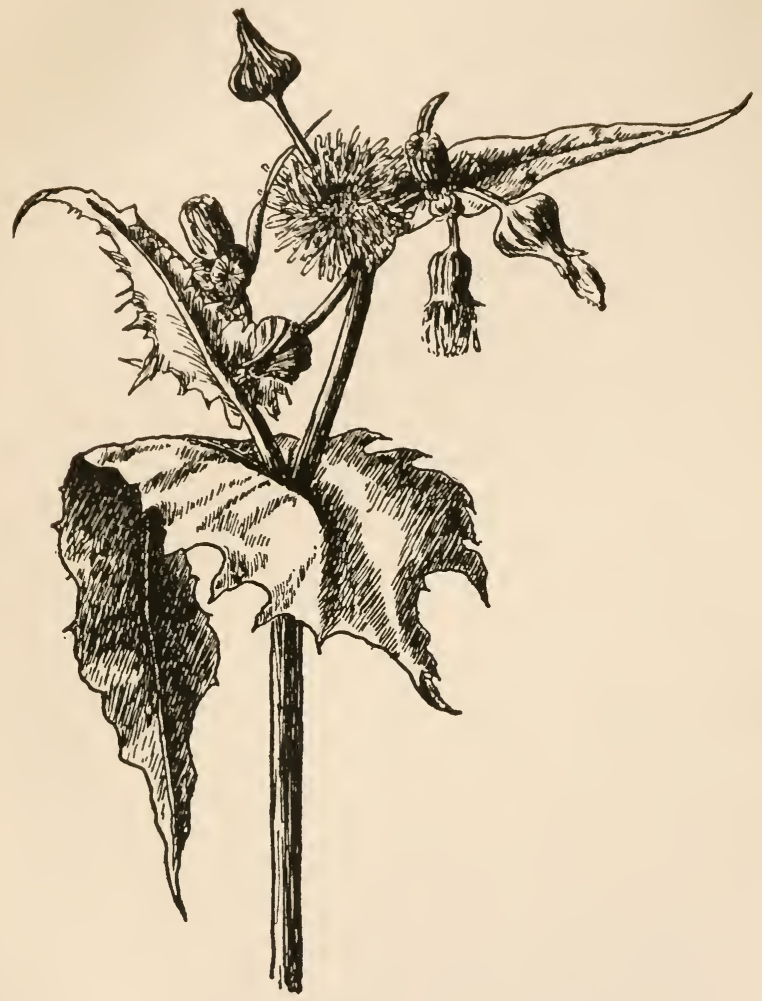

Common Sow-Thistle. Sonchus oleracens 


\section{STURDY SURVIVORS}

and no longer find my Dandelion smiling amid her morning tears, I know that the curtain has fallen, the lights are out, and the drama of the floral year is ended. 


\section{AUTUMNAL FOLIAGE}

\section{THE LIFE OF THE LEAF}

In order to understand the world-wide phenomenon of autumnal foliage it is necessary to think of each individual leaf as an active working unit, living its life and doing its work, apart from and independent of its thousands of companions. In spring when the buds swell and the awakened protoplasm begins to stream through the new growth, each leaf's work begins, and its work is a very definite task. This task simply stated is to hold its protoplasm in such relations to light, air, warmth, and moisture that chlorophyll can be produced. When this is done the leaf is green. The structure of the leaf, its thin body, its broad flat surface fits it to do this work. Through every leaf there runs a woody network which divides and subdivides throughout its structure, which supports its softer tissues and gives the leaf its shape and 
strength. Moreover, it serves the leaf as veins and arteries serve the human body, for sap creeps through these woody tissues in slow but con-

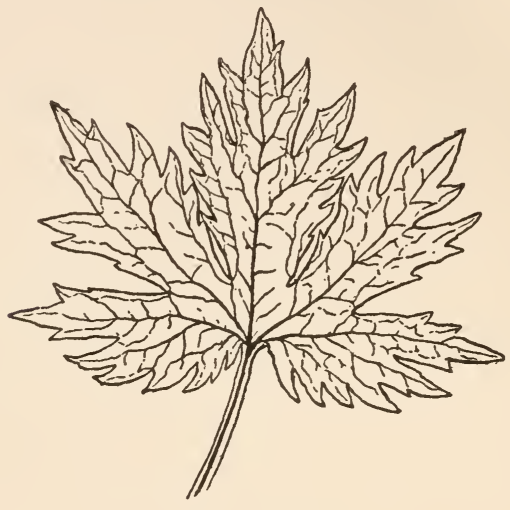

Leaf Venation

tinuous circulation. All these leaf veins are connected through the petiole or leaf-stem, with long lines of cells and tubes in the tree body leading up from the root and down again.

Leaves are supplied with breathing-pores called stomata, through which air and vapor can pass freely. These are connected with 
minute passages lying among the green cells of the leaf, and seem to be fairly automatic in their action; when there is too much moisture in the air they become gorged and close, if too little they dry and open so as to get all there is.

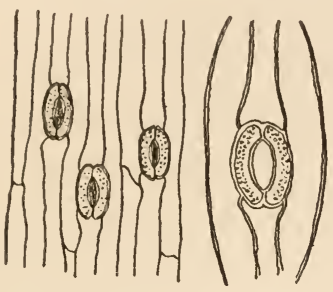

Stomata, Closed and Open

These stomata are easily seen under a microscope, are irregularly placed, and their number is simply enormous. For example, scientists report that in an apple leaf there are about I 58,670 in each square inch of the lower surface, moreover, they say that apple leaves are under rather than over supplied. When we consider what the leaf does we shall understand the need of these millions of breathing vents for the 
escape of vapor and the absorption of carbonicacid gas.

This entire arrangement is for the express purpose of making chlorophyll, and one wonders why all nature is so intent upon making chlorophyll. All summer long the world is covered with plants all making chlorophyll as hard as ever they can. Why? When we understand the reason all is clear, for if the plant world stopped making chlorophyll, the animal world would die. For chlorophyll is the great transforming agent of the world. It possesses the unique power of laying hold of the mineral and earthy elements of inorganic nature and transforming these into animal food. It has the power of breaking up carbon dioxide, what is popularly known as carbonic-acid gas, the product of animal breathing as well as of the combustion of carbonaceous matter; and under the influence of sunshine, and in the presence of water, of making starch, grape-sugar, as well as other carbohydrates.

A chlorophyll body is a little disk of dense 


\section{THE LIFE OF THE LEAF}

green jelly embedded in protoplasm, which under a microscope is seen to be full of holes; sometimes these holes are found filled with starch, which may be transformed into grape-

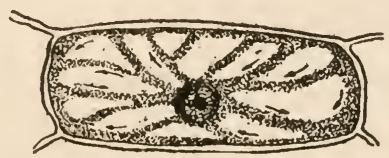

Cell showing Nucleus and Protoplasm. Greatly Enlarged. After Atkinson.

sugar, and passed on and down into the tree, feeding the cells and promoting the growth of the tree body, or going on to produce the fruit of the tree, or forming in combination other products such as cellulose, oils, and gums.

There are four essential conditions to the successful productive activity of the leaf. Sunshine must fall upon it, carbonic-acid gas must be in the surrounding air, so that it can be absorbed through the stomata, water must be supplied from the roots in continuous and unfailing flow, and the temperature must not be too low. Under these conditions the leaf sways with the wind, dances 


\section{AUTUMNAL FOLIAGE}

in the sunlight, and does its bit for the tree and the world.

The working life of a leaf in our climate is about four months, farther north it is shorter. All this time the leaf laboratory is at work, receiving from the root a continuous stream of water, absorbing from the air an unending supply of carbon, and by means of the sun's energy transforming these into food. Midsummer marks the height of its activities.

All summer long there has been this continuous intake of water, laden more or less with earthy or mineral substances; what has not been used has been released as vapor, leaving behind these earthy particles to clog the cells and consequently to lessen the leaf's power to work. In course of time more has been stored than the leaf knows what to do with, and often the accumulation appears as minute crystals in the cells of both leaf and petiole. From this point on the end is inevitable.

All summer long the intake and the outgo of the leaf laboratory have been fairly balanced 
but as August comes on this balance is disturbed. Doubtless there are subtile reasons for this that we do not know-but the cell space is clogged with foreign matter, the sunshine is less intense and, moreover, winter in which no leaf can work, is on its way. At any rate the fact remains.

And now the tragedy of the leaf begins in that the demand for output apparently does not lessen, while the intake not only lessens but finally stops. Under stress of this demand how enforced we do not know, the leaf gives up its working protoplasm, the chlorophyll bodies disintegrate and surrender not only all their products but everything of their composition which is valuable. The leaf is absolutely drained as time goes on of everything that is worth saving for the tree, and at last falls a hollow shell.

While the leaf is thus rending itself asunder it seems to be doing this to the very music of the spheres expressed in color, for this is the period of the great change. As the chlorophyll bodies disintegrate the green color changes into 


\section{AUTUMNAL FOLIAGE}

yellow. The scientists tell us that the green was always a compound of blue and yellow, and that somehow at this time the blue gets away and leaves the yellow behind, and that dying chlorophyll is always yellow. When this color is modified by the dying woody tissue of the cell walls, which is brown, it becomes russet. The color of dying chlorophyll, varied by many causes of which we have imperfect knowledge, ranges along the chord of yellow from the pale tints of the Birches and Silver Maples to the brilliant glow of the Tulip-Tree and the Poplar, the deep orange of the Sycamore, and the golden browns of the Oaks.

The autumnal reds are a different problem. It is known that the red is a liquid dye which stains the cell walls, but exactly why it comes or how it comes is not so well understood. It is a result of a lowered vitality and is believed to be due to acidity of the juices. Red leaves can be found here and there at any time during the summer. The baby leaf just coming from the bud in many cases is red; moreover, we have 
the continued presence of the Red Maples of Japan in garden and lawn.

The last act in the life drama of the leaf is the cutting off of the stem. In August a thin plate of cork cells begins to form at the point where the petiole joins the branch; this seems to be a device to protect the tree from bleeding when the leaf falls. Just outside of this cork layer there forms a band of rounded cells lying loose together with many empty spaces among them. This is the abscissa or "cutting off" layer; in some plants it shows as a pale ring encircling the petiole. By October everything is ready - the valuable products of the leaf have been withdrawn, the tree body is protected by a layer of cork, the petiole is cut off and clings only by a thread, so that when the winds beat or the rain falls, the leaf parts company from the tree and sinks quietly to its rest.

In the light of this life story we comprehend that the leaves are not slain by the frost, that their death is a biological necessity, and that their autumn colors are due to mechanical and 


\section{AUTUMNAL FOLIAGE}

chemical changes. They die that the tree may live, and their swan song appeals to the eye, not to the ear.

\section{THE COLOR CHANGE}

It is interesting to know just what investigators say about the color changes of autumn leaves, and the following from an article, entitled "Autumnal Changes in Leaves," by Justus W. Folsom, published in Garden and Forest, vol. VIII, is most illuminating.

"A green leaf or an alcoholic extract of one viewed through the spectroscope, shows a band of light or spectrum which is very characteristic; its dark intervals or absorption bands resembling those of no other substance. If now we mix benzine with our green solution of chlorophyll, which we have obtained by soaking say Elm leaves in alcohol, the liquid separates into two layers, the upper bluish green benzine, and the lower of yellow alcohol. These two solutions give different spectra, proving them to be differ- 


\section{THE COLOR CHANGE}

ent substances. Our chlorophyll, then, was a mixture of at least two substances, or more likely a chemical compound which broke into two of its constituent compounds, the yellow one being called xanthophyll.

"This separation presumably occurs when green leaves turn yellow as is suggested by this simple experiment. If our alcoholic extraction from Elm leaves has not been kept in darkness, and sealed from the oxygen of the air, it has rapidly decomposed, turning from green to yellow-that is, the green constituent fades away first, gradually revealing the yellow one."

The Seventh Report of the Forest, Fish, and Game Commission of the State of New York notes that Alfred Russel Wallace, an English scientist, states that chlorophyll is not a simple green substance, but that it really consists of at least seven distinct substances, varying in color from blue to yellow and orange, and that these differ in their proportions in the chlorophyll of different plants. Moreover, they have different chemical reactions, are differently af- 
fected by light, and each gives a distinct spectrum. He suggests the collective name chromophyll as a proper one for designating the presence of these various pigments.

A study of the "Autumnal Changes in Maple Leaves," by W. K. Martin and S. B. Thomas, published in the Botanical Gazette for April, I887, is instructive and illuminating. They write as follows: "Chlorophyll manufactured constantly under the influence of light is constantly undergoing decomposition by the metabolism of the cell. Under ordinary conditions, the manufacture of chlorophyll is sufficient to cover up its decomposition and the leaf retains its green color. Under changed conditions, however, such as intense light or decreased vitality, the decomposition of chlorophyll exceeds its manufacture and xanthophyll, probably one of the products of decomposition, appears. The condition of intense sunlight gives us the occasional summer yellowness, while to lowered vitality must be attributed the failure of chlorophyll manufacture in the autumn. This lower 
vitality is brought about by diminution of light, lowering of temperature, and probable causes in the plant itself.

"The red coloration is brought about in a very different way, as erythrophyll, or red dye, is manufactured in the leaf, and stains the cell sap, leaving the chlorophyll masses untouched. This red coloring matter cannot be discovered in any of the crude materials brought into the plant or in any other part of the leaf, except rarely in the petiole. When the leaf is ready to fall and the chlorophyll bodies die the erythrophyll lays hold of the cell wall and solid contents and stains them. In this way dried leaves retain their red color. As erythrophyll is soluble in water, contact with moisture will soon cause the most of it to disappear."

\section{ORDER OF COLOR CHANGE}

This grouping of trees in the order of coloration is that given in the Seventh Report of the Forest, Fish, and Game Commission of the State 
of New York. This order may vary somewhat in different sections of the country, but gives a good general basis for one's local observation.

\section{Group One-The Earliest}

Red Maple

White Elm

Sumach

Yellow Locust

Sour-Gum

Horse-Chestnut

White Maple
Yellow Birch

Hickories

Tulip Tree

Sassafras

Butternut

Black Walnut

Cucumber Tree

Group Two-The Intermediate

Sugar-Maple

Sweet-Gum

Chestnut

Yellow Wood

Red Oak

Pin-Oak

Black Oak

Beech
White Birch

Black Birch

Aspens

White Ash

Hop Hornbeam

Blue Beech

Carolina Poplar

Basswood

\section{Group Three-The Latest}

Scarlet Oak

Dogwood

Honey Locust

Lombardy Poplar
Sycamore Maple

Norway Maple

Ailanthus

Ginkgo 
White Oak

Larch

Black Cherry

Sycamore
Willows

Peaches

Apples

Pears

\section{PREVAILING COLORS OF AUTUMN LEAVES}

To describe satisfactorily the colors of our autumn leaves is an almost impossible task. So much of that color which impresses the beholder is made up of sunlight, so varied and so broken are the hues, so different in sunshine and in shadow, that it has seemed best to gather the descriptions of many writers, hoping that in the multitude of observations a correct impression may be conveyed. It would be quite futile to attempt to arrange or describe these colors according to the nomenclature of any school. For convenience the list has been arranged in alphabetical order. Dashes separate the descriptions of different writers:

Ashes, Fraxinus.-White Ash: The colors of this Ash are unique and distinguished from all other trees. Under favorable circumstances the coloring process 
is nearly uniform. It begins with a general empurpling of the whole mass of foliage nearly at the same time. There is an invariable succession of tints: First, the dark purplish bronze, then a chocolate-brown, and lastly a reddish yellow or simply a dull yellow, and then the leaves are ready to drop. The gradation of autumn tints are from darker to lighter hues.-Young trees usually color first, and their leaves are frequently a deeper purple than those of other trees.

Blue Asn: Purple and brown to yellow.

Red Ash: Rusty brown fading into yellow.

Beech, Fagus.-Clear golden yellow, becoming brown on young trees, and often clinging to the branches all winter.

Birches, Betula.-All the Birches turn yellow.-Pale dull yellow.

Black Haw, Viburnum.-Leaves vary from scarlet to vinous red.

Black Walnut and Butternut, Juglans.-In autumn the leaves turn bright yellow and fall early.

Chestnut, Castanea.-Color varies from yellow to russet, often green when other trees have turned. -Bright clear yellow.

Dogwoods, Cornus. - All the Dogwoods turn a peculiar dark red, combined with yellow, which is a characteristic of the genus.

Elms, Ulnus.-White Elm.-Pure yellow, lemon-yellow, brownish yellow. Browned with dying cellulose, 


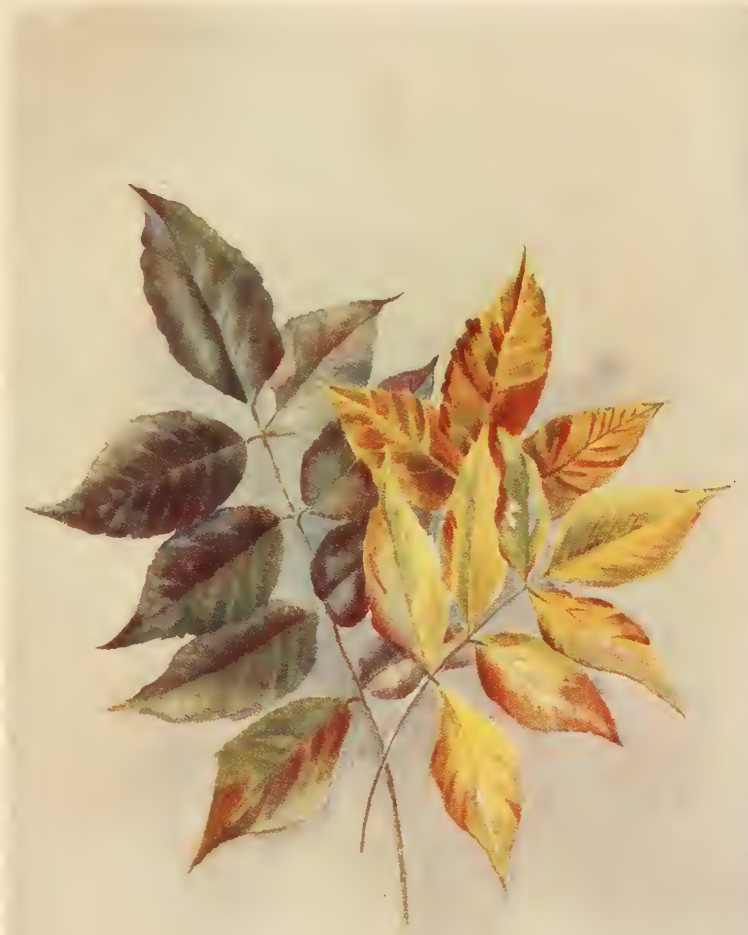

White Ish Leaves 



\section{PREVAILING COLORS}

rarely an even yellow. Rusty green and yellow. Orange with patches of yellow.

Cork-Elm: Bright clear yellow.

Slippery Elm: Dull yellow.

Fringe Tree, Chionanthus.-Orange and yellow.

Hercules Club, Aralia.-Bronze-red touched with yellow. Conspicuous, very beautiful.

Hickorys, Hicoria.-All the hickories turn a yellow more or less russet with dead and dying cellulose. - Tall hickories clad in the golden tans of autumn, dropping nuts and husks upon the ground beneath. - Clear to rusty yellow.

Hop Hornbeam, Ostrya.-Clear yellow.

Hornbeam, Blue Beech, Carpinus.-Combination of bright red, deep scarlet, and orange.

Horse-Chestnut, Esculus.-Leaves dull yellow, often shrivel brown, sometimes fall with little change of color.

Linden, Basswood, Tilia.-Clear pale yellow.

Liquidamber, Sweet-Gum, Liquidamber. - The autumnal coloring is not simply a flame, it is a conflagration; in reds and yellows it equals the Maples, and in addition it has the dark purples and smoky browns of the Ash.

Maples, Acer.-Red Maple: Young trees in swamps usually color first. Intense scarlet, scarlet deepening into crimson.-Burning bushes.-Single branch often turns a brilliant red when rest of tree is green.-Rarely yellow, sometimes crimson 


\section{AUTUMNAL FOLIAGE}

spotted on a yellow ground.-Its virtues not its sins are as scarlet.-A glory of color comes to the leaves of the Red Maple, for they illumine the countryside with their scarlet hue.

Sugar-Maple: The coloring glows in red which deepens into crimson, it flames in yellow that darkens into orange. These wonderful leaves will show colors as pure as any on the finest porcelain; a bright green leaf will show a single spot of crimson; a dark red shows a single lobe of rose-pink; the next will have a patchwork of yellow and scarlet like a palette set for a sunset picture.Yellow and red together with all the variations possible through the mingling of these with one another and with sunlight.-Deep red on onehalf the tree, the other half green, often entire tree a mass of rich yellow with a deep scarlet blush.

White Maple: Usually yellow, rarely showing a little red, the yellow usually pale. Rarely bears the vivid red leaf of either the Sugar or the Red.

Oaks, Quercus.-Vary upon the chord of brown: redbrown, gold-brown, bronze-brown, amber-brown. -Predominance of what we call leather colors with a considerable mixture of certain shades of red that are peculiar to the Oaks. We rarely find pure yellow or pure scarlet in the foliage of any species of Oak. -Oaks are more tenacious of their leaves than any other of our native trees except the Beech. 
Scarlet Oak: The especial glory of the species lies in the brilliant color which the leaves assume late in autumn. The autumnal tints of other Oaks are beautiful, but they pale their fires before the ruddy gleam of the Scarlet.-When the afternoon sun shines through the head the leaves glow with the rich red of a ruby.

Black Oak: In autumn the leaves turn brown, or dull red, or yellow and brown, and fall late, sometimes remaining until spring.-In autumn their tint is usually brownish yellow, rarely running into red, but even then the brown leaves shine as in midsummer, and dance in the November sunlight as if it were May.

Pin-Oak: Leaves turn a deep scarlet and fall late.

Chestnut Oak: Dull yellow, soon changing into a yellow-brown.

White Oak: In late autumn the leaves turn a deep red and drop, or on young trees remain on the branches throughout the winter.-The autumnal tints of the White Oak are also beautiful; its rich purplish red glows in the forest long after the Maples and Sumachs have shed their leaves.Stand under a White Oak and look at the sun, dull, solid red changes into a fiery glow or rich wine color.

Overbur Oak: Dull yellow or yellowish brown. Pepperidge.-See Sour-Gum. 
Osage Orange, Toxylon.-A clear bright yellow. Persimmon, Diospyros.-Orange or scarlet, sometimes fall without change of color.

Poplars, Populus.-All the Poplars turn a clear bright chrome yellow.

Sassafras.-Red and yellow, often pure yellow.-Rusty yellow.-The glory of the autumn foliage of the Sassafras is like the glory of a sunset, all mingled with purple and red and gold.

Sourwood, Oxydendrum.-In autumn bright scarlet. Sumach, Rhus.-Scarlet and yellow.-The Sumach in the swamp begins to look like the burning bush on Horeb.

Sweet Viburnum, Viburnum.-Deep red, or red and orange.

Sweet-Gum. See Liquidamber.

Sycamore, Planus.-Leaves turn dull orange and wither before falling. - The petiole encloses the leaf bud. Tamarack, Larix.-Pale yellow.-The Tamarack casts a soft yellow veil, a yellow haze, over the face of the northern country where it dwells.

Tupelo, Sour-Gum, Nyssa.-Its autumnal coloring is superb, the foliage becomes one glowing mass of scarlet, sometimes dashed with orange. It is the most fiery and brilliant of all that brilliant group: the Maple, Dogwood, Sassafras, Liquidamber, and Tupelo. The tree has different names; in the South it is generally called Sour-Gum, in the Middle West, Pepperidge, and in New England it retains its pretty Indian name Tupelo. 


\section{PREVAILING COLORS}

Tulip Tree, Liriodendron.-Clear, vivid, chrome yellow. - Produces many leaves of pure, unstained, unbroken yellow, of thick texture and unique form. Willows, Salix.-All the willows turn yellow, or leaves fall without change. Develop their foliage early and keep it late.

Witch Hazel, Hamamelis,-Yellow with rusty spots. 


\section{OCTOBER DAYS}

By the 20th of September the leaves begin to fall; they come down slowly, softly, deliberately, turning over a few times on the way; none are missed from the trees yet the ground is strewn with them. You look up to say "the trees are still in summer greenness," but even as you speak you hear the low rustle about your feet. The Goldenrods begin to show signs of age, but the Asters are in their glorious prime.

By the first of October the general effect of the foliage is still green, though more or less touched with color. The Sumachs crowding along the roadway or climbing the hillside are suffused with red, the Elms have yellow leaves and bits of yellow spray here and there, but no tree is yet entirely yellow. The Birches are dropping yellow leaves, but the trees are green. 
Single Red Maples, here and there particularly young trees in swamps, are entirely colored, but the Sugar-Maples are still content to show a branch of glowing tints among their prevailing green.

The Ashes are here and there showing their unique purple-bronze, the Woodbine billows over the fences or climbs to the tree-tops, a combination of wondrous reds, but the Oaks are green, strong, virile, giving no sign of weakness, and the Willows are like summer. Nevertheless, to the observer the fact is clear that the leaves no longer have a vital function to perform, that their work is done, and what we are about to see is the grand shifting of the stage from active life to the sleep of winter.

At this point October becomes to many people a state of mind. Day by day the great transformation scene progresses, almost from hour to hour the world forsakes its green, and the surface of the earth begins to flash like a prism and gleam like an opal.

It is now that one surrenders oneself to the 
charm of the season. It is well to follow Chaucer's direction:

"Forthe, pilgrim, forthe, $\mathrm{O}$ best out of thy stall, Loke up on high, and thank thy God for all."

Gates of pearl and streets of gold pale their ineffectual fires before the glories that nature sets on every mountainside and along every country path. He who has eyes to see let him see the glory that surrounds and enfolds him. The wonder of it all! No leaf is too small, no plant too humble, to fail to respond to nature's call. We think the glory is above our heads, it is also beneath our feet.

The spectacular effect differs as one stands viewing a mountainside or looking from the level. On the mountainside yellow flames run here and there among the reds and greens, or there may be a marvellous riot of varied yellows mingled with bronzes and browns, making a flat picture. Looking from the level one sees the forest showing three zones of color, also varied, by no means monotonous. The upper 
made by the topmost limbs of the tall trees; the middle zone the smaller trees and high bushes, with the gray trunks in serried masses; and the lowest zone made by the fringe of bushes, the running vines, the grasses and the weeds to which the sere fields make color union.

The autumn world flames in yellow. This is to be expected, since dying chlorophyll is yellow, and red is, to a certain degree, an interference; the reds of the second zone are furnished by the larger shrubs that in the lanes, bypaths, and waterways are able to display their glowing hues. Speaking broadly, while yellow predominates among the trees, red prevails in the foliage of shrubs and bushes.

October days are days for long, leisurely drives, for roadside luncheons under spreading trees while the auto waits, for long walks seeking nothing, that goal of the saunterer, since every path leads to the holy land.

Inland water, a small lake or pond, has a peculiar fascination at this season, its still, quiet beauty, its surface clouded with the superb 


\section{OCTOBER DAYS}

fusion of orange and scarlet, of reds and browns and bronzes that surround it and are reflected in it. These are the days when the world is afloat in a haze of purple and gold. The conflagration of the woodlands gives a brilliancy to the landscape that summer has never known.

The great leaf fall comes some time between the 17 th and 27 th of October. Again and again one hopes against hope that the unexampled will happen and that the fall will be deferred until on All Saints' Day the leaves may pass, as it were, in a certain odor of sanctity. What a fact to remember and to treasure! But it never is deferred, or at least it never has been in my experience. Other latitudes doubtless have other dates. One of two causes apparently precipitates the catastrophe, and we fondly think if these things did not happen the leaves would stay. But they always happen. Either we have two or three warm, sultry days, which ripen every leaf to its fall, when they come down softly and gently, turning once or twice with stem as rudder, or a furious wind 


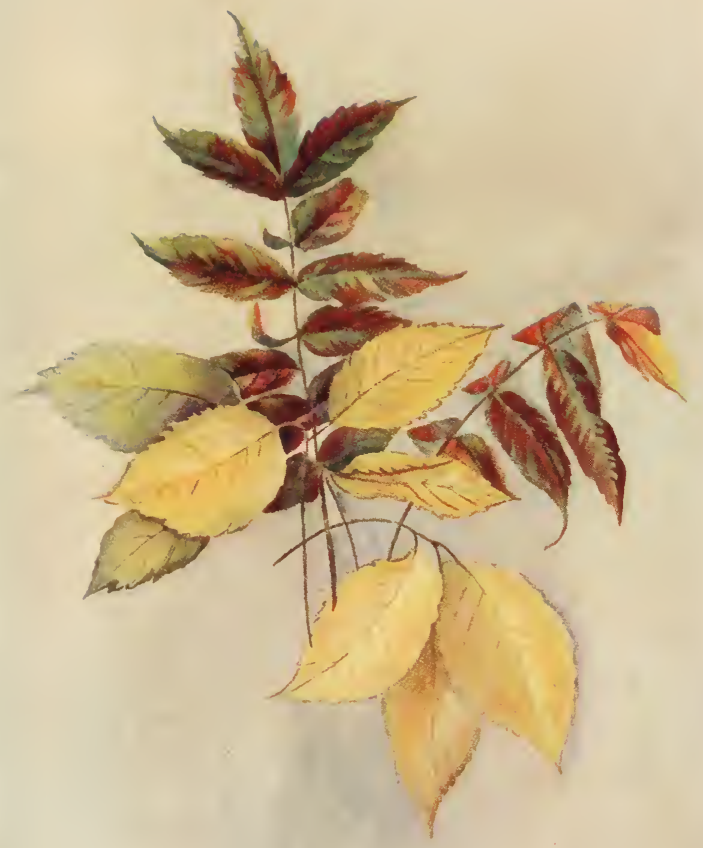

Staghorn Sumach and American Elm I.eaves 

and rain storm whips them, writhing and rustling, from the branch. When this storm comes early the losing struggle of the leaves is almost pathetic.

After the great leaf fall, nature seems to pause. There are warm bright days, the Oaks are virtually untouched, the Willows are green, and yet the fiat has gone forth, and for the rest they simply struggle with fate. Yet before the end the Oaks adorn the landscape with their sombre reds glorified by the sunlight, the Willows yellow, and Peach and Pear orchards show marvellous colorings quite beyond expectation. 


\section{THE KINDLY FRUITS OF THE EARTH}

As one wanders along the autumn paths one sees that the fruit is the concrete hope and expectation of the plant. One comprehends as the light seed, borne on its silver wing, sets sail toward the future, that all the life of the plant, all its strength of stem and branch, all the beauty and fragrance of the flower are but a means toward the accomplishment of one endto increase and multiply. Finally, when the embryo plant lies safely packed and stored in the seed, the winds of the air, the currents of water, the bird on the wing, the animal fourlegged or two, become the carriers, and as a result the wingless fly and the feetless run.

We think of autumn as the fruiting period of the year, as indeed it is, but midsummer also bears its argosies of grains and berries, and a few of our native trees and shrubs fruit in the springtime. The Elm, for example, casts its 
green samaras, its ripened fruit, upon the sidewalks of our cities even as the leaf buds begin to swell. The Mountain Elder fruits as the Common Elder is coming into bloom. But these exceptions do not change the general order of life that autumn is the great ripening and storing period of the vegetable world. Somehow the plant life of temperate regions has become aware of winter, and behaves as if it realized that what is to be done must be done quickly.

Now comes the struggle of the vegetable world to overcome its great handicap-the immobility of the plant. The parent organism is in revolt against this law and struggles continually to transgress and evade it, and either to invent or evoke legs or wings for its offspring. Thousands of seeds must be produced because so few survive, and quite incidentally, as it were, the animal world is fed. Nature works very efficiently by indirection and accomplishes one thing when apparently doing another. So the plant rooted to its place strives ever to send its seeds a-journeying. 
One Oak Tree casts a thousand acorns to the ground; unless these are planted away from the parent shade not one will survive to produce a tree. The hungry children of the wild note the feast; among them the squirrel not only satisfies his present needs, he looks to the future, and so day after day he diligently takes away acorns and buries them against his time of need. Some of these he recovers, others he forgets, and these forgotten ones in due time sprout and a few may achieve treehood. Of the year's crop a scanty half-dozen may transmit the line; in the meantime the hungry wildlings have been abundantly and generously fed.

A Dandelion lifts its fairy globe of seeds into the light and air. A passing bird seizing one sets others free, and the wind takes up a tiny brown seed poised on its silver wings and away it goes, careless and heedless, toward its destiny.

The berry offers its delicious pulp in return for a ride. The bird accepts and the seed dropped from its beak, or voided undigested, 


\section{THE KINDLY FRUITS OF THE EARTH}

finds a suitable home, the bird is fed and the tree or shrub is planted. And so it is that the fairest hedges are those sown by the winds and the birds - they are the fairies who plant the Wild Cherries, the Elders, the Blackberries, and the Wild Rose.

All fruits may be roughly divided into the dry and the pulpy, the bright colored and the dull. Most seeds that ripen in a capsule, that is a dry envelope, are exposed by the opening of the valves so that they may easily fall out and are readily taken by the birds. A wellknown example is the seed-vessel of the violet. Most seeds are rich in starch and many heavy with oil; for example, the oil content of Cottonseed and Flaxseed is very great. Of seeds embedded in pulp the books make several distinctions such as berries, drupes, aggregate fruits, and the like, but to the bird or the squirrel, the mouse or the child the main point is-are they pleasant to the taste?

It is interesting to note in passing that man is the greatest seed-eater of the world. 


\section{THE KINDLY FRUITS OF THE EARTH}

Long before he had learned to write history he had learned to raise wheat, so that its origin and early culture are quite unknown to us.

The number of seeds produced by a single plant-such as Horseweed, Pepper-grass, Aster, Goldenrod, Mayweed-is almost unbelievable until one investigates.

For example, a single well-grown plant of Pepper-grass, Lepidium, produces from I,200 to 2,000 seeds. It is recorded that in one square metre of the surface soil of a fallow field, taking it to the depth of ten inches, there were 10,332 seeds having power to germinate, the number determined by three successive weedings. Darwin reared 80 seedlings from a single tiny clod on a bird's foot. When one watches a flock of sparrows feeding, apparently with satisfaction and contentment, upon what seems to be a barren waste, one needs only to recall the untold number of seeds scattered by the weeds we know, to estimate the enormous amount of food present upon the surface of the soil. Good food, 


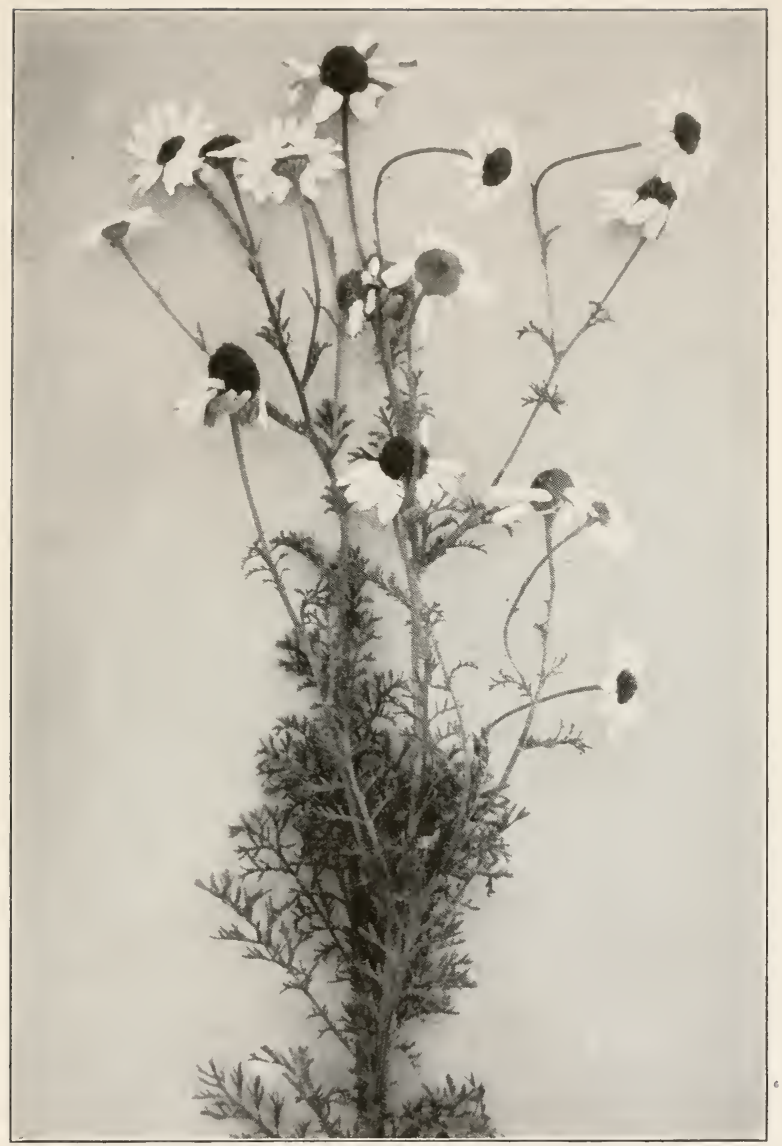

Mayweed. Ánthemis cótula 

heavy with starch and albumen and oil, supplied to the beasts of the field and the birds of the air, by the kindly fruits of the earth.

It is perhaps well to put clearly here the meaning of fruit as the botanist knows and uses it. Fruit to him means, first, the embryo of the plant with whatever may be provided of starch, albumen, or sugar to enable the first roots to sprout and the first leaves to form. This with a compact and closely fitting cover constitutes the seed. If there is nothing more, then the seed is the fruit. But very few seeds are left without an additional covering; in the apple it is the flesh, in the berry the pulp, in the capsule it is the strong, dry cover that protects the enclosed seeds. This seed-cover, whatever it may be, together with seed or seeds within, makes the fruit of the plant. As most rules have some exceptions, it may be noted here that the akene, which is a dry seed-cover protecting a single seed, is often called a seed; but whatever one calls it, one should know that it is really a complete fruit. 


\section{THE KINDLY FRUITS OF THE EARTH}

A transcribed conversation, perhaps, will make the matter clear.

"Then the seed is the baby plant, packed up and ready to travel, usually with its lunch basket along."

"Exactly."

"And the fruit is the whole thing, not only the seed, but whatever goes along with the complete ménage-the baby and the baby-carriage, as it were."

"Precisely."

"And whether this combination is of any value or interest to us, has nothing whatever to do with the fact that it is fruit."

"Nothing whatever-it is to be considered solely from the view-point of the plant." 


\section{DRY FRUITS TRANSPORTED BY THEIR OWN DEVICES}

Of the many seeds that sail or float, the ones best known are those of the Dandelion, the Thistles, and the Milkweeds; in addition are the Asters and the Goldenrods. All of these with one exception are Composites; the flowers in heads and the calyxes so compressed that the body of the calyx is grown fast to the ovary, and only the upper part is separate. This develops into a number of delicate hair-like bristles, white or tawny, which separate when the seeds are mature and ready to fall from the protecting involucre; the minute hairs spread out, and there is a sort of parachute formed of sufficient size and strength to bear the seed far afield. With the bristles perfect, the seed well weighted, and the wind not too strong, the airy journey may be of considerable length.

The structure of the fruit of the Milkweeds is different, though the result is the same. The 


\section{DRY FRUITS}

large, rough pods in late autumn are packed with flattened brown seeds which overlap each other like the shingles on a roof. As they lie in a carefully opened pod they make a most exquisite picture. Each seed has a tuft of long, silky hairs on the inner end, and in drying these bristle out, spread, and, caught by a passing breeze-away, away, and away they go, catch them who can. At last they drop, and the race is over.

The Wild Clematis of the fields clambering over fence and shrub provides its ripening seeds with travelling plumes. After the corollas fall and the ovaries are maturing the styles begin to grow, lengthen an inch or more, become hairy, and in place of the exquisite white flower clusters of midsummer appear the beautiful grayishwhite tufts of seeds which in time are whisked away by the wind, and each akene is given a spiral twist as its little white plume curls it away. Whenever a seed of any kind is found to possess a plumose attachment it means its distribution by the aid of the wind. 


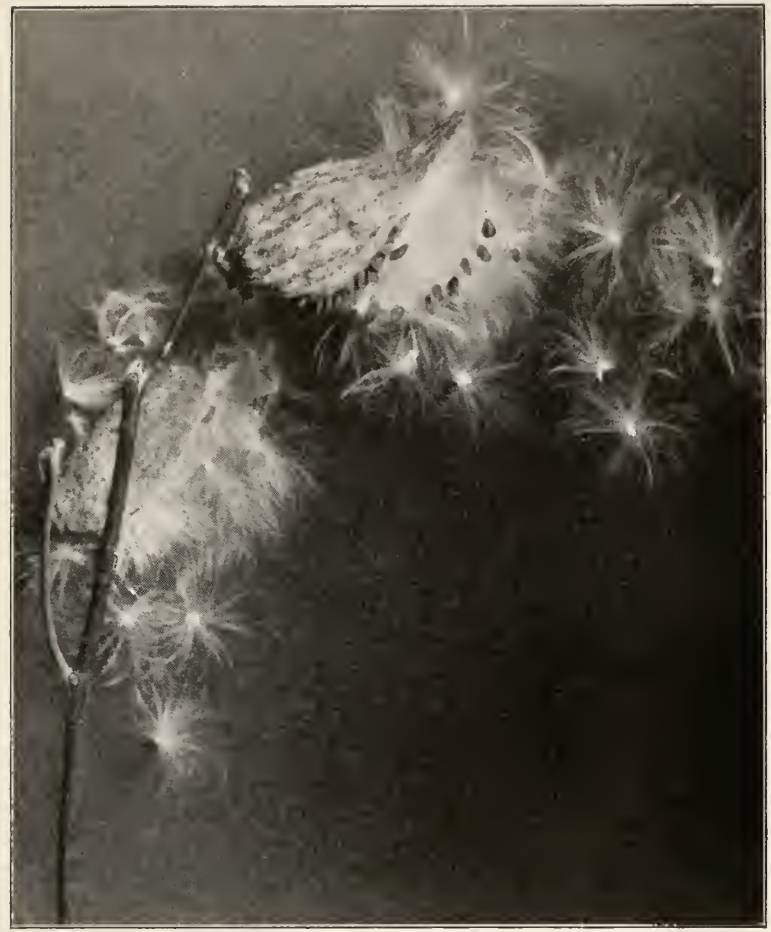

Milkweed Seeding Itself 

Another group of dry fruits possess membranous attachments of various forms whose use is to buoy them up, at least long enough to get away from the parent shade. Well known of these are the double keys of the Maple, the single keys of the Ashes, the samaras of the Elms and Birches, and the winged seeds of the Tulip Tree and the Catalpa. Whenever a seed is found on tree or herb, in a pod or capsule of any kind with a thin membranous attachment, it means that somehow the wind must carry it - a few feet or inches from the parent plant.

Among others are the Riders, a gallant group, that cling to their steeds through thick and thin, and are prepared to cope successfully with man or beast who comes their way. Two well-known families fittingly represent the whole: Bidens, known as Beggar-Ticks, Spanish Needles, having flat seeds armed with two or more barbed points; and Desmodium, or Tick-Trefoil, possessed of a clinging pod that breaks into pieces rather than let go its grip. With these are the Burdocks and Cockleburs-all efficient and all unpleasant. 


\section{DRY FRUITS}

Still others project their seeds from the parent stem. Many do this; perhaps the one best known is the Jewelweed, or Touch-Me-Not. When the capsule is sufficiently ripe a touch will upset the calm of the entire arrangement. I think no country child foregoes the pleasure of pinching the tiny fruit vessels in order to see the entire structure curl itself up under his fingers and the seeds shoot away, nor will he stop until the last tiny adventurer has been started on its life journey. What happens is that the jar sets the five valves of the seedcover free, they coil up suddenly and the small seeds are thrown several feet away. The woody pods of Witch Hazel contract unequally, the valves are suddenly spread apart and the seeds are hurled away. 


\section{FLESHY BUSH FRUITS}

Autumn is rich in the fleshy fruits that shrubs and vines offer to her wildlings. At the edge of northern woodlands, in pasturelands, along lanes and byways, wherever the sunlight can come in, the Blackberry and its companion, the Dewberry, take possession and of ten precedence. Both bear black, shining fruit of the aggregate type, made up of many little stone-fruits adhering to a white receptacle from which they refuse to be parted. Hybrids of both appear in our gardens.

Stony fields and rocky hillsides bear a crop of Blueberries and Huckleberries that is beyond computation; the fences are laden with the burden of Elderberries and Barberries; Cranberries creep over the bogs later, the Winterberries give a red glow to swamps and lowlands; at the north a carpet of Bearberries covers vast areas; and upon the forest floor an enchanting combination of Creeping Snowberries, Partridge- 


\section{FLESHY BUSH FRUITS}

berries, Wintergreens, and Bunchberries offers a feast to the hungry.

Choke-Cherries hang in drooping racemes from numberless bushes, and the little red apples of the Hawthorn are everywhere. These fleshy fruits, upon the whole, are either berries, pulpy fruits with several seeds, or drupes, pulpy fruit with a single stony pit, or little apples, called pomes. Their colors vary among red, black, purple, blue, and white.

\section{VARIED REDS}

Barberries, Berberis.-All species bright red.-The scarlet pennants which stream from the Barberry bushes.

Bittersweet, Celastris.-A climbing vine, the opening orange pods show the scarlet seeds.

Black Alder, Winterberry, Ilex.-Twigs loaded with red berries. The coral beads of the beautiful Black Alder.

Bunchberry, Cornus.-Abundant on the forest-floor. Brilliant shining red.

Choke-Cherries, Prumus.-Varied reds, very rarely

yellow. Currant-like clusters.

Coral-Berry, Symphorocarpus.-Dark red. 


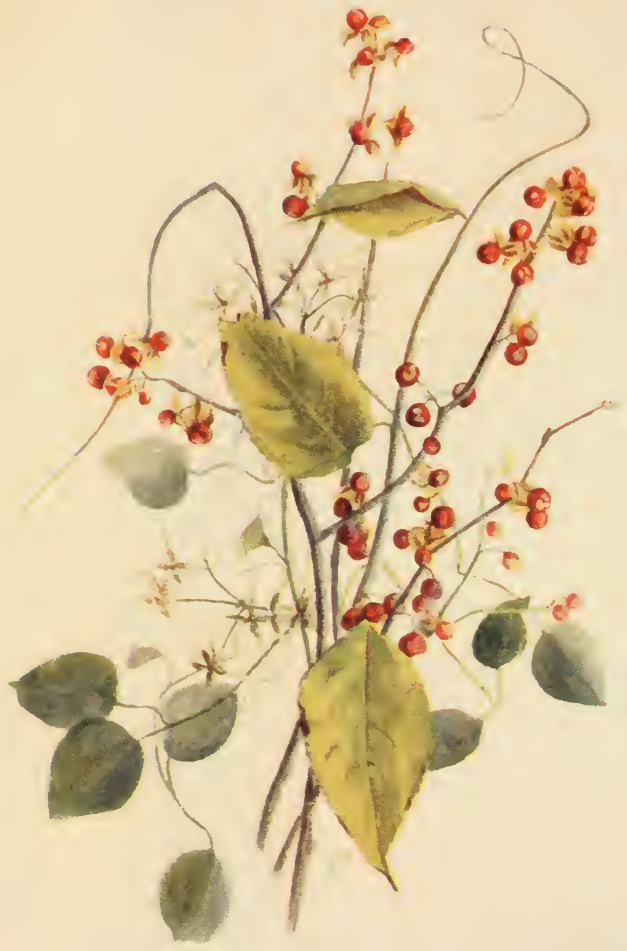

Bittersweet and Mild Clemat is 



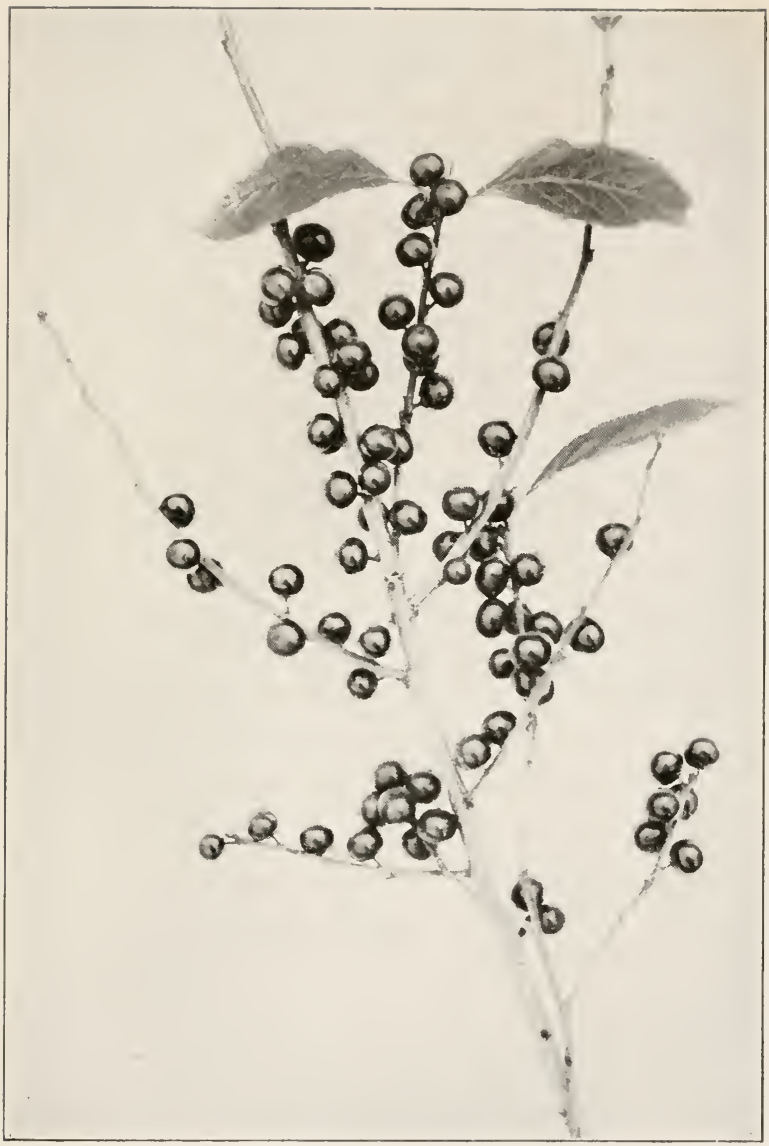

Smooth IVinterberry. Ilex lavigàta 

Cowberry, Vaccinium.-Dark red, acid and bitter. High elevations.

Cranberry, Oxycoccus.-Bright red. In bogs and swamps.

Flowering Dogwood, Cornus.-Bright red, clustered in the axils of leaves.

Harmless Sumachs, Rhus.-A hairy stone-fruit, acid, borne in terminal clusters, persistent as red spikes all winter.

Hawthorns, Cratagus.-Pomes, little apples, most of them dull scarlet.

High Bush Cranberry, Viburnum.-Bright red.

Hollies, Ilex.-Bright red.

Maple Leaved Arrowwood, Viburnum.-Crimson, turning purple-black.

Matrimony Vine, Lycium.-Orange-red.

Partridgeberry, Mitchella.-Bright red, a double berry. Red Bearberry, Arctostaphylos.-Deep red.

Red Chokeberry, Pyrus.- - Red varying to purple.

Red Raspberry, Rubus.-Aggregate fruit, translucent. Roses, Rosa.-Hips, varied reds.

Spicebush, Benzoin.--Red, stalk not thickened. Gleaming, translucent, red berries.

Winterberry, Ilex.-Two Winterberries glorify the swamps and cast a ruddy glow over the fields where they abide from leaf fall to midwinter. They are little bushes, one of them known as Black Alder, inconspicuous through all the summer days-but when October comes the Winterberry stands 


\section{FLESHY BUSH FRUITS}

clothed in scarlet, aflame to the utmost top of its tiniest twig.

Wintergreen, Gaultheria.-Bright red.

\section{VARIED BLUES AND PURPLES}

Alternate-Leaved Dogwood, Cornus.-Deep blue on reddish stalks.

Arrowwood, Viburnum dentatum.-Bright blue.

Blueberries, Vaccinium.-Blue with or without a bloom. Hobble-Bush, Viburnum.-Red, becoming purple.

Huckleberries, Gaylussacia.-Varied blues, nearly black.

Round-Leaved Dogwood, Cormus.-Pale blue.

Silky Cornel, Cornus.-Pale blue.

Virginia Creeper, Ampelopsis.-Dark blue, almost black.

Wild Grapes, Vitis.-Blue-purple, nearly black.

\section{WHITE}

Creeping Snowberry, Chiogenes.-In mountain woods the tiny evergreen leaves almost hide from view the spotless fruit.

Panicled Dogwood, Cornus.-Clear white.

Poison-Ivy, Rhus.-Dull white to lead color.

Poison Sumach, Rhus.-Dull white.

Red Osier Dogwood, Cornus.-Clear white, rarely lead color.

Snowberry, Symphoricarpus.-Brilliant white in clusters. 


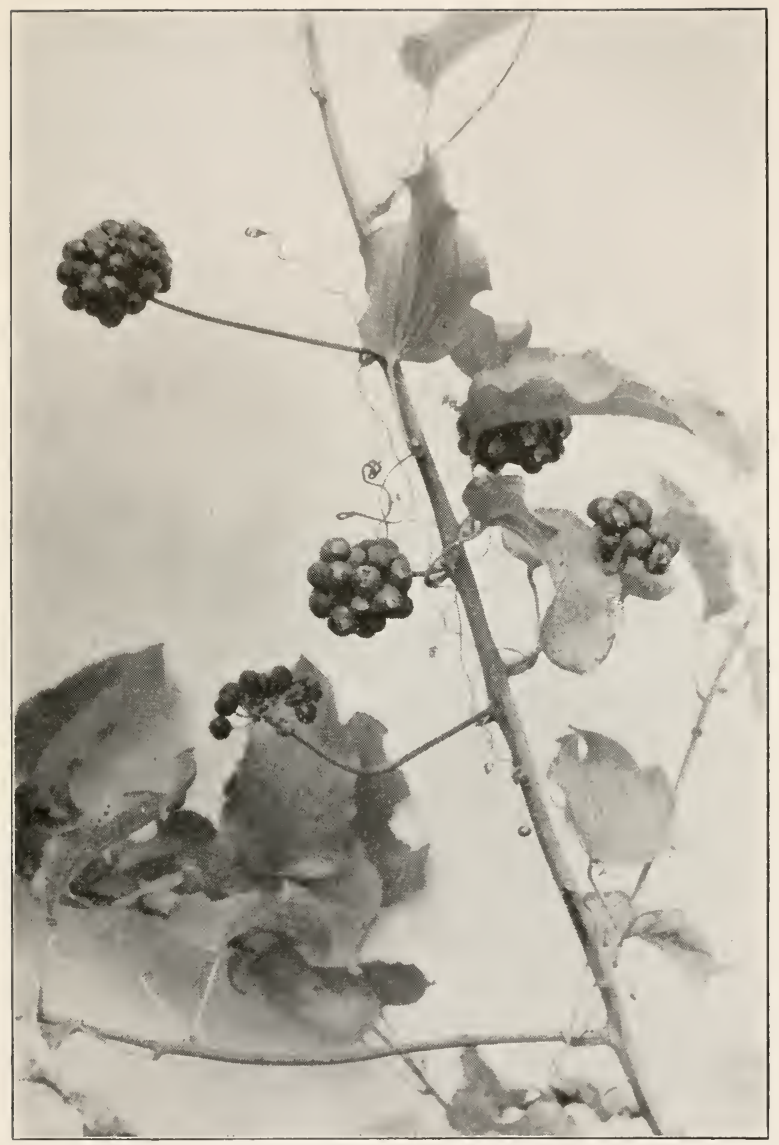

Greenbrier. Smilax herbicea 



\section{FLESHY BUSH FRUITS}

\section{BLACK, OR VERY DARK IN COLOR}

Blackberry, Rubus.-Shining black, aggregate fruit.

Black Chokeberry, Pyrus.

Black Raspberry, Rubus.-Dull black, aggregate fruit.

Dewberry, Rubus.-Shining black, aggregate fruit.

Downy Arrowwood, Viburnum.-Dark purple, almost

black.

Elder, Sambucus.-Black-purple.

Grapes, Vitis.-Black-purple, often with bloom.

Greenbriar, Smilax.-A thorny vine with black berries in clusters. One species thornless.

Hackberry, Sugarberry, Celtis.-Dark purple, almost black.

Maple-Leaved Arrowwood, Viburnum.-Nearly black. Sweet Viburnum, Nanny-Berry, Viburnum.-Bluish black, with a bloom.

Stag-Bush, Black Haw, Viburnum.-Bluish black, with a bloom. 


\section{HERBACEOUS PLANTS WITH CONSPICUOUS FRUITS}

A goodly number of herbs follow the example of trees and shrubs, pack their seeds in pulp, provide them with an attractive cover and so do all that is possible to lure the wings that shall bear them away from home. Red is a color seen from afar, hence it is not surprising that many fruits are red. There are other fruit colors, blues and purples, blacks and whites, but the red stands out showy and striking.

The following list is by no means complete but it includes many of those plants one ordinarily sees in autumn walks.

\section{VARIED REDS}

Disporum, Disporum.-One of the early flowering plants, so inconspicuous as to be almost unknown, produces single or in pairs, at the ends of branches, oblong, pointed berries of brilliant red. 


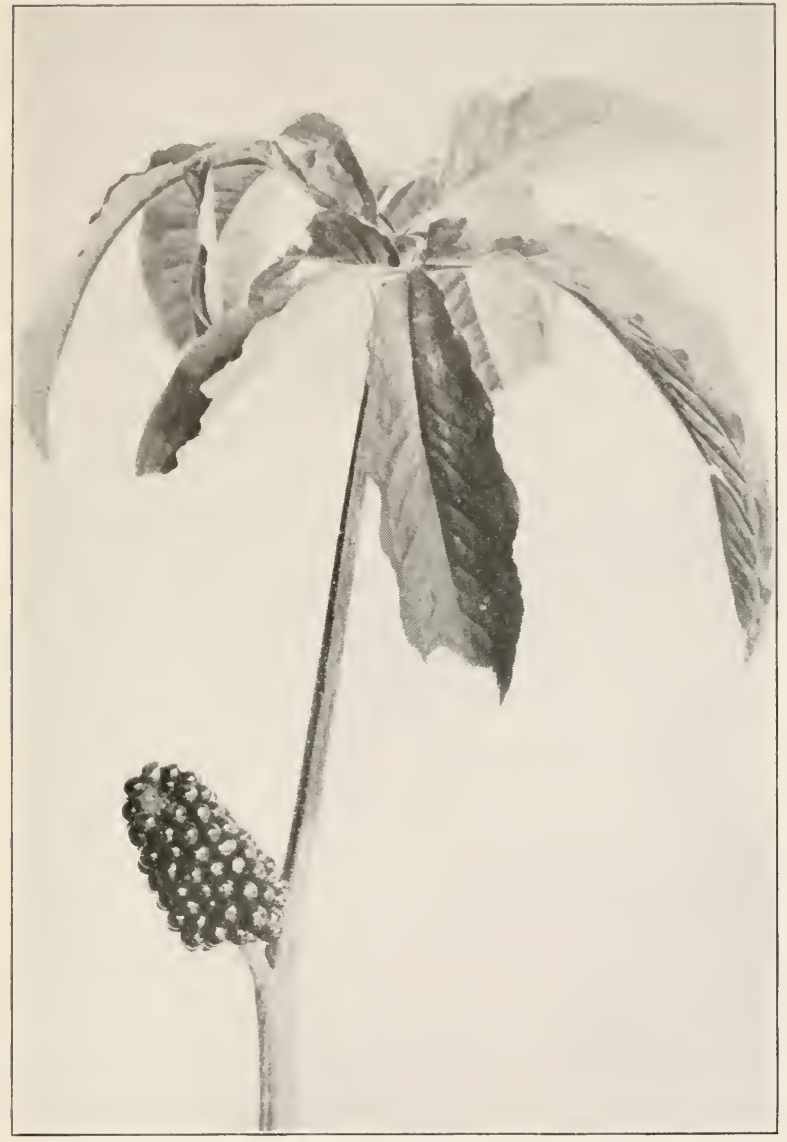

Jack-in-the Pulpit. Arisemma triphyllum 

False Solomon's-Seal, Vagncra.-Pale, translucent, and pearly, speckled with red; small, clustered at tips of stems.

Flower of May, Maianthemum.-Pale pearl, speckled with red; clustered in a lengthened raceme at summit of stem. Plant three to six inches high.

Ginseng, Panax.-Bright crimson, in umbels.

Jack-in-the-Pulpit, Arisama.-In September one comes upon a ball of brilliant scarlet berries, borne at the summit of a stiff drying stem, the contribution of Jack to the world. "There is nothing translucent in the glossy vermilion club-clusters of Jack-inthe-Pulpit. This plant that seemed so averse to color that it showed no more than green and brown in its vernal spathes, now fairly dazzles with its red richness."

Nightshade, Solanum.-Bright, shining scarlet.

Red Baneberry, Actaa.-Cherry-red, oval berries in a short terminal raceme.

Skunk Cabbage, Spathyema.-Globular mass at the base of stalk filled with large, red, shining balllike seeds.

Trilliums, Trillium.-All have rather large, ovate, many-seeded berries of dark red, borne at tips of stems.

Twisted Stalk, Streptopus.-Red oval berry on slender stem, in the axils of the leaves. 


\section{HERBACEOUS PLANTS}

\section{BLUE}

Blue Cohosh, Canlophyllum.-Naked seed of bright blue, the size of large peas and resembling drupes. Clintonia, Clintonia.-Northern in habitat, the berries on erect stems that rise above the large polished leaves of the plant. As they begin to ripen they turn a beautiful blue that darkens as they grow older.

Solomon's-Seal, Polygonatum.-Borne in pendant pairs along the curved leafy stems. Dark blue, nearly black, with a bloom.

\section{BLACK}

Blackberry Lily, Bclamcanda.-Black seeds borne on a central axis, suggesting a Blackberry.

Deadly Nightshade, Solanum.-A coarse annual weed. Pokeweed, Phytolacca.-At fruiting time the plant glows and throbs with color. It flames in crimson; stem, branches, branchlets, fruit stems and pedicels, petioles, midribs, and veinlets, all red, a glowing red. The final and compelling touch to all this gorgeous coloring is the raceme of black berries pendent from every stem and stemlet.

\section{WHITE}

White Baneberry, Actaa.- "There is just one brilliant white. This is the baneberry. Uniqueness would be disastrous, but for three or four safeguards. 


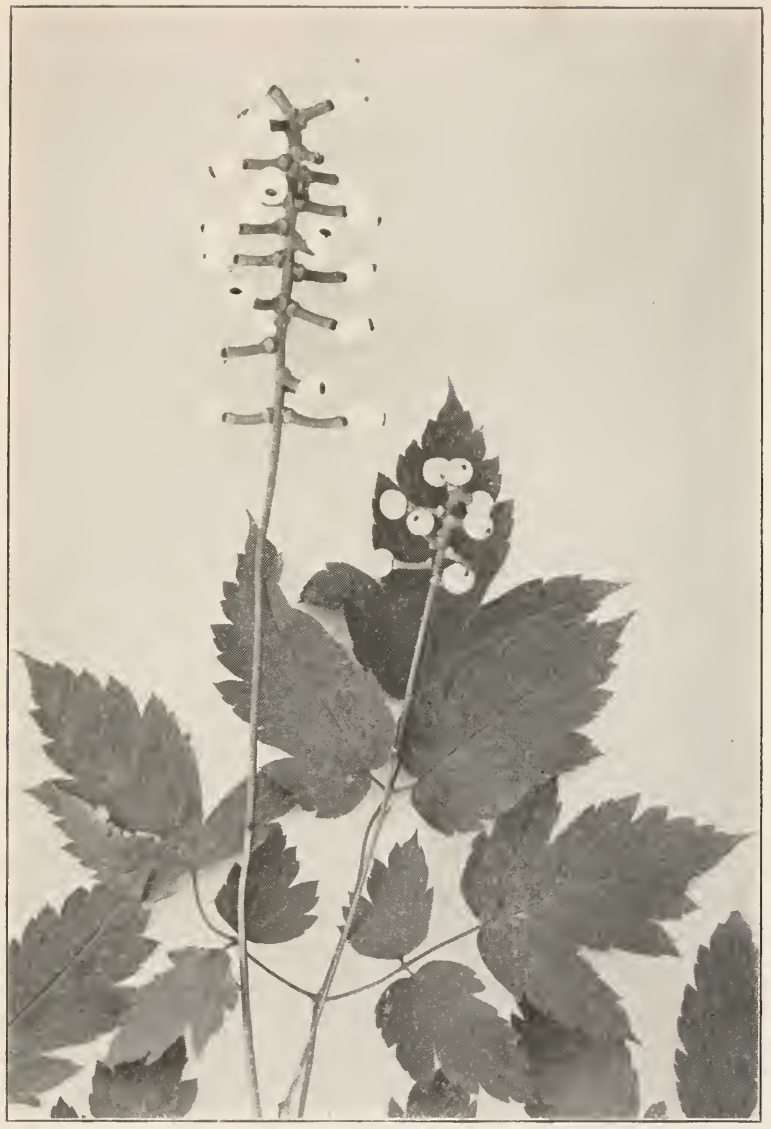

White Baneherry. Actìa álba 

The baneberry's beauty comes in the fall when most human woodfarers are not bent on picking posies. The baneberry's fruit is so sensitive that it is likely to fall before it can be brought to vase. And, best of all, it has the repute of being poisonous (hence the name), and for this reason it is seldom molested.

"Such a marvel of a fruit. It is as white as the whitest thing you know with a black dot on the end of it. Some one has aptly likened it to the china eyes of dolls. Yet its whiteness is not its only claim. Each whitest white berry is borne on a fat little stemlet of deep claret red. And so perhaps we may stretch a point and class this most arresting of woodland fruits among the predominating reds."-CARL T. ROBERTSON. 


\section{THE GULTIVATED FRUITS OF AUTUMN}

The most conspicuous of these are the Apple, Pear, Peach, and Plum, together with the Grape and Tomato; the Cherry, very near the Plum in structure, ripens in midsummer. Of these the Apple is by far the most beautiful and the most useful fruit. A healthy fruiting Appletree is a thing of beauty; the poise of a leafless tree is that of rugged, picturesque strength, braced and squared to bear its burden of fruit. One may apply to the Apple, with little change, the saying of Izaak Walton in respect to the Strawberry: "Doubtless God might have made a better fruit but doubtless God never did," and this in full knowledge of the delicious Orange, the wondrous Grape-Fruit, and the luscious Peach.

A cross-section shows clearly the structure of the Apple. A thin strong skin, a body of pulp, filling a clear space of several cubic inches, a 
core and seeds. The study of an Apple blossom will make the matter clear. The calyx is a hollow cup with five pointed lobes. Upon its edge within the circle of lobes sit the five petals of the corolla and twenty or more stamens. Within the cup are the five-celled ovary with its ovules, and the five styles and stigmas. As the fruit develops the calyx-cup enlarges, unites with the ovary, becomes fleshy, the inner part of the ovary changes into papery texture and forms the core, and the ovules develop into seeds, two in each division of the ovary. The calyx lobes remain at the summit of the fruit, and the stem is in a dimple at the base. The truit has captured and retained all of the flower except the petals and the stamens. Such a fruit the books call a pome. In such stone-fruits as the Plum and Cherry the calyx-cup is hollow, and the petals and stamens sit on its edge; but the ovary enlarges to form the fruit, and the cup withers. Grapes and Tomatoes are berries, a fruit in which the seeds are embedded in juicy pulp; the seeds themselves vary in character. 


\section{NUTS}

The common fruits known as Nuts are varied in character, but may be grouped as: Acorns, Hazelnut, Chestnut, and Beechnut, Hickory Nut, Walnut, and Butternut.

The acorn fruit is individual, composed of two very distinct parts, the acorn and the encircling cup at the base, in which the acorn sits. This cup is a curious and beautiful structure, supposed to be a development of the involucre. When the acorn is ripe the nut shrinks a little and falls out of the cup; sometimes it falls with the cup. The acorn figures largely as food for the wildlings. In England long ago it was highly prized as food for swine, and in the Doomsday Book woods were valued according to the number of swine they could feed. In the case of Hazelnut, Chestnut, and Beechnut the involucre at the base of the flower enlarges, grows around the nut and completely envelops it, forming the husk or burr. When the fruit is ripe, in the case of the Chestnut and Beechnut, the burr opens and the nut falls out. 


\section{CULTIVATED FRUITS}

In the Hickory Nut the "shuck" probably consists partly of calyx and partly of consolidated bracts of involucre; when the fruit is ripe it opens and releases the nut. In the Walnut and Butternut the "hull" is probably of the same origin as the "shuck" of the Hickory, but it does not split open as it ripens. It remains fleshy, and the nut is usually removed by drying the cover. It has been discovered that the charcoal made by burning the shells of nuts, as well as the pits of stone-fruits, makes the best absorbent of poisonous gases yet known. 


\section{NOVEMBER}

"November woods are bare and still, November days are clear and bright;

Each noon burns up the morning's chill The morning's snow is gone by night.

Each day my steps grow slow, grow light As through the woods I reverent creep Watching all things lie down to sleep.

And half I smile and half I weep Listening while they lie down to sleep."

- Helen Hunt Jacrson.

The leafless tree is the first sign manual of November. One awakens from the dream of October splendor dazed a little by the sudden crash with which all its glories fell to earth. By and by the compensations come in, and the silhouettes of trees softly etched against the horizon line bring their own message of beauty. The fields are sere, each day shows more ravages of storm and frost, the dull days depress the spirit, and almost in bitterness we are ready to say with Hood: 
"No sun-no moon-no morn-no noon,

No shade-no shine-no butterflies-no bees,

No fruits-no flowers-no leaves-no birds,

November."

But if one is willing to accept and enjoy a different world it is to be had for the asking, for now, when the trees stand bare, the secrets of the forest are revealed. The tall slender young Oaks, the sturdy outstanding old ones, the dignified Hickories, the homelike Sugar-Maples, the beautiful gray Beeches, the graceful Elms stand in brotherhood with interlacing branches, and between and among them sunlit spaces open and stretch away all unknown before. The joy of knowing these naked trees is very great. The Elm is never rugged like the Oak; its poise is full of grace and graciousness, and the free swing of the wide-spreading branches upon opposite sides of a roadway inevitably suggests the pointed Gothic arch in simplicity and obvious strength.

The persistent russet and red leaves of the Oaks are long in pleasant evidence; finally to 


\section{NOVEMBER}

one complexion they all come, a fine, rich brown, of ten with a bluish-red flush beneath, a color they do not lose on the tree or on the ground. It is especially pleasant to walk among these fresh Oak leaves, so exquisite their shape, so fine their texture, so compelling the charm of their golden brown, so loose they lie, at easea poise they will not lose; though the snows of winter cover them deep the bright days of spring will find them beautiful and unchanged.

November throbs with color, in low tones it is true, but with a depth that tears one's heartstrings. The yellow-browns and dull reds of soil and stubble, the pale yellows of meadow and pasture, the last flicker of dying chlorophyll merge into purple shadows, in which all unite, and so united the wave of color surges up and about the gray trunks and varied tops of the surrounding woodland.

Drive with a seeing eye through and by the deserted fields and the mystery of these enchanted distances reveals itself. A wood of Maples and Beeches becomes a deep blue-purple. 


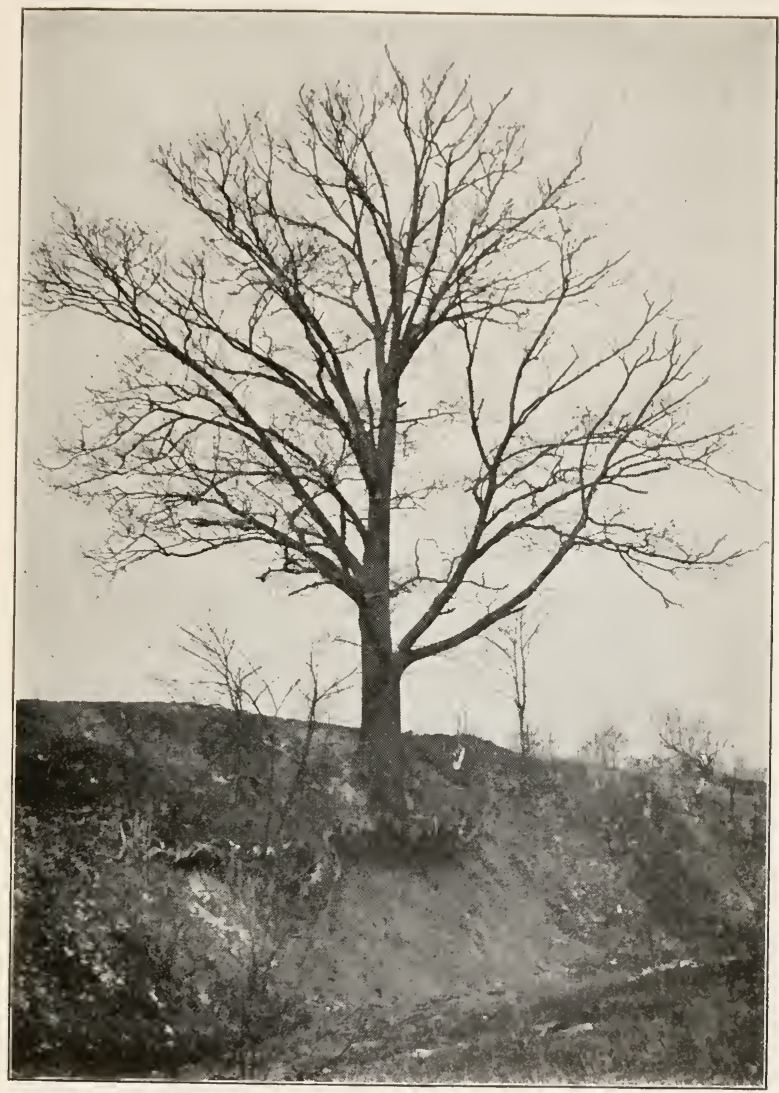

Elum. Ílmus Americina

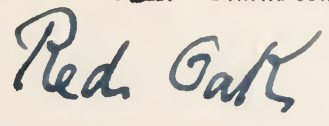



In other woodlands where are many Oaks with persistent leaves, perchance some Sumacs, a distinct reddish tint flushes the purple. In a varied wood, dark gray, steel gray, purple and reddish tints coalesce into one mass of deep, subdued color, always purple, ever darkening in to darkness.

This is for dull, cloudy days, but when the sun breaks out, or the slanting rays of sunset enter the wood and seek out the inner shrines of the temple, the half-gods go, for the true deities have come to their own.

A feature of these November days as the month wears on is the silence that gathers in field and wood. The birds have gone. The insect life that was so shrill and insistent in midsummer has lessened, day by day, into a silence rarely broken by the buzz of a bee, the lonely chirp of a cricket, or the chatter of a blue jay. To insect life the night of Brahma has already come, and all its life has retired to the egg, to be summoned forth only by the energy of the sun. The same thing is true of annual plants: 
their life lies dormant in the seed. This is exquisitely told by Edith Thomas:

"'You think I am dead', a soft voice said,

'Because neither root nor branch I own;

I never have died, but close I hide

In a plumy seed that the wind has sown.

Patient I wait through the long winter hours,

You will see me again,

I shall laugh at you then,

Out of the eyes of a hundred flowers."”

It is astounding, as one thinks of it, how life, all life, passes over the "molecular bridge," not simply in ages past, but now, to-day.

The trees frankly hibernate; they have cast their leaves, have packed their juices, have protected their growing buds against harm, and are ready waiting for the time when the sun turns north and spring is again upon its way.

November is the month of Indian summer, if, indeed, we still have an Indian summer. Certainly, there come in November soft warm days, after the first cool weather of October, days of blue haze and mellow light and warm air, when I 80 


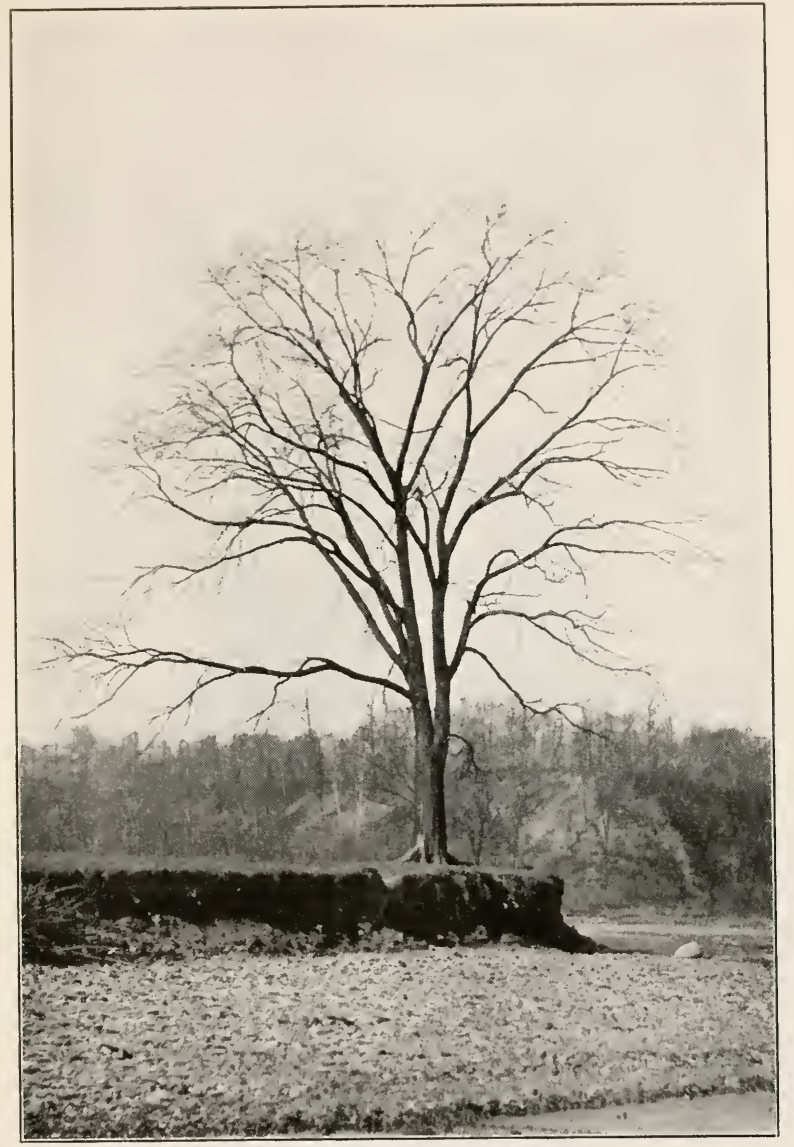

Red Dut Ouircus ribra

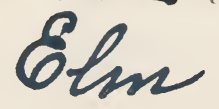



"the afternoons are spacious and the clock ticks slow," but we do not seem to have ten or more consecutive days of this character, such as the early records show and tradition reports.

When the entire extent of forest over eastern North America was laid bare in the course of a single week by the great leaf fall, it may be that there was, by the carpet of dry leaves and the sun's searching rays, a sudden accumulation of heat which showed itself in what was known as the Indian summer. A very pathetic story is told of a party of pioneer Frenchmen in Canada so misled by this unseasonable warmth as to neglect essential arrangements for shelter and protection, only to find themselves in the midst of a destructive blizzard.

In November the wild flowers of the fields indeed shiver by the roadside, but the garden bursts into glory. The Chrysanthemums, white as the snow that is coming, yellow and orange as the sunset, red-varied, deep, glowing, burning red-these stand bearing the Oriental stamp of their Asiatic forebears, out of doors and within, 
showing a riot of color with which no native bloom can compare, and all this as the year is closing.

The days of November are also the days of December until the snows descend and the ice comes; then all the outer defenses have been taken, and the floral year is ended. But-

"The world turns round, distrust it not, Befalls again what once befell; All things return, both sphere and mote, And I shall hear my bluebird's note And dream the dream of Auburn dell."

-Emerson. 


\section{WILD FLOWER SANGTUARIES}

The rapid and continuous disappearance of our early wild flowers is causing the question to arise from many quarters, and in varied tones of interest and anxiety, whether our wild-wood flora, the rarest, the most exquisite, the most ethereal and spirituelle flora on the face of the earth, must, like the Indian and the buffalo, disappear from a world no longer fitted to its needs.

Of course there are fastnesses in the mountains, inaccessible recesses, that will never be forced-and here these nurslings of the forest may make their last stand, but the pleasure is gone that comes to those who wander through woodland ways to catch the first shimmer of bloom on the forest floor, to get the first view of those shy, elusive blossoms which, before the snow has entirely melted and while the trees are still waving leafless branches, bear an unchanging message of life and love. 


\section{WILD FLOWER SANCTUARIES}

Now the question that meets us is - must such flowers as Hepatica, Spring Beauty, Mitella, Dicentra, Trailing Arbutus, and Harbinger of Spring, delicate, wild, and shy, dwelling in the cool, moist recesses of the woodland-must these disappear when the unbroken forest that nourished them has become a memory and the individual trees are dust, or can they be brought back into our lawns and gardens and thrive under our care and protection?

Yes and No. If you have a vision-and by you is meant anybody-a vision of wildlings standing in rows along your garden walk, dismiss it at once. They never will, they will die first. But they will gladly and thankfully come, they will joyfully troop not alone in rows but in companies, if only you will make them a home in which they can live. Their needs are few, but these few are vital: a moist, shaded home, with plenty of humus in the soil and plenty of leaves for a bed-cover. In addition there should be protection from grazing animals and from the man with a rake. Neither sheep, 


\section{WILD FLOWER SANCTUARIES}

horse, nor cow should be allowed to enter a wild flower enclosure. A wood open to grazing animals is not a sanctuary; it is a place of execution. Of all enemies of this rare wild life, the greatest and most implacable is the man with a rake under orders to "tidy up." He is worse than a herd of Jerseys.

One point it seems almost impossible to emphasize enough, and that is the necessity for shade. Since the beginnings of their created time these plants have lived in the shade; an unbroken forest clothed the continent from the Atlantic coast to the prairies of the West. In the spring they swing into the race while the trees are still dormant, and with many the blooming period is past before the forest leaves are mature. Hence, we see that their sunshine is the sunshine of March and April, by the end of May it is gone, and all summer long they live in a green shaded world. These plants can no more bear the direct rays of the summer sun than a white man can live and work in the untempered tropics. Whether it is heat rays or 
actinic rays that kill them, we do not know, but eventually they die.

There are a few exceptions: Bloodroot will flourish by the garden walk and double the size of its leaves. Its bloom, however, is delicate and comes early. The White Violet, likewise, loves the garden walk and abides there. The Mandrake clearly has moved into the open, but moves in companies and still shades its blossoms. The Spring Beauty ventures shyly away from the protecting shade into the full sunlight, but never away from a cool root run.

The time will come, however, when the exquisite pleasure of greeting the firstlings of our flora will be experienced only by those who possess or may visit a wild flower sanctuary. The one perfect and satisfactory way to establish such a retreat is to enclose an area of woodland. This is vital: the groves were the wildlings' homes, and are their only refuge. Fence the field against all grazing animals and let it alone. What care is exercised may be used to 
prevent a too robust growth of bushes and underwood. Encourage Elders and Blackberries within reason-for the birds are the fairies who plant the wildlings, and they follow the lure of the berry. A piece of land with a ledge of rock and a pond or swamp below is ideal. It need not be rich land: many of the plants find their home in the sphagnum sponge of the forest floor. Wondrous results are sometimes obtained by transporting a few bushels of surface earth from another field; also seeds may be scattered and roots transplanted. But one need not be discouraged though space be small; even a small space may have shade, humus, protection. Most wild flowers transplant readily-if one goes forth with a basket and trowel, exercising reasonable care, the little creatures will take the leap safely even in the blooming period, which is the time they are most desired. Many by midsummer have virtually disappeared among the stronger enfolding green, others have lost all their leaves-only retaining their seedpods-still others have wholly disappeared, 
stem and leaf, and the plant has retired to the embrace of mother earth.

There is little to attract in the wild flower garden in midsummer; its supreme moment is April, its life the breath of spring.

I have long hoped that some master of acres would devote a few of them to the cultivation and development of our native Asters. These form a group so beautiful and so vigorous in their wild state that neither gardener nor landscape architect has ever seriously set to work to improve them. Why trouble about it?-they are perfect as they are. It is a case where the wealth of the fields has impoverished the gardens. Now and then one finds an individual plant growing under unusually favorable conditions, and the result is astonishing.

Only two, a real Aster, the New England, and a near Aster, the Boltonia, appear habitually in our gardens-and the fields are full of others quite as beautiful. So far as I know, there has been no effort to enlarge the stars, though Boltonia appears in pink as well as its 


\section{WILD FLOWER SANCTUARIES}

native white. The New England Aster's natural tendency to vary has availed to produce strains of rose and varied purples, but after all little has yet been done and much is possible. Unknown wonders lie within reach of those who will open the waiting doors. 



\section{INDEX OF LATIN NAMES}

Aster, $50 \mathrm{ff}$

Aster acuminatus, $5 \mathrm{I}, 67$

Aster cordifolius, 5I, 52, 72

Aster divaricatus, 5I, 59

Aster ericoides, 65

Aster laevis, 51, 52, 8I

Aster macrophyllus, 5I, 79

Aster multiflorus, 5I, 52, 69

Aster Novæ Angliæ, 50, 53

Aster paniculatus, 5I, 60

Aster patens, 5I, 52, 82

Aster prenanthoides, 51, 52,

74

Aster puniceus, 50, 52, 55

Aster spectabilis, 50,58

Aster Tradescanti, 62

Aster undulatus, 51, 52, 76

BidENS CHRYSANTHEMOIDES, 24

Bidens frondosa, $27 \mathrm{ff}$

COMPOSIte, $5 f f$

EUPATORIUM AGERATOIDES, 88

Falcata comosa, 90

Gentiana ANDREwSil, 100 Gentiana crinita, 97
Gentiana quinquefolia, 103 Gentianaceæ, 97 ff

Gerardia maritima, 96

Gerardia purpurea, 94

Gerardia tenuifolia, 96

Gyrostachys cernua, 107

HamaMelidaCE

Hamamelis Virginiana, I I I

Helenium autumnale, 3I, 33

Helianthus, $9 f f$

Helianthus annuus, 9

Helianthus decapetalus, 12, I 4

Helianthus giganteus, 14 Helianthus grosse-serratus,

I4

Helianthus strumosus, I2, I 4

Helianthus tuberosa, I $5 . f f$ Heliopsis helianthoides, 17 , I 9

Humulus lupulus, 109

LACINARIA SCARIOSA, 84 Leguminoseæ, $90 \mathrm{ff}$ Liatris scariosa, 84

MORACEE, IO9 $f f$ 


\section{INDEX}

Nabalus, $85 \mathrm{ff}$

ORCHIDACE $107 \mathrm{ff}$

Parnassia Caroliniana, IO4

Parnassiaceæ, $\operatorname{10}+f$

RUDBECKIA HIRTA, 3I

Rudbeckia laciniata, 9, 29

SCROPHUlariace $E, 94 f f$

Silphum trifoliatum, 2 I

Solidago, $3+f f$
Solidago bicolor, 4I

Solidago cæsia, 43

Solidago Canadensis, 47

Solidago juncea, 35

Solidago lanceolata, 45

Solidago latifolia, 44

Solidago nemoralis, 38

Solidago rugosa, 37

Solidago sempervirens, 39

Solidago serotina, 46

Spiranthes cernua, 107

VERBESENA HELIANTHOIDES, II 


\section{INDEX OF ENGLISH NAMES}

Aster, Blue IVood, 72 Aster, Dense-Flowered, 69 Aster, Large-Leaved, 79 Aster, Late-Flowering, 82 Aster, New England, 50, 53 Aster, Purple Drift, 74 Aster, Red-Stemmed, 50, 55 Aster, Seaside, $50,5^{8}$ Aster, Smooth-Stem, 8I Aster, Tall White, 5I, 60 Aster, Wavy-Leaved, 76 Aster, IVhite, 51, 62 Aster, White Heath, 5I, 65 Aster, White Mountain, 5I, 67

Aster, White Wood, 5I, 59

Blazing Star, 84

Beggar-Ticks, 27

Black-Eyed Susan, 31

Composite Family, 5, 7, 9

Eupatorium, White, 88

FigwORT FAMILY, 94

Gentian, Closed, ioo Gentian, Five-Flowered, 103 Gentian, Fringed, 97
Gerardia, Purple, 94

Gerardia, Seaside, 96

Gerardia, Slender, 96

Goldenrod, Blue-Stemmed, 43

Goldenrod, Broad-Leaved, 44

Goldenrod, Canadian, 47

Goldenrod, Early, 34

Goldenrod, Field, 38

Goldenrod, Lance-Leaved, 45

Goldenrod, Mid-Season, 46 Goldenrod, Seaside, 39

Goldenrod, White, 4 I Goldenrod, Wrinkle-Leaved, 37

Grass of Parnassus, 104

HoP, WILd, IO9

JERUSALEM ARTICHOKE, I5

Lettuce, White, 85

Lady's Tresses, 107

Mulberry Family, IO9

Orchid Family, 107

Ox-Eye, 17 


\section{INDEX}

Pea Family, 90

Peanut, Wild, 90

Rosin-Weed, Whorled, 2 I

Rudbeckia, Great, 29

SNEEZEWEED, 3 I

Sunflower Family, 9
Sunflower, Brook, 24

Sunflower, Crownbeard, II

Sunflower, Great, 14

Sunflower, Saw-Toothed, 14 Sunflower, Wood, 12

WITCH-HAZEL, I I I 



